UNIVERSIDADE DE SÃO PAULO

FACULDADE DE ECONOMIA, ADMINISTRAÇÃO E CONTABILIDADE DEPARTAMENTO DE ADMINISTRAÇÃO

PROGRAMA DE PÓS-GRADUAÇÃO EM ADMINISTRAÇÃO

\title{
INFLUÊNCIA DA ADOÇÃO DO CARRO FLEX FUEL NA ESTRATÉGIA COMPETITIVA DOS DISTRIBUIDORES DE COMBUSTÍVEIS
}

\author{
Cristina Tosta Santos
}

Orientador: Prof. Dr. Hamilton Luiz Corrêa

SÃO PAULO

2011 
Prof. Dr. João Grandino Rodas

Reitor da Universidade de São Paulo

Prof. Dr. Reinaldo Guerreiro

Diretor da Faculdade de Economia, Administração e Contabilidade

Prof. Dr. Adalberto Américo Fischmann

Chefe do Departamento Administração

Prof. Dr. Lindolfo Galvão de Albuquerque Coordenador do Programa de Pós-Graduação em Administração 


\title{
INFLUÊNCIA DA ADOÇÃO DO CARRO FLEX FUEL NA ESTRATÉGIA COMPETITIVA DOS DISTRIBUIDORES DE COMBUSTÍVEIS
}

\author{
Dissertação de Mestrado apresentada ao \\ Departamento de Administração da Faculdade de \\ Economia, Administração e Contabilidade da \\ Universidade de São Paulo como requisito para \\ obtenção do título de Mestre em Administração.
}

Orientador: Prof. Dr. Hamilton Luiz Corrêa

\author{
Versão Corrigida
}

SÃo PAULO

2011 
Autorizo a reprodução e divulgação total ou parcial deste trabalho, por qualquer meio convencional ou eletrônico, para fins de estudo e pesquisa, desde que citada a fonte.

\section{FICHA CATALOGRÁFICA}

Elaborada pela Seção de Processamento Técnico do SBD/FEA/USP

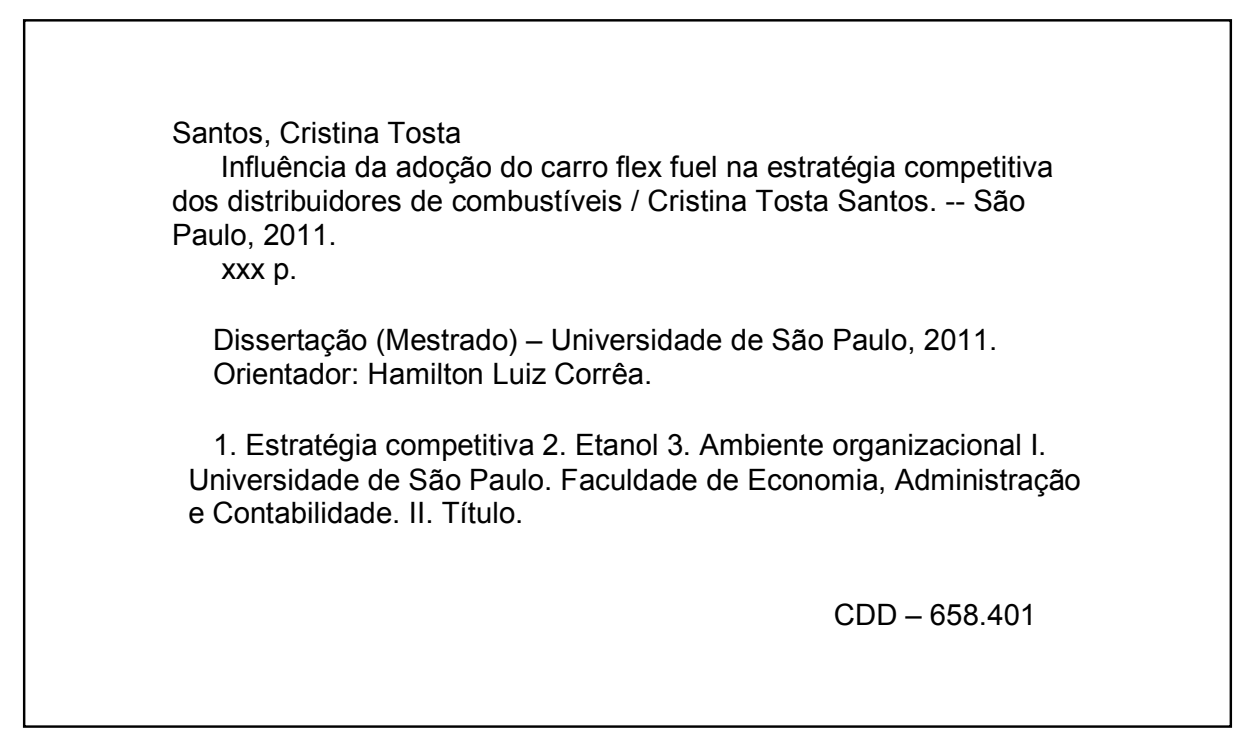


Dedico este trabalho a minha mãe, minha eterna fonte de inspiração. 
Agradeço imensamente a Deus por ter sido o meu sustento em todas as horas difíceis deste caminhar e por ter colocado no meu caminho pessoas maravilhosas que me ajudaram a concluir essa difícil etapa da minha vida.

Com um carinho especial agradeço ao professor Hamilton Luiz Corrêa, meu orientador, que com muita sabedoria e muita paciência me conduziu para a conclusão deste trabalho.

Aos professores Adalberto Fischmann e Martinho Almeida pela plena prontidão e disposição em me ajudar. Sendo eles, para mim, muitas vezes o conforto e a motivação para seguir em frente.

A minha querida mãe por toda ajuda e amor incondicional.

Aos amigos e familiares pela compreensão da minha ausência e distanciamento.

Aos gerentes dos distribuidores de combustíveis pela disponibilidade e todas as informações prestadas. 
Se há algo que salta aos olhos para quem analisa o mercado de combustíveis na primeira década do século XXI são as transformações vivenciadas pelo downstream brasileiro. Foram muitas e profundas. Incluíram mudanças tecnológicas, regulatórias e de mercado. Em alguns casos, definitivas; em outros, os movimentos foram cíclicos. $O$ que não dá para negar é que elas alteraram de maneira significativa o mercado de combustíveis brasileiro.

FECOMBUSTÍVEIS (2011, p.7) 


\section{RESUMO}

$\mathrm{O}$ ambiente dos distribuidores de combustíveis vem sofrendo profundas mudanças nos últimos anos; e este processo pode ser confirmado após análise ambiental utilizando-se do modelo proposto por Almeida (2010). Diante dessa análise, observou-se também que o ambiente dos distribuidores de combustíveis vem avançando para o que D'aveni (1995) denomina como hipercompetitivo. Ademais, a adoção dos carros flex fuel implicou em uma nova dinâmica no setor, exigindo que os distribuidores de combustíveis busquem aplicar novas estratégias competitivas condizentes com a nova realidade ambiental. Com o intuito de explorar as possíveis estratégias competitivas adotadas pelos distribuidores de combustíveis utilizou-se o modelo elaborado por Zaccarelli e Fischmann (1994) por este oferecer maior flexibilidade e ser mais ajustado aos objetivos desta pesquisa. Nesse sentido, o objetivo geral desta pesquisa permeia a identificação das estratégias competitivas adotadas pelos distribuidores de combustíveis para enfrentar as mudanças ambientais influenciadas pela introdução dos carros flex fuel. E para cumprir o objetivo de pesquisa foram entrevistados os gerentes das quatro maiores organizações do setor (BR Distribuidora, Ipiranga, Shell e Esso/Cosan). Juntas, essas empresas perfazem, de acordo com a Agência Nacional de Petróleo Gás Natural e Biocombustíveis (ANP), quase $70 \%$ de todo o volume de combustível automotivo comercializado no país. Como ferramenta de coleta de dados foi utilizada a abordagem de entrevistas semi-estruturadas com o objetivo de ter maior flexibilidade e até mesmo aprofundar informações que poderiam ser relevantes ao tema, mas antes não pensadas ou elaboradas conforme Hair et al (2005). Durante as entrevistas, buscou-se também explorar a percepção e atitudes dos distribuidores sobre a sustentabilidade, tema indispensável ao contexto competitivo atual. Através dos resultados obtidos, pode-se concluir que, de fato, a introdução do veículo flex fuel vem promovendo mudanças na estratégia competitiva dos distribuidores de combustíveis no Brasil. 


\begin{abstract}
The fuel distribution environment has been facing drastic changes in Brazil in the past years. This fact may be affirmed after having carried out an environmental analysis through the employment of a model proposed by Almeida (2010). This analysis also allows one to assert that the environment of fuel distribution has been turning into what D'aveni (1995) denominates hypercompetitive environment. Moreover, the adoption of flex fuel vehicles has imposed new dynamics within the sector. These dynamics have forced fuel distributors to seek new competitive strategies that are in line with the new environmental reality. The model designed by Zaccarelli and Fischmann (1994) was used in this research with the intention to explore the possible competitive strategies adopted by fuel distributors. This model was chosen due to its higher flexibility and to its deeper alignment with the objective of the present research. In this sense, the general objective of this research is to identify the competitive strategies that fuel distributors adopt in order to face and cope with the new environmental changes that have emerged due to the introduction of flex fuel vehicles. In order to achieve this objective, managers of the four largest organizations in the sector have been interviewed. According to the National Agency of Petroleum, Natural Gas and Biofuels (ANP), altogether, these organizations (BR Distribuidora, Ipiranga, Shell and Esso/Cosan) are responsible for nearly $70 \%$ of the volume of automotive fuel traded in the country. As to the data collection tool employed in this thesis, semi-structured interviews were conducted with those managers; this type of interview was selected because it allows for higher flexibility and even for the possibility to investigate issues that could be relevant to the topic but had not been previously thought of or established according to the guidelines given by Hair et al (2005). The interaction during the interviews also aimed at exploring the managers' perception of and attitude towards sustainability, a crucial issue within the competitive current context. The results of the present research allow one to conclude that the introduction of flex fuel vehicles has indeed been promoting major changes in the competitive strategies of fuel distributors in Brazil.
\end{abstract}


SUMÁRIO

1 O PROBLEMA DE PESQUISA 3

1.1 Introdução 3

$\begin{array}{lll}1.2 & \text { Objetivos da pesquisa } & 7\end{array}$

1.3 Definição teórica e conceitos relevantes à pesquisa 7

$\begin{array}{lll}1.4 & \text { Pressupostos conceituais da pesquisa } & 8\end{array}$

$\begin{array}{lll}1.5 & \text { Limitações da pesquisa } & 8\end{array}$

2 FUNDAMENTAÇÃO TEÓRICA 9

2.1 Análise ambiental 9

2.1.1 Macroambiente clima $\quad 13$

$\begin{array}{ll}\text { 2.1.2 Macroambiente solo } & \mathbf{2 5}\end{array}$

2.1.3 Ambiente operacional 35

2.2 Evolução competitiva dos distribuidores de combustíveis 43

$\begin{array}{lll}\text { 2.2.1 Bons e maus competidores } & 57\end{array}$

2.3 Estratégias competitivas $\quad 59$

\begin{tabular}{ll} 
2.3.1 & Estratégia de oportunidades \\
\hline
\end{tabular}

$\begin{array}{ll}\text { 2.3.2 } & \text { Estratégia de desinvestimento }\end{array}$

2.3.3 Estratégia de intento $\quad 62$

$\begin{array}{lll}\text { 2.3.4 } & \text { Estratégia de adaptação } & 63\end{array}$

2.3.5 Estratégia de diferenciação de produto-mercado

2.3.6 Estratégia de diferenciação funcional 66

2.3.7 Estratégia de inovação.

$\begin{array}{lll}\text { 2.3.8 } & \text { Estratégia de evolução } & 71\end{array}$

$\begin{array}{lll}\text { 2.3.9 } & \text { Estratégia de reação } & \mathbf{7 3}\end{array}$

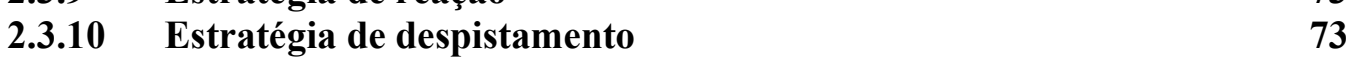

$\begin{array}{ll}\text { 2.3.11 Estratégia de cooperação } & \mathbf{7 4}\end{array}$

$\begin{array}{lll}\text { 2.3.12 Estratégia de agressão } & \mathbf{7 6}\end{array}$

$\begin{array}{ll}\text { 2.3.13 Estratégia autoproteção } & \mathbf{7 6}\end{array}$

$\begin{array}{lll}2.4 & \text { Adoção tecnológica do carro flex fuel } & 77\end{array}$

$\begin{array}{lll}2.5 & \text { Sustentabilidade e responsabilidade social } & \mathbf{8 0}\end{array}$

3 DESCRIÇÃO DA PESQUISA

$\begin{array}{lll}\text { 3.1 Metodologia de pesquisa } & 85\end{array}$

$\begin{array}{lll}3.2 & \text { Universo } & 86\end{array}$

$\begin{array}{lll}\text { 3.3 Amostra da pesquisa } & 86\end{array}$

$\begin{array}{lll}3.4 & \text { Técnicas de coleta, tratamento e análise de dados } & 87\end{array}$

$4 \quad$ APRESENTAÇÃO E ANÁLISE DOS RESULTADOS 89 
4.1 Apresentação dos Distribuidores de Combustíveis 90

4.1.1 BR Distribuidora $\quad 90$

$\begin{array}{lll}\text { 4.1.2 Ipiranga } & 91\end{array}$

$\begin{array}{lll}\text { 4.1.3 Shell } & 91\end{array}$

4.1.4 Esso/Cosan $\quad 92$

4.2 Análise dos Resultados 94

4.2.1 Macroambiente Clima $\quad 94$

$\begin{array}{lr}\text { 4.2.2 Macroambiente Solo } & 97\end{array}$

$\begin{array}{ll}\text { 4.2.3 Ambiente Operacional } & 101\end{array}$

$\begin{array}{lll}\text { 4.3 Estratégias Competitivas } & 103\end{array}$

$\begin{array}{ll}\text { 4.3.1 Apresentação dos resultados } & 105\end{array}$

4.3.2 Análise das estratégias competitivas dos distribuidores de combustíveis 111

$\begin{array}{llr}4.4 & \text { Sustentabilidade } & 121\end{array}$

5 CONSIDERAÇÕES FINAIS $\quad 124$

6 REFERÊNCIA BIBLIOGRÁFICA 131

ANEXO I - RELAÇÃO DE AUTOMÓVEIS COMERCIAIS E LEVES VENDIDOS POR TIPO DE COMBUSTÍVEL. 141

APÊNDICE 1 - PENETRAÇÃO DO ETANOL EM RELAÇÃO A GASOLINA NO PERÍODO DE 2000 A 2009. 


\section{O PROBLEMA DE PESQUISA}

\subsection{Introdução}

As organizações estão inseridas em um ambiente que vem se tornando cada vez mais competitivos (D'aveni, 1995) e as conseqüências desse processo é o surgimento de uma concorrência cada vez mais agressiva, a intensificação das guerras de preços, os ciclos de produtos vêm se tornando cada vez mais curtos, há uma acelerada comoditização dos produtos e serviços como também acentuada redução das margens de lucros. (Porter, 2004; Kim e Mauborgne, 2005; D’aveni, 1995).

Para os distribuidores de combustíveis esse contexto mais competitivo também vem se configurando uma realidade. A desregulamentação do setor de combustíveis trouxe uma nova dinâmica viabilizando inovações, investimentos, desenvolvimento de novas tecnologias, fusões e parcerias em toda a cadeia (Ramos (2006); Maistro (2002); Shikida et al (2004)). O governo decidiu ainda, nesse mesmo período, incentivar a indústria automobilística para o lançamento de uma nova tecnologia automotiva, os carros (motores flex fuel) capazes de funcionar com dois combustíveis (etanol e/ou gasolina) em qualquer proporção de mistura ou exclusividade o que propiciou a retomada do consumo do etanol como combustível substituto à gasolina.

Após a desregulamentação do setor de combustíveis no Brasil e a introdução dos carros flex fuel no mercado se observou o aumento considerável de competidores pela inserção de novos distribuidores denominados independentes e de postos denominados bandeiras brancas (Nunes e Gomes, 2005). O surgimento desses novos agentes favoreceu uma divisão entre bons e maus competidores (Porter, 2004) estimulados principalmente, por brechas de caráter fiscal, tributário e regulatório (Dalmonech et al, 2005; Fecombustíveis, 2011); resultando um ambiente altamente competitivo (D'aveni, 1995). 
Contudo, a cada novo ano, depois do lançamento dos carros flex fuel, o volume de etanol consumido no país batia novos recordes de vendas e em 2008, um marco na história desse produto ${ }^{1}$, pois superou o volume consumido de gasolinas no país.

O conjunto desses eventos propiciou mudanças significativas resultando em um mercado fortemente concentrado. Em 2008, dois gigantes distribuidores internacionais decidiram sair do país e venderam suas operações para empresas locais: a Texaco (Chevron) e a Esso (Exxon Mobil). Ipiranga assumiu as operações da Texaco e a Cosan - uma das maiores produtoras de produtos derivados da cana-de-açúcar - compra as operações da Esso no Brasil. Em 2010, o mercado termina ainda mais concentrado com a formação da joint venture entre a Esso/Cosan e a Shell.

Nesse contexto o Brasil nas últimas décadas promoveu melhorias significativas na qualidade de vida da população, havendo avanços nas áreas de educação, saúde, distribuição de renda e maior desenvolvimento das regiões Norte, Nordeste e CentroOeste do país; se observou maior presença das mulheres no mercado de trabalho como também o crescimento do número de família que são chefiadas por mulheres (IPEA).

Essas mudanças de caráter sócio-econômico da população favorecem novas oportunidades e novos desafios para as organizações. (Kotler e Caslione, 2009)

O ponto positivo é que os distribuidores de combustíveis pesquisados estão sediados no país há muitas décadas e puderam observar essas transformações da sociedade e nesse sentido buscar se adaptar as novas exigências dos seus clientes e consumidores. Assim como também buscar atender as novas demandas emergentes de um ambiente que apresenta mudanças em um ritmo acelerado.

Considerando esses fatores, Brown e Eisenhardt (1998) reforçam que o ambiente no qual as organizações estão inseridas são incertos, complexos e caóticos. E para sobreviver a este contexto é necessário desenvolver habilidades para o gerenciamento das mudanças ambientais.

\footnotetext{
${ }^{1}$ Fonte: ANP. Se considerando o volume total do produto (anidro e hidratado). Anidro é adicionado às gasolinas e hidratado comercializado diretamente para o consumidor final.
} 
Para Aaker (2007) a importância da análise ambiental é crescente, pois torna possível conhecer as tendências e os fatores que possam afetar a estratégia organizacional seja de maneira direta ou indiretamente. Almeida (2010. p.11) define o ambiente de uma organização como "tudo aquilo que influencia o seu desempenho sem que ela pouco ou nada possa fazer para mudar tais fatores ou variáveis". E para melhor compreender o ambiente das organizações o autor propõe o modelo de análise ambiental resumidos em quatro dimensões: Macroambiente Clima (1), Macroambiente Solo (2), Ambiente Operacional (3) e Ambiente Interno (4). Sendo este modelo escolhido para analisar o ambiente dos distribuidores de combustíveis nesta pesquisa.

Ao observar e confirmar as mudanças ocorridas no ambiente dos distribuidores de combustíveis, nestes últimos anos, após aplicação do modelo proposto por Almeida (2010) o problema de pesquisa foi estabelecido.

E sendo assim, o problema dessa pesquisa está fundamentado na corrente teórica que considera que as estratégias competitivas das organizações são influenciadas pelo ambiente do qual estão inseridas (Almeida e Almeida, 2003). Nesse pensamento, passou-se a questionar: qual influencia da adoção do carro flex fuel na estratégia competitiva dos distribuidores de combustíveis?

Deve-se considerar que a estratégia competitiva está relacionada ao enfoque e o modo como as organizações competem para ter sucesso em um determinado negócio Ansoff (1990). Costa (2007) enfatiza que as estratégias competitivas são ferramentas utilizadas pelas organizações quando há disputa entre o mesmo público-alvo, mesmo mercado, compradores ou consumidores; essas estratégias podem ser utilizadas de forma explícita ou implícita.

Para identificar as possíveis estratégias utilizadas pelos distribuidores de combustíveis, no período de 2000 a 2009, foram adotadas as treze estratégias competitivas diagnosticas por Zaccarelli e Fischmann (1994). São elas: oportunidades (1), desinvestimentos (2), intento (3), Adaptação (4), diferenciação de produto-mercado (5), diferenciação funcional (6), Inovação (7), Evolução (8), Reação (9), Despistamento 
(10), Cooperação (11), Agressão (12) e Autoproteção (13). A escolha e a aplicação deste modelo se justificam diante da maior flexibilidade e amplitude.

Com o objetivo de seguir o plano de pesquisa proposto por Hair et al (2005) foram realizadas sessões de entrevistas conversacionais livres como define Godói (2006) com revendedores de combustíveis nas cidades de São Paulo, Osasco, Barueri e Campinas. Essa etapa foi importante e necessária, pois permitiu ao pesquisador conhecer melhor e explorar as mudanças no ambiente a partir da visão e percepção dos clientes dos distribuidores de combustíveis. A escolha dessas cidades foi conveniência do autor não havendo nenhum critério pré-estabelecido inicialmente.

Como ferramenta de coleta de dados foi utilizada a abordagem de entrevistas semiestruturada. Foram entrevistados os gerentes das quatro maiores organizações do setor (BR Distribuidora, Ipiranga Shell e Esso/Cosan), que juntas perfazem, de acordo, com a ANP - Agência Nacional de Petróleo, em 2009, quase 70\% de todo o volume de combustível automotivo comercializado no país. As entrevistas semi-estruturada favoreceram maior flexibilidade e até mesmo aprofundamento de informações que foram relevantes ao tema, mas que antes não haviam sido pensadas ou elaboradas, conforme define Hair et al (2005). Buscou-se também durante a entrevista explorar a percepção e atitudes dos distribuidores sobre a sustentabilidade, tema indispensável ao contexto competitivo atual.

Esta é uma pesquisa qualitativa que assume um caráter explorário conforme Gil (2008). Está fundamentada no método indutivo, como descreve Sampieri et al (2006), esse método se propõe a explorar e descrever uma realidade particular e gerar perspectivas teóricas.

Diante dos resultados obtidos pelas entrevistas chegou-se a conclusão que o carro flex fuel influenciou de alguma maneira mudanças nas estratégias competitivas dos distribuidores de combustíveis durante o período pesquisado. Reforçou também a corrente teórica que considera que as organizações recebem influência do ambiente e buscam adaptar-se aos novos contextos e demandas desse ambiente. 


\subsection{Objetivos da pesquisa}

O objetivo geral da pesquisa é identificar as estratégias competitivas adotadas pelos distribuidores de combustíveis para enfrentar as mudanças ambientais influenciadas pela introdução dos carros flex fuel. Os objetivos específicos podem ser descritos como:

- Identificar as mudanças no ambiente dos distribuidores de combustíveis no período de 2003 a 2009.

- Verificar a atuação dos distribuidores de combustíveis frente às mudanças ambientais no período de 2003 a 2009

\subsection{Definição teórica e conceitos relevantes à pesquisa}

A seguir serão definidos os principais termos relevantes para a compreensão da pesquisa:

- Influência: É a capacidade de um agente " $\mathrm{x}$ " modificar, transformar, inovar ou até mesmo reformular "y”. Uma relação causal (se x então y).

- Adoção: Adoção do carro de motores flex fuel pelos usuários de veículos leves e de passeio. Como medida será observada a evolução da participação destes veículos na frota nacional total de veículos leves e de passeio.

- Motores flex fuel: veículos que funcionam com mais de um combustível automotivo em qualquer proporção e/ou exclusivamente, sendo que um deles é considerado biocombustível, ou seja, não fóssil (etanol, eletricidade). Neste estudo, serão considerados exclusivamente carros projetados para rodar com etanol e/ou gasolina.

- Estratégia Competitiva: Ansoff, 1990 apresenta uma clara diferenciação entre estratégia e estratégia competitiva. Para o autor a "Estratégia é um dos vários conjuntos de regras de decisão para orientar o comportamento de uma organização" (Ansoff, 1990. p. 95). E a estratégia competitiva “especifica o enfoque especial que a empresa tentará utilizar para ter 
sucesso em cada um das áreas estratégicas do negócio”. (Ansoff, 1990. p. 102).

- Distribuidores de combustíveis: A ANP os define como sendo "agente cuja atividade caracteriza-se pela aquisição de produtos a granel e sua revenda a granel (por atacado) para a rede varejista ou grandes consumidores."

\subsection{Pressupostos Conceituais da Pesquisa}

- O etanol favoreceu aumento do número de competidores e, por sua vez, proporcionou maior competição entre os distribuidores. (Nunes e Gomes, 2005).

- As organizações são influenciadas pelo ambiente do qual estão inseridas. (Almeida e Almeida, 2003).

\subsection{Limitações da Pesquisa}

De acordo com a metodologia adotada não será possível generalizar as conclusões obtidas como resultado desta pesquisa.

As conclusões serão baseadas nas opiniões dos gerentes das empresas entrevistadas, podendo, por conseguinte, estar influenciadas pela área de atuação, tempo que ocupa o cargo e experiências anteriores.

Eventualmente, diante das respostas obtidas pelos entrevistados não foi possível chegar às conclusões desejadas. 


\section{FUNDAMENTAÇÃO TEÓRICA}

É inegável que as empresas de hoje estão submersas a um ambiente muito mais dinâmico e competitivo quando comparado com décadas anteriores ( $\mathrm{D}^{\prime}$ Avenni, 1995). Este cenário se deve principalmente ao processo de globalização, ao ritmo acelerado das inovações e os rápidos avanços tecnológicos em todas as áreas. (Kotler e Caslione, 2009).

Essa é uma das razões pela qual a análise ambiental vem ganhando mais espaço e atenção durante o processo do planejamento estratégico. Para compreender o ambiente dos distribuidores de combustíveis foi adotado o modelo de análise ambiental proposto por Almeida (2010). Considerando ainda que as mudanças do ambiente influenciem as organizações como afirmam Almeida e Almeida (2003), assim como Aaker (2007) serão analisadas as estratégias competitivas adotadas pelos distribuidores de combustíveis ao longo do período pesquisado do ano de 2000 ao ano de 2009, através do modelo proposto por Zaccarelli e Fischmann (1994) por apresentar maior amplitude e flexibilidade.

A fundamentação teórica desta pesquisa foi dividida em cinco subcapítulos: (2.1) análise ambiental e a descrição das dimensões ambientais; (2.2) evolução do cenário competitivo dos distribuidores de combustíveis; (2.3) revisão das estratégias competitivas; e, por fim, será discutido o papel da (2.5) sustentabilidade para os distribuidores de combustíveis por ser um tema indispensável ao contexto competitivo atual.

\subsection{Análise ambiental}

A análise ambiental é uma das atividades do planejamento estratégico que tem por objetivo guiar as organizações no presente e para o futuro. Pode certamente facilitar uma melhor compreensão das diversas forças que exercem influências dentro e fora das 
organizações assim como também auxiliá-las na prospecção de tendências futuras. Almeida (2010. p.11) define o ambiente de uma organização como "tudo aquilo que influencia o seu desempenho sem que ela pouco ou nada possa fazer para mudar tais fatores ou variáveis." Vale salientar que a análise ambiental é decorrente da Teoria Geral dos Sistemas que parte do princípio que a organização é o todo e não o conjunto de partes isoladas. A análise ambiental acredita que as organizações são sistemas abertos e recebem influência do ambiente onde estão inseridas (Almeida e Almeida, 2003). Deve-se compreender como sistemas abertos um processo dinâmico de troca de informações durante todo o "circuito" do sistema (entradas (recursos), transformação (processos) e saída (produto ou serviços) e retroalimentação.

Aaker (2007) enfatiza a importância da análise ambiental por acreditar que é possível conhecer as tendências e os fatores que possam afetar a estratégia organizacional seja de maneira direta ou indiretamente. Neste mesmo pensamento, Almeida (2010) afirma que a análise ambiental é uma das etapas mais importantes do planejamento estratégico, uma vez que, as organizações passam a conhecer as oportunidades e ameaças do ambiente o que permitiria a estas alcançar a eficácia.

De acordo com Almeida e Oliva (2001), Philip Kotler é considerado um dos pioneiros na classificação ambiental. Kotler e Armstrog (2007) descrevem em seu livro que o ambiente de marketing é formado per seis principais forças. Os autores descrevem essas forças como:

1. Demográficas: estudos sobre a demografia da população humana (sexo, idade, densidade, localização, etc).

2. Econômicas: fatores que provocam mudanças no padrão de compra e de gastos das pessoas.

3. Naturais: os recursos naturais (insumos e matéria - prima)

4. Tecnológicas: tecnologias generalizadas.

5. Políticas: são as leis, órgãos governamentais e grupos de pressão que influenciam ou limitam as organizações.

6. Culturais: são as percepções, preferências e valores de uma sociedade. 
Apesar do foco destes autores centrarem nas questões de marketing os estudos preliminares deles permitiram a expansão do pensamento e vários autores desenvolveram modelos que objetivam uma análise ambiental.

Sendo assim, Certo et al (2005) acreditam que a análise ambiental podem assumir três papéis fundamentais - orientação para a política(1), orientação para o planejamento estratégico integrado(2) e por fim orientação para a função (3). A orientação para a política visa antecipação e adequação de possíveis leis ou normas que possam afetar a organização de alguma maneira. A orientação para o planejamento estratégico integrado tem o objetivo melhorar o desempenho da organização através da sensibilização do alto escalão e corpo gerencial com as questões que surgem no ambiente. Já a orientação para a função tem o objetivo de melhorar o desempenho de um setor, departamento ou unidade de negócio.

Os autores complementam que a análise ambiental compreende três dimensões: o Geral (1) para todas as organizações (forças macroeconômicas, características da sociedade, ambiente político/legal e tecnológico), Operacional (2) (ambiente que se dá a concorrência e disputas - clientes, fornecedores, mão- de- obra, questões internacionais, etc.) e o Interno (3) (ambiente organizacional único e próprio da organização)

Aaker (2007) propõe uma divisão de 5 dimensões para a análise ambiental: Tecnológica (1) (tecnologias existentes e futuras), Governamental (2), (cenários político - legislação, impostos, taxas, etc), Econômica (3) (fatores macroeconômicos inflação, PIB, etc.), Cultural (4) (tendências e emergentes e atuais no estilo de vida) Demográfica (5) (tendências demográficas).

Para Porter (2004) existem cinco ameaças inerentes ao ambiente competitivo da indústria: entrantes potenciais, compradores, fornecedores, intensidade da rivalidade, produtos e serviços substitutos. Para compreender a influência dessas ameaças competitivas, o autor faz uso da análise SWOT com o objetivo de compreender o ambiente interno e externo à organização (interno: forças e fraquezas; externos: oportunidades e ameaças). A escolha das dimensões será inerente ao setor como também o estágio competitivo da indústria. 
Já Almeida (2010) propõe o modelo de análise ambiental em 4 dimensões: macroambiente, clima (1) (variáveis decorrentes da decisão do poder político), macroambiente, solo (2) (características populacionais), ambiente operacional (3) (concorrentes, fornecedores e clientes) e ambiente interno (4) (proprietários e funcionários). É possível observar (Quadro 1) com o resumo do pensamento do autor e as respectivas definições, variáveis e o método de análise de cada uma das dimensões propostas.

Quadro 1 - Segmentação Ambiental de acordo com Almeida (2010)

\begin{tabular}{|l|c|c|c|}
\hline \multicolumn{1}{|c|}{$\begin{array}{c}\text { Segmentação } \\
\text { Ambiental }\end{array}$} & Variáveis Ambientais & Características & Método de Análise \\
\hline $\begin{array}{l}\text { Macroambiente } \\
\text { Clima }\end{array}$ & $\begin{array}{c}\text { São as variáveis } \\
\text { decorrentes do poder } \\
\text { político, legal e } \\
\text { econômico. }\end{array}$ & $\begin{array}{c}\text { Difícil de ser previsto a } \\
\text { curto prazo, mas possível } \\
\text { de se projetar tendências a } \\
\text { longo prazo. }\end{array}$ & $\begin{array}{c}\text { Através de } \\
\text { especialistas. }\end{array}$ \\
\hline $\begin{array}{l}\text { Macroambiente } \\
\text { Solo }\end{array}$ & $\begin{array}{c}\text { São variáveis do futuro } \\
\text { da população e suas } \\
\text { características. }\end{array}$ & Previsíveis e precisas. & Estudos estatísticos \\
\hline $\begin{array}{l}\text { Ambiente } \\
\text { Operacional }\end{array}$ & $\begin{array}{c}\text { Concorrentes, } \\
\text { fornecedores e clientes } \\
\text { diretos. }\end{array}$ & $\begin{array}{c}\text { Previsões são feitas levando } \\
\text { em consideração a evolução } \\
\text { tecnológica. }\end{array}$ & $\begin{array}{c}\text { Estudo de cenários para } \\
\text { identificar o } \\
\text { relacionamento } \\
\text { operacional futuro. }\end{array}$ \\
\hline $\begin{array}{l}\text { Ambiente } \\
\text { Interno }\end{array}$ & $\begin{array}{c}\text { Valores e aspirações das } \\
\text { pessoas (proprietários e } \\
\text { funcionários) }\end{array}$ & $\begin{array}{c}\text { As empresas tendem } \\
\text { agrupam as pessoas com } \\
\text { valores semelhantes. }\end{array}$ & $\begin{array}{c}\text { Através do sistema de } \\
\text { análise da cultura } \\
\text { organizacional. }\end{array}$ \\
\hline
\end{tabular}

Fonte: Almeida (2010. p. 14)

Um ponto a ser esclarecido é que a análise ambiental nesta pesquisa não tem o objetivo de construir um planejamento estratégico dos distribuidores de combustíveis. E por isso, o ambiente interno foi excluído da análise com a intenção de se manter fiel aos objetivos propostos nesta pesquisa e assim delimitar e direcionar esforços.

Especificamente para o Macroambiente Clima, Almeida (2010) recomenda como método de análise para essa dimensão ouvir a opinião de especialistas, o que não faz sentido, para esta pesquisa, uma vez que se tem o objetivo de analisar um período passado e serão através dos resultados que se buscará demonstrar a relação entre elas. 
Para o Macroambiente Solo, será pontuado algumas das principais mudanças na estrutura da população brasileira que foram mais significativas e que possam representar alguma relação lógica com o setor. Como, por exemplo, o desenvolvimento da classe média brasileira e a quantidade total de veículos circulando no país. Como método de análise será utilizado os relatórios do Instituto Brasileiro de Geografia e Estatística (IBGE), principalmente.

No ambiente operacional buscar-se-á compreender as mudanças no âmbito dos competidores, fornecedores e clientes e a influência da introdução do carro flex fuel para os distribuidores de combustíveis.

\subsubsection{Macroambiente clima}

Almeida (1997) descreve as variáveis do macroambiente clima como "variáveis decorrentes do poder político". Podem ser definidos como variáveis a legislação tributária, restrições de importação e ainda perspectivas/cenários econômicos. Almeida (2010) salienta que essas decisões do poder político podem ser das esferas municipais, estaduais, federais ou até mesmo a legislação de outros países que possa implicar em algum tipo de restrição. O autor (2010) afirma também que o Macroambiente Clima é difícil prevê, principalmente, a longo prazo, em muitos casos é necessário contar com apoio de especialistas para projetar tendências futuras. Por outro lado, é possível afirmar que as organizações que desenvolvem a habilidade de prevê e antecipar as tendências deste ambiente poderão capitalizar oportunidades que poderão permitir algum tipo de vantagem competitiva frente à concorrência (Dibb, 1996).

Almeida (2010) recomenda também uma análise nas variáveis macroeconômicas. Não há dúvida entre os especialistas sobre a influência dos índices macroeconômicos como PIB, inflação, taxa de desemprego, juros, saldo da balança comercial, entre outros exercem algum tipo de influência sobre as organizações. Sachs e Larrain (2000) afirmam que ao observar essas variáveis, é possível, compreender e comparar a evolução da economia assim como prever tendências. Ducan e Ginter (1990) salientam 
ainda que quanto maior o conhecimento sobre as variáveis macroeconômicas e de que forma estão intrinsecamente conectadas, maior é a conscientização gerencial durante o processo de planejamento estratégico. Para o Macroambiente Clima dos distribuidores de combustíveis serão relacionadas as principais decisões governamentais no período pesquisado que tenha alguma relação com o setor.

E, nesse sentido, observa-se que para o setor de combustíveis o governo foi o grande responsável pela promoção do etanol como produto aditivo à gasolina (etanol anidro) e substituto (etanol hidratado) da gasolina ao longo dos anos. Para isso, utilizou de todos os recursos possíveis para promover ou frear o consumo destes combustíveis quando assim foi conveniente. Os fatores que motivaram essa decisão entre outras possíveis variáveis tem forte correlação com fatores externos; como, por exemplo, a variação do preço internacional do barril de petróleo e/ou o preço internacional da saca de açúcar.

As décadas de 1970 e 1980 foram marcadas por forte alta no preço do barril do petróleo. O que motivou o governo a buscar alternativas para diminuir o gasto público com a importação da commodity e este contexto favoreceu o desenvolvimento tecnológico do etanol como combustível substituto à gasolina. $\mathrm{O}$ programa foi bem sucedido até o momento em que o preço do barril do petróleo retomou patamares anteriores aos verificados durante a crise do Oriente Médio (iniciado na década de 1970). Com a gasolina a preços mais competitivos que o etanol, a eliminação dos subsídios governamentais dados da época, aos poucos, o etanol foi perdendo espaço até a venda se tornar insignificante no início da década de 1990.

Já o açúcar quando este produto remunerava melhor produtor do que o etanol, seja no mercado interno ou mercado externo parte da safra era desviada para produção do açúcar e isso ocasionava e ocasiona ainda hoje redução da oferta dos etanóis (anidro e hidratado), aumentando assim o preço da gasolina e / ou etanol hidratado para o consumidor final. Aos distribuidores assim como os postos de combustíveis (revenda) e os próprios consumidores tiveram que se adaptar aos ciclos destes produtos e pagar a conta.

É importante lembrar que o governo vem estabelecendo quotas máximas para produção de açúcar para as usinas capazes de produzir os dois produtos na mesma planta. Mas, 
percentual de cana-de-açúcar destinado a produção do açúcar e etanóis variaram de acordo com a demanda interna e o cenário internacional de preços destas commodities.

Ramos (2006) relata algumas das principais decisões promovidas pelo governo através de leis ou decretos, em relação, ao setor de combustíveis, nos últimos 20 anos, promoveram profundas transformações nos anos seguintes:

- Até 1999, os produtores de etanol tinham garantia do preço e da compra da produção. A Petrobras, neste período, era responsável pela compra, estocagem, mistura do etanol anidro nas gasolinas assim como também a venda do etanol hidratado para os distribuidores de combustíveis. Após esse período, o governo passa a realizar compras através de leilões e em um segundo momento as distribuidoras passam a ser responsáveis pela compra, pela adição do etanol anidro na gasolina assim como também pela compra, estocagem e a comercialização do etanol hidratado inclusive.

- Através da Portaria n. ${ }^{\circ} 64$ de 1996, os preços da gasolina e do etanol passam a ser regulados pelo mercado. Vale salientar que esta portaria passou a vigorar para o etanol anidro em 1997 e para o etanol hidratado em 1999. Ramos (2006) destaca que essa medida governamental acarretou no fechamento de 28 unidades produtoras do etanol, na concentração da produção (fusão, compra e aquisição entre usinas) e forte injeção de capital estrangeiro no setor.

- Em 1997, o governo cria a ANP - Agência Nacional do Petróleo, Gás Natural e Biocombustíveis que passaria a ser responsável pela fiscalização e regulamentação do setor.

- Até 2002, então, o setor de combustíveis tinha formação de preços considerado um sistema misto, ou seja, os preços entre as usinas e os distribuidores eram regulados pelo governo; e os preços entre os distribuidores e os postos de combustíveis eram liberados. Os preços só se tornam livres em toda a cadeia (do produtor ao consumidor final) no ano de 2002. (Maistro, 2002).

- Através da Lei n. ${ }^{\circ} 9.660$ de 1998, o governo determina que os veículos dos governos e municípios sejam movidos a etanol. 
- Em 2001, através da Lei n. ${ }^{0} 10.336$, implementou a CIDE Contribuição de Intervenção no Domínio Econômico sobre a importação e a comercialização de petróleo e seus derivados, gás natural e seus derivados como também o etanol etílico e combustível.

- Coordenação entre governo e ANFAVEA - Associação Nacional dos Fabricantes de Veículos Automotores lança no mercado, em 2003, o carro flex fuel. Veículos projetados para rodar com etanol hidratado e/ou gasolina em qualquer proporção.

- Redução do ICMS para o etanol hidratado. Em 2003, O estado de São Paulo passou a ter a menor alíquota do imposto no país com $12 \%$ enquanto os demais estados variam entre $18 \%$ a $29 \%$.

- Redução do IPI - Imposto Sobre Produtos Industrializados para compra de veículos leves e de passeio. Modelos de 1.0 tiveram redução de $7 \%$ para $3 \%$ e modelos 2.0 de $11 \%$ para $7,5 \%$ entre dezembro de 2008 a março de 2010. (Maistro, 2002).

Shikida et al (2004) afirmam que o processo de desregulamentação do setor trouxe uma nova dinâmica para toda a cadeia da cana-de-açúcar e "os que não se adaptaram aos novos tempos enfrentaram dificuldades de sobrevivência no ambiente competitivo, principalmente, quando se considera que o estado não é mais o credor em última instância" (Shikida et al 2004. p.380). Ainda para os autores, o fato de o governo ter garantido quotas de produção (reserva de mercado), fixado de preços para a cana-deaçúcar, açúcar e etanol (garantindo de margens para o produtor e distribuidor) além de outros subsídios colocou, os produtores, principalmente, em uma zona de conforto do qual não estimulava melhorias tecnológicas, por exemplo. A desregulamentação fez emergir um novo paradigma para toda a cadeia no que tange a necessidade de autogestão e esse novo cenário gerou uma busca por melhorias significativas na eficiência em toda a cadeia, por desenvolvimento de novos produtos e por novos nichos de mercados.

Para compreender o impacto desse processo Ramos (2006) destaca que até 1996, existiam 320 unidades produtoras de açúcar e de etanol, durante o processo de desregulamentação foram fechadas 28 unidades por não serem capazes de sobreviver 
no ambiente mais competitivo. Além disso, houve uma grande redução do número de destilarias autônomas, de 170 para 50 antes e depois do processo de desregulamentação. Esse evento pode ser explicado também pela forte concentração da produção ocorrida entre os anos de 2000 e 2002; de acordo com a autora, muitas fusões e incorporações foram realizadas neste mesmo período, a fim de ilustrar pelo menos 40 unidades produtoras passaram a pertencer um único grupo - COSAN. Vale lembrar também que no mesmo período foi observada a entrada de grupos estrangeiros que passaram investir no setor.

Ramos (2006) destaca ainda que o novo contexto competitivo encadeou a necessidade de redução dos custos e elevação da produtividade. Essa necessidade emergente propiciou o desenvolvimento de novas variedades de canas tornando mais eficiente o desenvolvimento de novos métodos e técnicas agrícolas. O período foi marcado também pela introdução da mecanização das lavouras, com o objetivo de se adequar a implementação do Decreto Estadual n. ${ }^{0} 42.056$ de 1997 criou-se um calendário para eliminar a queima da cana-de-açúcar.

No que tange aos distribuidores de combustíveis se percebe um aumento considerável do número de competidores principalmente nos anos de 2003 a 2005. O ano de 2002 se encerra com 151 distribuidores de etanol e 169 de gasolina. No ano de 2003 e 2004 há um crescimento de $6 \%$ em cada ano, em relação ao ano de 2002. Já o ano de 2004 se encerra com 170 distribuidores de etanol e 171 distribuidores de gasolina, porém foram os distribuidores de etanol que apresentaram um forte crescimento nesse período, se comparado com o ano de 2002 apresentando um crescimento superior de 11\%. Somente no ano de 2005 em diante, observa-se uma queda no número dos distribuidores, principalmente, de etanol que apresenta maiores perdas ao longo dos próximos anos. Através da (Tabela 1) é possível acompanhar a evolução do número de distribuidores de combustíveis ao longo do período de 2002 a 2009.

\begin{tabular}{lcccccccccc}
\multicolumn{1}{c}{ Tabela 1 } & Evolução do número de distribuidores de combustíveis por produto no Brasil. \\
Ano & $\mathbf{2 0 0 0}$ & $\mathbf{2 0 0 1}$ & $\mathbf{2 0 0 2}$ & $\mathbf{2 0 0 3}$ & $\mathbf{2 0 0 4}$ & $\mathbf{2 0 0 5}$ & $\mathbf{2 0 0 6}$ & $\mathbf{2 0 0 7}$ & $\mathbf{2 0 0 8}$ & $\mathbf{2 0 0 9}$ \\
Etanol & 165 & 157 & 151 & 159 & 170 & 163 & 154 & 159 & 157 & 154 \\
Gasolina & 160 & 163 & 169 & 180 & 171 & 165 & 136 & 159 & 159 & 140
\end{tabular}
Fonte: ANP. 
Por outro lado, verificou-se ao longo dos anos que o mercado de distribuição de combustíveis caminhou para uma concentração de mercado, exatamente como ocorreu no "campo". ALE adquiriu a rede de postos da Repsol e a rede Polipetro, que posteriormente, em 2006, se fundiu com SAT formando o grupo ALESAT. Em 2007, o Grupo Ultra, assumiu as bases de distribuição e os postos de combustíveis da IPIRANGA nas regiões Sul e Sudeste, enquanto a Petrobrás se tornou responsável pelas demais regiões do país. Além disso, duas grandes multinacionais do setor decidiram vender suas participações no Brasil para empresas locais; em 2008, a Texaco (Chevron) é vendida para o Grupo Ultra/ IPIRANGA e no mesmo ano a Esso (Exxon Mobil) anuncia a venda de suas operações no país para a Cosan. Um ano e meio depois, a Cosan, formaliza a joint venture com Shell. (Fecombustíveis, 2011).

A Fecombustíveis (2011) relembra que o período de 2002 a 2005 foi marcado também por diversos atos ilícitos promovidos por agentes de todas as partes da cadeia que encontraram algum tipo de fragilidade no sistema fiscal, tributário e/ou regulatório. Neste contexto, foi observada a adição de solventes, água, metanol, além de mecanismos utilizados para enganar a fiscalização como um dispositivo escondido e quando acionado liberava produtos em conformidade com as exigências legais; saindo da fiscalização voltavam a comercializar tais produtos fora da especificação determinada pela a ANP. Além disso, a sonegação de impostos, principalmente o etanol considerado outro agravante intrinsecamente relacionado com a venda direta dos combustíveis das usinas para postos de combustíveis ou até mesmo a comercialização dos produtos sem a emissão da nota físcal. De acordo com a Fecombustíveis (2011) a estimativa é prejuízo de $\mathrm{R} \$ 1$ bilhão por ano nos cofres públicos.

Esse cenário pode ser um fator que tenha exercido alguma contribuição para o aumento significativo de novos distribuidores de etanol, também se observa que o governo passou a conhecer e a adotar medidas para eliminar esses atos ilegais. Observou-se em contrapartida, uma redução da quantidade de distribuidores de combustíveis, como se pode observar na (Tabela 1) entre 2005 e 2006 houve uma queda de quase $12 \%$ no número de distribuidores. O governo criou estratégias para eliminar esses atos ilícitos. 
Percebendo a fragilidade do sistema ao longo dos anos o governo foi buscando maneiras de eliminar esses atos ilegais.

Durante o período de liberação dos preços foi realizada reforma tributária resultando na criação da CIDE que passou a dar base legal e tributária para a importação e comercialização dos combustíveis. A ANP regulamentou a utilização de um corante no etanol anidro, em 2006, dificultando assim a prática de adicionar água ao produto.

Já a Fecombustíveis (2011) acredita que as principais medidas foram a Lei $n .^{\circ} 11.929$ de 2005 prevê a cassação da inscrição estadual do contribuinte que adquirir, transportar, estocar ou comercializar combustíveis fora da especificação determinada pela ANP. Outra lei também citada pelo órgão como essencial ao combate a ilegalidade foi a Lei n.o 12.675 de 2007 que estabelece o perdimento do produto assim como também interdição temporária ou definitiva do estabelecimento. Não menos importante também foi a Lei da Nota Fiscal Eletrônica executada pelo estado de São Paulo inicialmente, mas já copiada por outros estados por ter se mostrado bastante eficiente no combate a sonegação fiscal.

É possível afirmar que o governo juntamente com sindicatos e outras instituições que tem o interesse em promover um mercado livre de atos ilegais vem atuando de maneira enérgica e positiva, para eliminar as fontes e atos ilegais praticados até então. .

Outra mudança no âmbito tributário extremamente importante para o setor foi a decisão do governo Estadual de São Paulo em reduzir a alíquota do ICMS no etanol de 25\% pra $12 \%$ no ano de 2003, mesmo ano de lançamento dos carros flex fuel objetivando a redução do preço ao consumidor final, e, por fim, incentivar o setor sucroalcooleiro que tem grande representatividade econômica no Estado. Outros Estados mais tarde tomaram medida semelhante, mas nenhum outro Estado obteve uma redução tão significativa quanto São Paulo. O Estado de Goiás de 26\% para 20\%, Minas Gerais reduziu de $25 \%$ para $22 \%$, Rio Grande do Sul de $29 \%$ para $25 \%$, Pará de $28 \%$ para $26 \%$, entre outros.

A situação atual das alíquotas do ICMS para etanol por Estado, de acordo com a Fecombustíveis (2011), está demonstrada na (Ilustração 1). Em resumo, as regiões 
Norte, Nordeste e Centro-Oeste adotaram alíquota de 25\%, com exceção dos Estados do Alagoas e Sergipe, ambos, com 27\%, Pará com 26\%, Goiás com 20\% e a Bahia perfazendo a menor alíquota da região com 19\%. A região Sul e Sudeste, apenas três Estados com 25\% - Minas Gerais, Rio Grande do Sul e Santa Catarina. O Estado do Espírito Santo tem a maior alíquota da região com $27 \%$, enquanto o Rio de Janeiro 24\%, Paraná e São Paulo possuem as menores alíquotas com 18\% e 12\% respectivamente.

Ilustração 1 - Alíquotas de ICMS dos Estados Brasileiros.

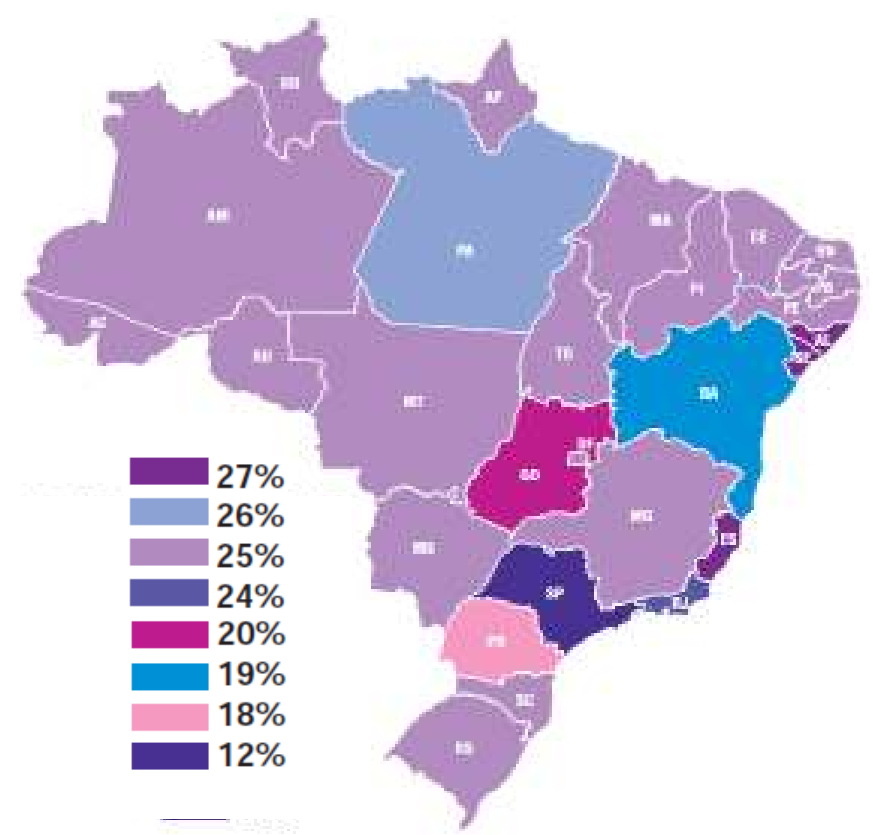

Fonte: Fecombustíveis (2011).

A redução da alíquota do ICMS resultou em alta ou baixa penetração do etanol frente à gasolina, pois a redução do imposto, geralmente, resultou em menor preço para o consumidor final, mas isso depende se houve repasse desse desconto no decorrer da cadeia até o consumidor final, o que geralmente ocorreu.

O Apêndice 1 está relacionado o volume de vendas por estado da gasolina $\mathrm{C}$ e do etanol hidratado, pelos distribuidores de combustíveis, no período de 2000 a 2009. Na coluna 
"PEN.ET" foi calculado a penetração do etanol em cada um dos Estados brasileiros. Para se chegar aos resultados expostos dividiu-se o volume de vendas do etanol pela soma dos volumes de vendas da gasolina e do etanol. Neste sentido, observa-se que no ano de 2000, a média Brasil da penetração etanol frente á gasolina era de apenas $17 \%$ e nos dois anos subseqüentes se observa uma queda de 3\% percentuais a cada ano. Mas, depois do lançamento do carro flex fuel é possível se observar uma rápida penetração do etanol hidratado no Brasil, atingindo em 2009, 39\% de no rol dos combustíveis do ciclo Otto ${ }^{2}$.

Observando os Estados brasileiros e contrapondo com as alíquotas adotadas por eles, analisando especificamente o Estado de São Paulo que passou adotar alíquota de 12\% desde o ano de 2003, observa-se que no ano seguinte em 2004 que o Estado supera em dez pontos percentuais a média Brasil; assim como também conquista o maior percentual de penetração do produto da região Sudeste. Nos anos subseqüentes, a penetração do produto cresce até superar o volume de vendas das gasolinas, em 2008. O Estado encerra o ano de 2009 com a maior penetração do etanol do país com 56\%.

Analisando os Estados do Paraná e da Bahia, que apresentam a segunda e a terceira menor alíquota do ICMS, com $18 \%$ e 19\%, respectivamente, esses dois estados apresentam também forte penetração do etanol; em 2009 o Estado do Paraná atinge praticamente $43 \%$ de penetração do etanol, sendo quase quatorze pontos percentuais em relação a média da região Sul. O mesmo acontece com o estado da Bahia, que em atinge $34 \%$ de penetração do etanol hidratado, também bem acima da média de $28 \%$ da região Nordeste.

Obviamente que não se pode atribuir a penetração do etanol exclusivamente a alíquota do ICMS, outros fatores necessitam ser analisados no contexto, como a proximidade da área produtora, número da frota de veículo de motores exclusivo a etanol e motores flex fuel assim como também quantidade de dias no ano em que o etanol apresentou paridade $^{3}$ de preços frente à gasolina. Contudo, observa-se claramente que no ano em

\footnotetext{
${ }^{2}$ Ciclo Otto é a tecnologia dos motores de ignição movidos por centelha (ou seja, exclui-se carros movidos a diesel).

${ }^{3}$ Paridade do etanol hidratado a gasolina significa dizer que o produto estava mais competitivo que o segundo mesmo considerando que o poder calorífico do etanol hidratado é $30 \%$ menor que a gasolina $\mathrm{C}$.
} 
que os Estados promoveram a redução da alíquota conseqüentemente houve um aumento na penetração do etanol frente à gasolina.

A redução do IPI durante o período dezembro de 2008 a março de 2010 representou na explosão de vendas dos carros de motores flex fuel como pode ser observado no Anexo I, no ano de lançamento (2003) os carros providos com essa tecnologia estes representaram apenas $4 \%$ de todos os veículos leves e de passeio vendidos; saltando para 23\% em 2004 e ultrapassando 90\% de participação em 2008 e 2009 com 2.3 e 2.6 milhões de veículos flex fuel vendidos respectivamente.

De acordo com a ANFAVEA (2010), essa decisão governamental promoveu a renovação mais acelerada da frota do país, favoreceu o etanol e permitiu ao consumidor poder de decisão para abastecer o combustível que lhe é mais conveniente. Contudo, alguns especialistas atribuem a esse último fator, o grande motivador para o sucesso das vendas dos veículos de motores flex fuel, visto que, o consumidor percebeu que a tecnologia poderia proporcionar oportunidade de economizar em despesas com combustível. Já em 2007, mesmo antes da redução do imposto, os carros de motores flex fuel, ultrapassaram as vendas dos carros movidos exclusivamente à gasolina (Anexo I).

Percebe-se, também, que o país atingiu em 2009 a frota recorde superando a marca de 2.8 milhões de veículos leves e de passeio; o que resultou invariavelmente em maior demanda por combustível. E, objetivando assegurar o abastecimento, ao longo dos anos, o governo lançou medidas preventivas, aumentando ou diminuindo o percentual de adição do etanol anidro na gasolina. O Gráfico 1 demonstra o volume de vendas da gasolina e o consumo do etanol anidro no período de 2000 a 2009. Logo abaixo, está a Tabela 2 correlacionando o ano e o percentual do etanol anidro a ser adicionado à gasolina de acordo com a regulamentação em vigor. 
Gráfico 1 - Evolução das vendas de gasolina C (m3) e Etanol Anidro (m3), pelos distribuidores de combustíveis no período de 2000 a 2009 - Brasil.

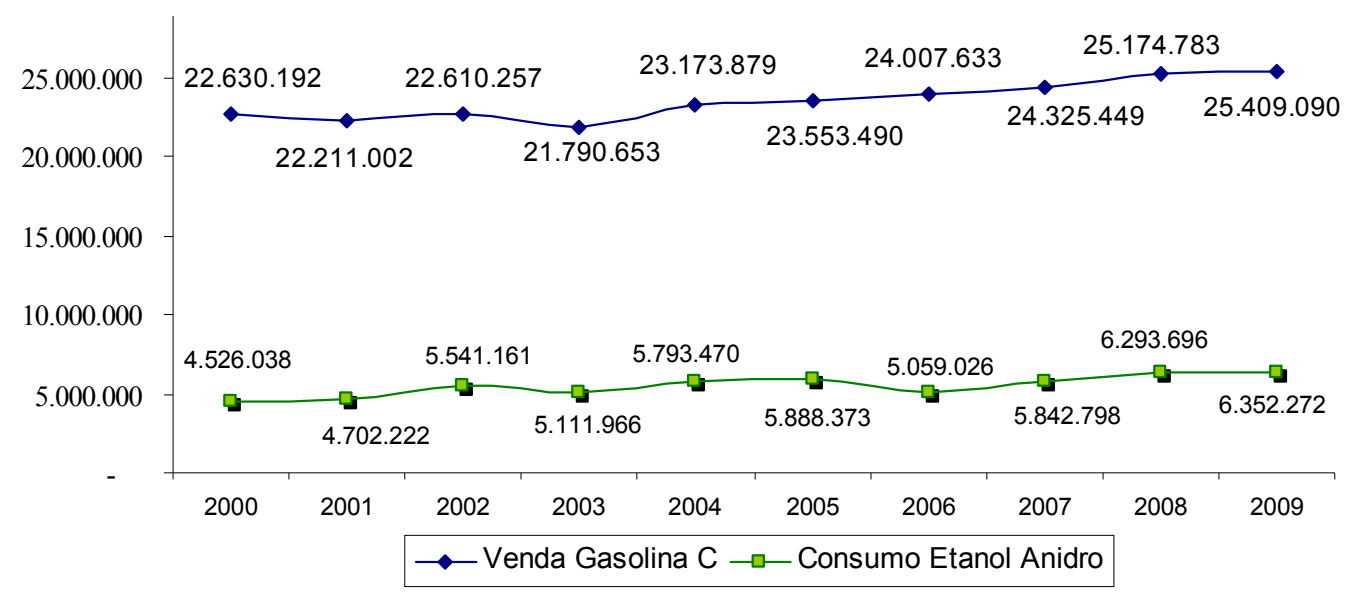

Fonte: ANP.

É importante salientar que o cálculo do volume de vendas do etanol anidro, tomou-se como base a legislação em vigor, conforme demonstra tabela 2, porém não foram considerados os dias exatos que passou a vigorar a mudança no percentual de mistura. Por exemplo, no ano de 2001, durante os meses de janeiro a maio até o dia 30, o percentual regulamentado foi de $20 \%$, passando a vigorar a partir de 31 de maio o percentual de $24 \%$. No cálculo realizado pela autora, incluiu o dia 31 como ainda se fosse $20 \%$. O mesmo acontece nos períodos subjacentes e, por esse motivo, ocorreram pequenas diferenças do volume total de etanol anidro consumido no país por períodos.

Tabela 2 - Percentual de adição de etanol anidro à gasolina por períodos conforme legislação em vigor.

\begin{tabular}{|ccl|}
\hline Período & Percentual & \multicolumn{1}{c|}{ Legislação } \\
\hline $01 / 01 / 01-30 / 05 / 01$ & $20 \%$ & Decreto 3.552, de 04/08/2000 \\
$31 / 05 / 01-09 / 01 / 02$ & $22 \%$ & Decreto 3.824, de 29/05/2001 \\
$10 / 01 / 02-30 / 06 / 02$ & $24 \%$ & Portaria 589, de 10/12/2001 \\
$01 / 07 / 02-31 / 01 / 03$ & $25 \%$ & Portaria 266, de 21/06/2002 \\
$01 / 02 / 03-31 / 05 / 03$ & $20 \%$ & Portaria 17, de 22/01/2003 \\
$01 / 06 / 03-28 / 02 / 06$ & $25 \%$ & Portaria 554, de 27/05/2003 \\
$01 / 03 / 06-19 / 11 / 06$ & $20 \%$ & Portaria 51, de 22/02/2006 \\
$20 / 11 / 06-30 / 06 / 07$ & $23 \%$ & Portaria 278, de 10/11/2006 \\
$01 / 07 / 07-31 / 01 / 10$ & $25 \%$ & Portaria 143, de 27/06/2007
\end{tabular}

Fonte: Fecombustíveis (2011) 
Analisando especificamente o período de 01/07/02 a 19/11/06 observa-se, claramente, a atuação do governo aumentando o percentual do etanol anidro à gasolina quando este não ultrapassa $10 \%$ de participação na formação do preço final da gasolina. Por outro lado, a redução do percentual do etanol anidro à gasolina surge dois fatores que contribuíram para a remuneração por produto (açúcar, etanol hidratado, etanol anidro) ao produtor no mercado interno e o preço do mercado internacional do açúcar.

De acordo com o Centro de Estudos Avançados em Economia Aplicada ${ }^{4}$ - CEPEA, os meses de setembro à dezembro de 2002 observa-se que a contribuição do etanol anidro na formação de preços da gasolina salta de $8.95 \%$ para $10.58 \%$. Em janeiro de 2003 este índice salta para $11.43 \%$ o que motiva o governo a reduzir o percentual de mistura do etanol anidro na gasolina de $25 \%$ para $20 \%$. E a razão pode ser atribuída ao preço do açúcar estar mais favorável ao produtor do que a produção dos etanóis. Ainda de acordo com o instituto, no mês de dezembro de 2002 o açúcar no mercado interno remunerou $51 \%$ a mais o produtor em relação ao etanol anidro e $65 \%$ mais em relação ao etanol hidratado. Até março de 2003 era mais favorável ao produtor produzir açúcar do que etanóis. Em janeiro/03 a relação de remuneração do açúcar para o produtor em relação ao etanol anidro e hidratado respectivamente era de era de 35\% e 50\%. Ou seja, neste período, era mais favorável produzir açúcar do que etanóis. Somente em abril do mesmo é que a relação cai para $1 \%$ e $16 \%$, motivando o governo a aumentar a adição do etanol anidro na gasolina novamente para o patamar de $25 \%$ em junho de 2003 .

O mesmo comportamento se repete de forma parecida nos anos seguintes. Quando a participação do etanol anidro na formação do preço final da gasolina ultrapassa os dois dígitos o governo opta por reduzir o percentual de adição do produto. Como também a alta de preços do etanol anidro está fortemente associada ao preço do mercado interno comparado com o preço do produto no mercado externo. Vale lembrar que sendo um produto oriundo da agricultura, as condições climáticas podem favorecer ou prejudicar a oferta do produto o que conseqüentemente influencia o preço final dos etanóis.

\footnotetext{
${ }^{4}$ Dados disponíveis no site do órgão. $<$ http://www.cepea.esalq.usp.br/imprensa/?page=846> acessado em 31. dez. 2010.
} 
É possível concluir que o governo ainda está fortemente presente no setor; é possível afirmar ainda que a atuação do Estado atualmente está muito mais relacionada como um orquestrador do que um controlador vivido na década passada. Tornando os preços livres possibilitou um ambiente mais competitivo, promovendo assim melhorias em toda a cadeia da cana-de-açúcar. Aos distribuidores de combustíveis couberam se adaptar as novas legislações e demandas emergentes do mercado. E durante o período de transição do paternalismo estatal para o mercado livre observou-se ainda a saída de importantes competidores e em seguida a concentração de mercado. Obviamente, existem fatores a serem analisados nesse contexto mas sem dúvida alguma a atuação do papel do governo durante esses anos foi fundamental para a realidade atual.

\subsubsection{Macroambiente solo}

Almeida (2010) define o macroambiente solo, como o estudo das tendências populacionais e suas características. As variáveis pertinentes a esta dimensão podem ser a faixa de renda da população, escolaridade, idade, região entre outras. Kotler e Armstrong (2007) enfatizam que as tendências demográficas são extremante importante para os profissionais de marketing, pois têm implicações diretas nos negócios. Os autores destacam como as mudanças na estrutura etária da população e as demandas inerentes a cada grupo / subgrupos da sociedade, o aumento da diversidade étnica e

racial, o nível educacional e as alterações geográficas (migração das pessoas dentro do país) alteraram a demanda.

Dibb (1996) acrescenta ainda que o estudo demográfico tornou-se extremamente relevante devido ao grau crescente de urbanização das cidades. De acordo com o autor, esse processo promove melhores salários, novas oportunidades de trabalho, mas que também implicam no aumento significativo por maior demanda em infra-estrutura, moradia, transporte, alimentação e vestuário. Outra tendência observada, em função do processo de urbanização das cidades são as mudanças na estrutura familiar em que cada 
vez mais mulheres ingressam no mercado de trabalho, adiam casamentos e tem cada vez menos filhos, resultando em oferta de novos produtos serviços as empresas..

Neste sentido, Frank e Enkawa (2009) ressaltam também a importância de se estudar como o crescimento econômico e desenvolvimento das cidades alteram também de maneira significativa a percepção do consumidor em relação a satisfação geral dos produtos e serviços. Em muitos casos, as empresas são obrigadas a rever o portfólio de produtos e serviços a fim de atender e se adequar as novas exigências do mercado. Para Kotler e Caslione (2009) os clientes estão cada vez mais sofisticados, exigentes, menos fiéis e estão mais abertos para experimentar e comparar marcas genéricas; buscam redução de preços e estão mais sensíveis a similaridade na oferta de produtos entre as empresas concorrentes. Além disso, os consumidores passar a ter alta expectativa em relação aos serviços. Acrescenta-se também que a vida moderna implica em menor tempo para realizar todas as atividades que as pessoas desejariam realizar e por esse motivo as pessoas não dispõem de tempo e urgem por maior comodidade.

Neste contexto, Oliver (1999) propõe o debate de que o maior desafio das organizações é atuar tão dinamicamente, ágil e flexível como é o mercado atual. Destacando também que este novo consumidor é acima de tudo muito mais bem informado, politizado e globalizado.

Reis (2003) observa que se no passado um posto se resumia apenas a bomba e o frentista, hoje, é observado evolução dos postos para um conglomerado de serviços. E, assim o autor afirma de maneira categórica que em muito breve os postos de combustíveis terão que se reinventar para atender às demandas do consumidor. Um ponto importante é que grande parte dos distribuidores de combustíveis está presente no país há várias décadas, e assim, puderam acompanhar as profundas transformações da sociedade brasileira como também perceber a necessidade de adequar os seus negócios para atender as expectativas emergentes de um país em acelerado processo de desenvolvimento.

Para ilustrar o desenvolvimento do país, seguirão algumas análises incluindo décadas anteriores a fim de se conhecer melhor a evolução das características da população brasileira no que tange evolução do grau de urbanização das cidades, educação, 
evolução da população total residente, faixa etária, sexo e renda e as possíveis interrelações entre elas e as conseqüências para os distribuidores de combustíveis.

E assim, na década de 1940, o Brasil era considerado um país primariamente rural e de majoritariamente de analfabetos. Somente na década de 1980 é que o número total de habitantes vivendo nas cidades supera o número de pessoas vivendo no campo. A realidade atual, de acordo com o IBGE - Instituto Brasileiro de Geografia e Estatística ${ }^{5}$, através do último censo realizado, em 2010, o Brasil passou a ter $84 \%$ da população vivendo nas cidades.

A educação continua sendo um grande desafio, pois ainda, em 2010, 7,4\% da população com 15 anos ou mais são consideradas analfabetas. Mas, a situação é ainda mais grave, quando se analisa a taxa de analfabetismo funcional das pessoas com 15 anos ou mais, este índice chega a 20\%, de acordo o próprio IBGE. Por outro lado, é importante notar avanços no nível de escolaridade da população, no início da década de 1990 havia 19,17\% da população com menos de 1 ano de estudo; 17,94\% com 1 a 3 anos; $33,09 \%$ com 4 a 7 anos e 29\% com mais de 8 anos de estudos. Em 2006, último ano da pesquisa realizada pelo instituto, observa-se uma queda considerável no percentual de pessoas com menos de 1 ano de estudo passando a configurar 11,18\% e positivamente um forte crescimento no percentual de pessoas com mais de 8 anos de estudos representando $50,9 \%$.

A década de 1940 eram apenas 41 milhões de brasileiros; na década de 1980 a população ultrapassa os 100 milhões atingindo 119 milhões de brasileiros. Comparando o censo demográfico de 1940 com o de 2010, o Brasil cresceu $463 \%$ atingindo mais de 190 milhões. Contudo, vale salientar que as regiões Sul e especialmente a região Sudeste são concentradoras de maior densidade demográfica do país; essas regiões isoladas são responsáveis por abrigar quase 60\% da população (Censo/2010). A Ilustração 3, relaciona a população residente do país classificando-a entre urbana e rural de acordo com as regiões do país. A maior concentração de pessoas vivendo em zonas rurais está nas cidades da região Nordeste a menor concentração está na região CentroOeste.

\footnotetext{
${ }^{5}$ Dados disponíveis no site do órgão: <http: $\backslash \backslash$ www.ibge.gov.br> acessado em 24 jun. 2011.
} 
Ilustração 2 - População Urbana e Rural por Região

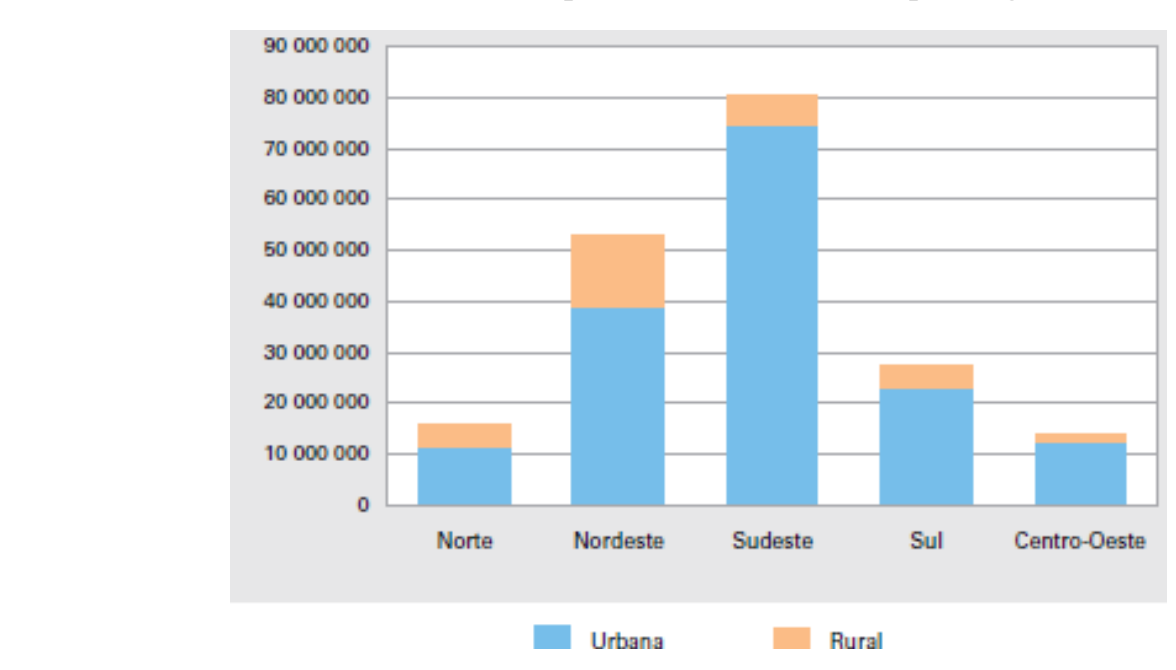

Fonte: IBGE.

Essas diferenças regionais também precisam ser observadas, pois as demandas e as necessidades dos consumidores podem diferir bastante de região para região. Um produto ou serviço pode parecer saturado em uma região enquanto poderá ser ainda uma necessidade em outro. Neste sentido, Kotler (2000) afirma que muitas vezes as empresas necessitam adaptar seus produtos e serviços para atender as preferências ou exigências dos consumidores locais. O nível de adaptação, segundo o autor pode variar muito como sabores, embalagens, cores, textura, etc. O objetivo único é atender melhor as expectativas locais.

O que é de chamar muita atenção entre o censo de 1991 comparado com o de 2010 é a taxa de crescimento absoluto da população residente no país. É possível observar que essa a taxa de crescimento da população residente não segue a tendência dos censos realizados em décadas anteriores. Enquanto as regiões Norte, Nordeste e Centro-Oeste apresentam crescimento ao contrário, as regiões Sul e Sudeste apresentam declínio do número total de residentes. A região Norte teve um aumento de quase 95 mil de residentes, a região Nordeste aumentou de 5.244 para 5.344 milhões de residentes; a região Centro-Oeste aumentou de 2.209 para 2.421 milhões de residentes; por outro lado as regiões Sul e Sudeste apresentaram uma queda no número absoluto de residentes. O Sul caiu de 2.978 para 2.279 milhões de residentes e o sudeste apresentou a maior queda de todas as regiões caindo de 9.972 para 7.951 milhões de residentes. 
Esse é um ponto também muito importante a ser acompanhado pelos distribuidores de combustíveis e pode se configurar uma oportunidade para ingressar em novos mercados assim como também uma ameaça aos investimentos realizados nas áreas que tradicionalmente receberam maior investimento por concentrar maior parte da população.

Esse mesmo efeito se observa quando se analisa a frota do país por região no período de 2000 a 2009. Através da Tabela 3 se observa que enquanto as regiões Sul e Sudeste já apresentam leve queda em relação ao ano de 2000 comparado com 2009 as demais regiões do país vem aumentando sua participação no total de automóveis circulante. A região Sul se manteve estável ao longo do período com um pouco mais de $20 \%$, mas a região Sudeste representava, em 2000, 60\% de participação do total de veículos circulantes no país e em 2009 cai para 57\%. Justamente o contrário acontece na região Norte, Nordeste e Centro-Oeste que aumentam em 1 ponto percentual a participação de veículos sobre o total de veículos se comparado o ano de 2005 com 2009. É importante lembrar que apesar da queda ou crescimento percentual ter sido pequena no período verificado é importante entender esse processo de migração, por trás destes números podem esconder tendências das quais terão certamente implicações para os distribuidores de combustíveis.

Tabela 3 - Tabela de comparação do número total de automóveis leves por região.

\begin{tabular}{|l|c|c|c|}
\hline Regiões & $\mathbf{2 0 0 9}$ & $\mathbf{2 0 0 5}$ & $\mathbf{2 0 0 0}$ \\
\hline Norte & $3 \%$ & $2 \%$ & $2 \%$ \\
\hline Nordeste & $11 \%$ & $10 \%$ & $10 \%$ \\
\hline Sudeste & $57 \%$ & $58 \%$ & $60 \%$ \\
\hline Sul & $22 \%$ & $22 \%$ & $21 \%$ \\
\hline Centro-Oeste & $8 \%$ & $7 \%$ & $7 \%$ \\
\hline
\end{tabular}

Fonte: Denatran ${ }^{6}$.

Vale salientar, porém que todas as regiões do país apresentaram forte crescimento no número total de veículos circulantes; Conforme a Tabela 4, em 2000, o Brasil tinha quase 30 milhões de veículos, em 2005 ultrapassa os 42 milhões e em 2009 apresenta

\footnotetext{
${ }^{6}$ Disponível em <http://www.denatran.gov.br/> acessado em 24 jun. 2011.
} 
um crescimento de $29 \%$ em relação a 2005 com uma frota total de quase 60 milhões de veículos. A região Sul e Sudeste juntas é responsável por quase $80 \%$ da frota total circulante do país ao longo do período. Em terceiro lugar, segue a região Nordeste com um pouco mais de 8 milhões de veículos, em quarto lugar segue a região Centro-Oeste com mais de 5 milhões de veículos e por fim a região Norte com mais de 2 milhões de veículos.

Tabela 4 - Tabela de comparação de número total de frota de veículos e automóveis leves (Auto Leves) circulantes no país e de automóvel entre os anos 2009, 2005 e 2000

\begin{tabular}{|l|r|r|c|c|r|r|}
\hline \multirow{3}{*}{ Brasil } & \multicolumn{2}{|c|}{$\mathbf{2 0 0 9}$} & \multicolumn{2}{c|}{$\mathbf{2 0 0 5}$} & \multicolumn{2}{c|}{$\mathbf{2 0 0 0}$} \\
\cline { 2 - 7 } & Frota Total & \multicolumn{1}{|c|}{ Auto Leves } & Frota Total & \multicolumn{1}{c|}{ Auto Leves } & \multicolumn{1}{c|}{ Frota Total } & \multicolumn{1}{c|}{ Auto Leves } \\
\cline { 2 - 7 } & 59.361 .642 & 34.536 .667 & 42.071 .961 & 26.309 .256 & 29.722 .950 & 19.972 .690 \\
\hline Norte & 2.506 .253 & 914.085 & 1.504 .910 & 599.285 & 836.936 & 393.993 \\
\hline Nordeste & 8.294 .569 & 3.716 .592 & 5.261 .617 & 2.666 .048 & 3.381 .899 & 1.955 .091 \\
\hline Sudeste & 30.843 .618 & 19.727 .640 & 22.545 .857 & 15.317 .238 & 16.777 .058 & 11.938 .823 \\
\hline Sul & 12.435 .607 & 7.479 .547 & 9.199 .352 & 5.785 .609 & 6.396 .129 & 4.281 .670 \\
\hline $\begin{array}{l}\text { Centro- } \\
\text { Oeste }\end{array}$ & 5.281 .595 & 2.698 .803 & 3.560 .225 & 1.941 .076 & 2.330 .928 & 1.403 .113 \\
\hline
\end{tabular}

Fonte: Denatran

Outro ponto muito importante a ser analisado sobre as características da população brasileira está demonstrado na Ilustração 3. É possível observar que existem diferenças regionais nas características da população residentes de acordo com o sexo e idade.

Observa-se que a região Norte do país se configura a população mais nova do país, em seguida está a região Nordeste com a segunda maior população mais jovem. De acordo com o IBGE, essas regiões apresentavam taxa de fecundidade até a década de 1980, muito mais elevadas do que o restante do país, o que explica a concentração de pessoas mais novas nessas regiões. Contudo, observa-se que na região Norte, o percentual de crianças menores de 5 anos caiu de $12,7 \%$ para 9,8\% entre 2000 e 2010; enquanto a população de idosos cresceu de 3,6\% para 4,6\% no mesmo período. O mesmo se observa na região Nordeste, a população de crianças menores de 5 anos caiu de $10,6 \%$ para $8 \%$ e o de idosos cresceu de 5,8\% para 7,2\% também no mesmo período respectivamente. Já as regiões Sul e Sudeste, ainda conforme Ilustração 3 demonstra maior concentração de pessoas mais velhas do país. De acordo com o IBGE, essas regiões já apresentavam queda na taxa de fecundidade desde a década de 1960. E em 
2010, a população idosa das duas regiões já se mostra superior a população de crianças menores de 5 anos levemente acima de $6 \%$ contra $8,1 \%$ da população de idosos. A região Centro-Oeste apresenta características muito parecidas com a média do país, mas a década de 1970 marcou forte queda na taxa de fecundidade da região, afirma o IBGE. Em relação a população de crianças menores de 5 anos observou-se uma queda de 9,8\% em 2000 para 7,6\% em 2010. O contrário acontece na população de idosos apresentando um crescimento de 4,3\% em 2000 para 5,8\% em 2010.

Dibb (1996) afirma que já é uma realidade mundial constata a queda na taxa de natalidade dos países e se estima que até o final deste século, $1 / 3$ da população mundial esteja concentrada na faixa etária dos 30-50 anos de idade. Uma faixa etária considerada "high spending category", ou seja, categoria de gastos elevados. O impacto dessa tendência será o aumento da demanda por variados produtos e serviços que atendam as necessidades de uma sociedade que envelhece rapidamente, como serviços financeiros, tipo de habitação, carros, serviços domésticos entre outro. Em contrapartida, é esperado uma queda na demanda por artigos infantis tornando-se acentuada ao longo dos anos. 

de idade - Brasil e Grandes Regiões

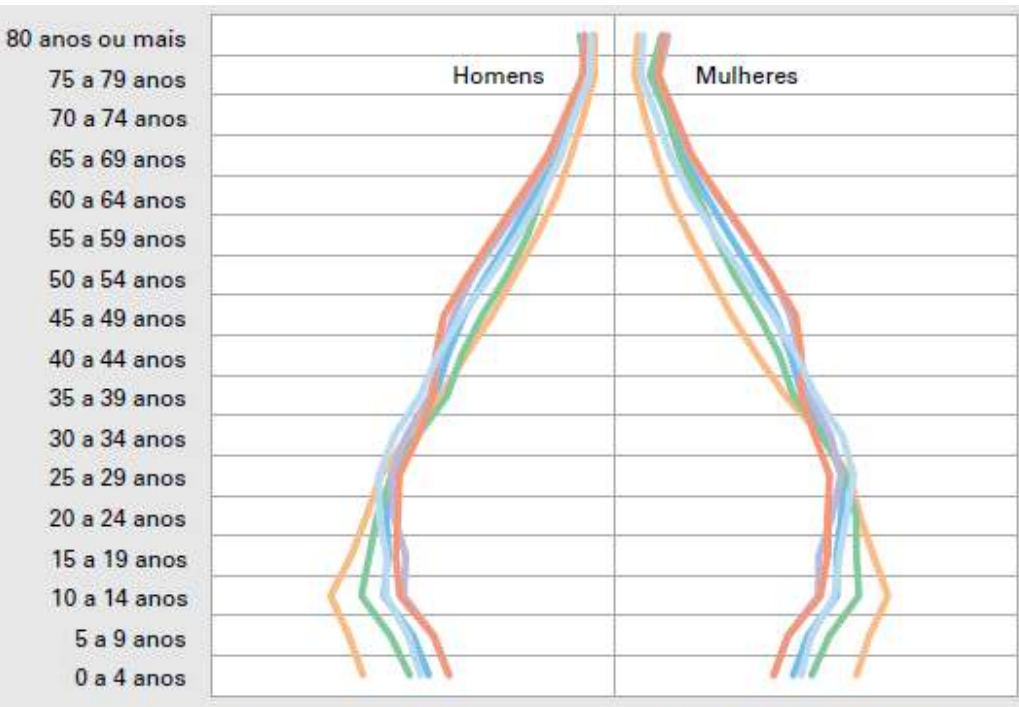

Fonte:

$\begin{array}{lllllllllllllllll}8,0 & 7,0 & 6,0 & 5,0 & 4,0 & 3,0 & 2,0 & 1,0 & 0,0 & 1,0 & 2,0 & 3,0 & 4,0 & 5,0 & 6,0 & 7,0 & 8,0\end{array}$

IBGE

(2010)

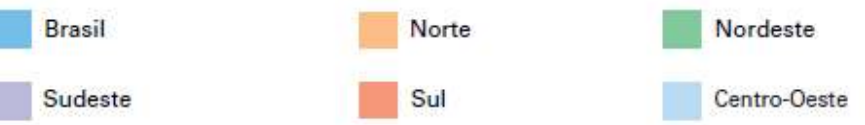

No que tange a composição populacional por sexo, em 2010, a região Norte é a única do país a apresentar um maior número de homens em relação as mulheres (102 homens para cada 100 mulheres). A relação média do país, para o mesmo ano, é de 96 homens para cada 100 mulheres; o que permaneceu praticamente estável se comparado com o Censo de 2000 que era de 96,6. As regiões Nordeste e Sul apresentam relação igualmente de 96,3\% enquanto as Regiões Centro-Oeste e Sudeste apresentam respectivamente $98,4 \%$ e $94,6 \%$. O IBGE chama atenção que esse índice não é homogêneo entre as cidades e menciona que o Rio de Janeiro, por exemplo, apresenta uma relação bem inferior a média da região com 91,2 homens para cada 100 mulheres. O mesmo se observa em outras cidades e é preciso tomar cuidado com as generalizações neste sentido.

Em relação ao sexo, o que mais chama atenção quanto ao índice crescente de mulheres economicamente ativas e ocupadas como sendo a principal responsável do domicílio, ou seja, como chefes de família. Em dezembro de 2009 o país passou a ter $32 \%$ das mulheres comandando os lares, no início da década, esse índice era próximo de $25 \%$. Além disso, observa-se que as mulheres tem mais anos de estudos do que os homens em todas as regiões do país. 
O Sindicom (2010) destaca que o fato de ter mais mulheres no mercado de trabalho ampliou oportunidades de negócios e de crescimento das lojas de conveniências no país, é o reflexo disso. Porém, salientam que as mulheres são, realmente, mais exigentes do que os homens quando se refere ao atendimento elas valorizam outros atributos de maneira diferenciada para atender às necessidades do público; elas também necessitam de serviços que promovam maior comodidade para enfrentarem com responsabilidade a dupla jornada de trabalho: fora e dentro de casa.

A Fecombustíveis (2011) relata que os grandes distribuidores de combustíveis estão atentos a essa mudança e passaram a investir e em oferecer um mix de produtos mais variados dentro das lojas de conveniências, proporcionando um ambiente agradável e seguro, preparando os frentistas no sentido de saberem lidar com os clientes, mantendo um relacionamento de cortesia e de educação ao servir.

A Fecombustiveis também destaca que as lojas de conveniência passaram a oferecer à clientela opções de serviços gratuitos como acesso á internet, produtos semi-prontos, linha de produtos saudáveis, embalagens com menores proporções e que não são encontrados nas redes de supermercados. Tudo isso, pensando em melhor servir à comunidade

Outro aspecto importante se refere a rentabilidade nos negócios, visto que: quanto maior é a renda, maior é o poder de consumo de uma população. Frank e Enkawa (2009) constataram que o aumento de renda permite que as pessoas ampliem o número de itens consumidos proporcionando melhorias significativas no bem-estar. Mas, o IPEA (2010) afirma que no que se refere a renda da população, o país é imensamente desigual e apresenta índice de Gini $^{7}$ aquém dos outros países da America Latina. Salienta que houve uma redução nas desigualdades de renda da população, de acordo com o IBGE, em 2001, o índice de Gini era de 0,57 demonstrando uma forte concentração da renda ou da propriedade de terra. Mas, ao longo dos anos, o país foi reduzindo este índice e alcançou em 2008 0,52. O que significa dizer que mesmo com

\footnotetext{
7 “O índice de Gini é usado para medir a concentração de renda e da terra. Varia de 0 a 1. Quanto mais próximo de 1, mais concentrada é a renda ou a propriedade da terra”. (IPEA, 2010 p. 75).
} 
os avanços vivenciados ainda há forte discrepância de renda entre as classes sociais e entre as regiões do país.

É fácil concluir que as mudanças da sociedade brasileira permitiram que os distribuidores ampliassem atuação para novos mercados, expandisse áreas de atuação, agregassem novos negócios e serviços dentro do espaço do posto de combustíveis. E o cenário econômico do país para os próximos anos são positivos em relação ao crescimento e desenvolvimento das classes sociais o que certamente irá representar novos desafios e novas oportunidades para as organizações.

Por outro lado, nota-se que as diferenças regionais e/ou culturais do país ainda representam um grande desafio para os distribuidores de combustíveis. Como descreve Oliver (1999) a tendência na prestação dos serviços em um futuro próximo é uma oferta cada vez mais personalizada para um consumidor cada vez exigente, bem informado e que deseja uma variedade no momento de escolha.

O carro flex fuel, nesse contexto, permitiu ao consumidor novas oportunidades de abastecimento - somente etanol, somente gasolina, ou a mistura em qualquer proporção dos dois combustíveis. Os distribuidores que, antes tinham uma realidade estática e de apenas um ou dois produtos passaram a gerenciar um portfólio maior, assim como necessitaram entender o comportamento deste novo consumidor que surge no mercado. Por isso, abastecer o veículo com etanol implica em mais visitas ao posto de combustíveis para abastecimento o que vem favorecendo aos distribuidores oportunidade de ampliar as vendas de outros produtos, além dos correlacionados com combustíveis.

Assim o macroambiente; solo se torna extremamente relevante não apenas para desenvolver as melhores ferramentas de marketing, mas como também direcionar esforços em investimentos organizacionais futuros. 


\subsubsection{Ambiente operacional}

Conforme Almeida (2010) a análise do ambiente operacional visa compreender como as organizações irão funcionar em suas operações diante as tecnologias futuras. Além disso, pretende conhecer como se dará o relacionamento futuro com fornecedores, clientes e concorrentes. Certo et al (2005) define "fornecedores" como aqueles que entregam os recursos necessários para que a organização estes possam transformar-los em produtos e serviços a serem comercializados. Os "clientes" como aqueles que compram os produtos e serviços fornecidos pela organização; e por fim "concorrentes" como aqueles em que a organização terá que disputar para conseguir recursos e clientes. Para os distribuidores de combustíveis deve-se compreender como "fornecedores" as usinas de etanol e as refinarias de gasolina; como "clientes", os revendedores de combustíveis; e os "concorrentes", todos os demais distribuidores.

O fator tecnológico passa a ter grande destaque, neste ambiente, uma vez que são geralmente responsáveis por mudanças drásticas que influenciam todos os setores organizacionais assim como também na vida das pessoas. Kotler e Armstrog (2007) enfatizam que as tecnologias mudam rapidamente como também geram novos mercados e oportunidades. Aaker (2007) por outro lado, afirma que as tecnologias podem propiciar e criar um benefício imediato e tangível para o consumidor.

O desenvolvimento do carro de motores flex fuel é um exemplo disso, essa tecnologia gerou benefícios imediatos para o consumidor (motorista) visto a ampliação das opções para o abastecimento e possibilidade de redução dos gastos financeiros com combustível. E para os distribuidores de combustíveis gerou uma série de implicações que podem ser listadas desde o aprendizado ao gerenciar um produto de origem agrícola até o acirramento da competição entre novos distribuidores e um novo perfil de consumidor que se demonstra mais sensível a preço e menos fiel a marca ${ }^{8}$.

Para melhor compreender os efeitos dessa tecnologia no ambiente operacional dos distribuidores de combustíveis será demonstrada a evolução dos distribuidores de

\footnotetext{
${ }^{8}$ Afirmação relatada por todos os gerentes dos distribuidores de combustíveis durante as entrevistas.
} 
combustíveis, a composição da frota de veículos leves destacando a penetração do carro de motores flex fuel em detrimento dos carros movidos exclusivamente a gasolina e por fim a evolução da produção dos etanóis no país (Gráfico 3). É preciso destacar que praticamente todo o volume produzido no período se iguala consumido no país.

Outro ponto muito importante no que tange ao cenário tecnológico e que precisa ser monitorado pelos distribuidores deve-se ao conjunto de novas opções de motores de

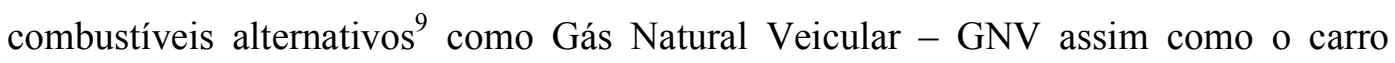
elétrico que já é uma realidade em vários países; outro aspecto a se consideraré o gerenciamento contínuo para o desenvolvimento de motores automotivos mais eficientes e capazes de rodar maior quantidade de quilômetros por litro de combustível.

Analisando inicialmente os fornecedores se observa que com a desregulamentação do setor se ampliou as possibilidades de compra dos distribuidores de combustíveis, uma vez que passaram a não ser mais obrigados a comprar exclusivamente da Petróleo Brasileiro - Petrobras e puderam deliberadamente importar gasolina ou etanol quando assim for conveniente. No que tange ao etanol, a produção ainda é muito pulverizada entre várias usinas de diferentes portes. Mas o que vem sendo observado, ao longo dos últimos anos, é a aquisição de pequenas e médias usinas aos grandes grupos existentes. Shikida et al (2004) e Ramos (2006) destacam que são os grandes grupos que se tornam capazes de investir mais em novas tecnologias melhorando significantemente a eficiência da produção.

Em relação aos clientes se observam uma drástica mudança na estrutura dos postos de serviços. Fernandes (2001) acredita que após o processo de desregulamentação e a transformação do ambiente competitivo obrigou os clientes dos distribuidores de combustíveis a buscar pela redução dos custos, ganhos de escala e aumento da produtividade. Os espaços ociosos passaram a incorporar novos negócios objetivando não somente a redução dos custos em virtude das perdas de margens motivada pelo aumento da competição, mas também agregar mais valor para os consumidores.

\footnotetext{
${ }^{9}$ Deve-se compreender como combustível alternativo o combustível não fóssil.
} 
Um fator lembrado por todos os gerentes dos distribuidores de combustíveis e mencionado por praticamente todos os revendedores foi o aumento considerável dos custos de operação de um posto de combustível. O "Revendedor A"10 mencionou que durante muitos anos um posto pequeno que vendia em torno de 100.000 litros de combustíveis era rentável, mas hoje, é impossível sobreviver em muitas cidades considerando um posto com vendas mensais de 300.000 litros, podendo obter resultados financeiros abaixo das expectativas como também inferiores a anos anteriores.

E, os motivos são simples, observa-se a perda de receita pelo aumento da competição e pelo aumento do custo operacional. O "Revendedor A" ainda faz lembrar, que geralmente, os postos de combustíveis estão localizados nas melhores esquinas da cidade e com a valorização dos imóveis o aluguel se tornou tão elevado que pode inviabilizar a operação de um posto impactando diretamente no resultado financeiro do negócio. Ele menciona também que em alguns casos é mais conveniente, fechar as portas do postos de combustíveis para construir um prédio, por exemplo.Para ele, em breve, serão raros os postos dentro das cidades, afirma que os postos do futuro serão aqueles revendedores capazes de inovar, de oferecer multiplicidade de serviços e de oferecer novas opções e uma experiência diferenciada aos consumidores.

Essa é uma realidade ainda não retratada nos livros e artigos, durante as entrevistas, os gerentes dos distribuidores de combustíveis mencionaram que vem crescendo o número de postos concentrados nas mãos de alguns e poucos revendedores. Este fator poderá implicar sérios riscos para os distribuidores de combustíveis, uma vez que poderá ter sua venda concentrada em um número reduzido de clientes, sendo algo inovador, inusitado na história de distribuição de combustíveis nesse país.

Além disso, depois da introdução do carro flex fuel se observou crescente número de postos bandeiras bancas e uma perda significativa de postos de combustíveis representando marcas dos distribuidores de combustíveis. No Gráfico 2, é possível acompanhar a evolução dos postos bandeira branca durante o período de 2000 a 2009.

\footnotetext{
${ }^{10}$ Entrevista realizada em Campinas no dia 11 jul 2007.
} 
No ano de 2000, eram apenas 2.3 mil postos designados bandeiras brancas, mas em 2009 salta para 16.6 mil postos. Um crescimento de 692\% em nove anos. Nenhum distribuidor de combustíveis conseguiu um crescimento do ponto de vendas tão expressivo quanto esse. Muito pelo contrário, no ano em que os carros de motores flex fuel são lançados no mercado, paralelamente todas as distribuidoras, sem exceção, perdem pontos de vendas (postos de serviços). A BR no ano de 2000, eram 6.890 postos de serviços e passou a ter em 2003 5.296, uma perda de 1.594 postos de serviços; A Ipiranga por sua vez perde 1.518 postos, a Shell 1.574, a Texaco 761, a Esso/Cosan 992. Somadas as perdas de todos os distribuidores perfazem 6.439 postos. É possível observar, também, o crescimento de postos vinculados a outras marcas, ou distribuidores menores como Agip, Repsol ALE etc. que foram somados e agregados em “outros” no gráfico.

Gráfico 2 - Evolução dos postos de serviços de acordo com a bandeira no período de 2000 a 2009

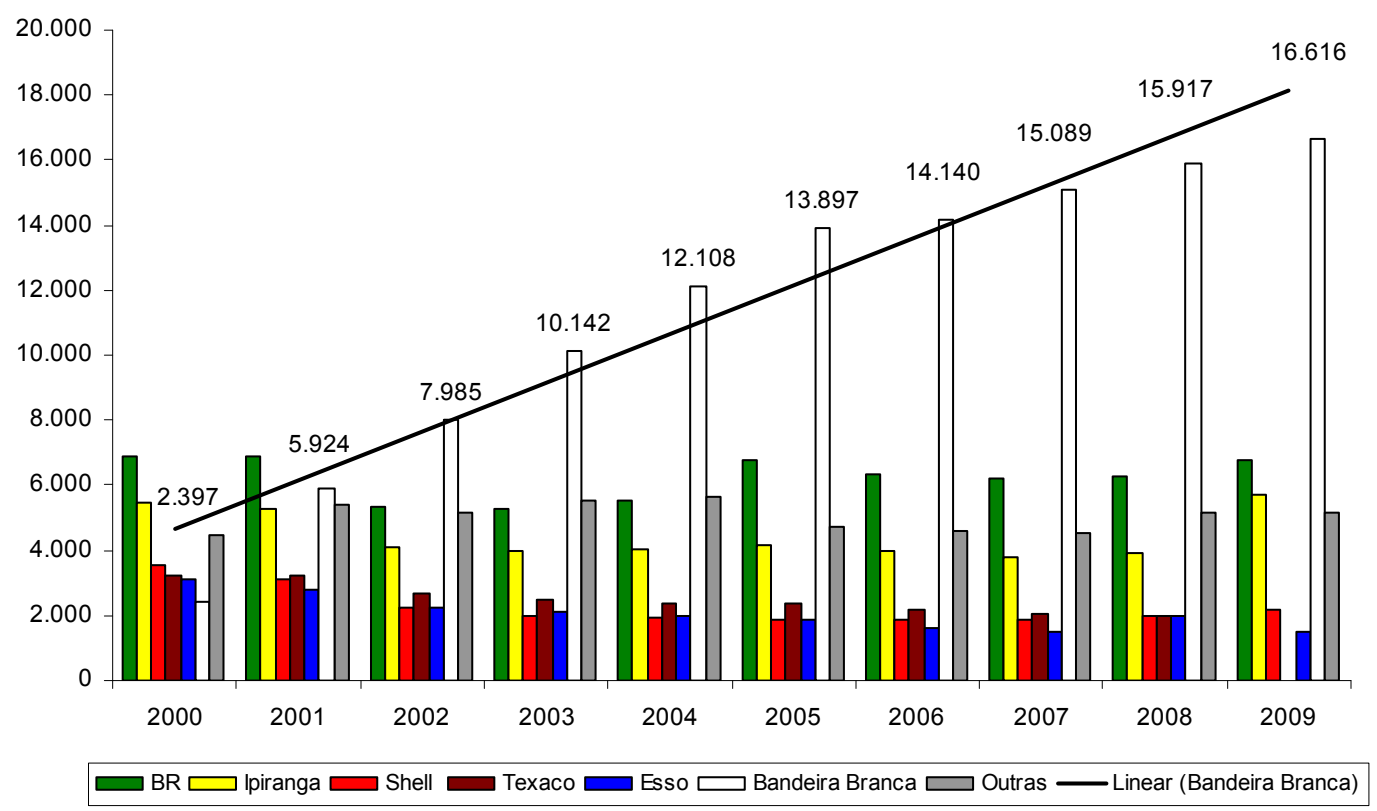

Fonte: ANP (2010)

Considerações: nos anos de 2002 a 2004 o número total de postos da AGIP foi incorporado ao "Outros" (sendo a quantidade somada 1.033, 1.073 e 1.082 respectivamente). E nos anos de 2007 a 2009 O número total de postos da ALESAT foi incorporado a "outros" (sendo a quantidade somada 913, $1.508 \mathrm{e}$ 1.348 respectivamente) 
Em paralelo ao aumento do número total de postos é possível observar também a evolução da produção do etanol anidro e hidratado no país, (Gráfico 3). O aumento da produção do anidro está atrelado ao volume de vendas das gasolinas assim como as decisões governamentais de aumentar ou diminuir o percentual de adição às gasolinas. Já o etanol hidratado é possível verificar um forte aumento na produção em decorrência ao aumento da participação dos carros de motores flex fuel (Anexo I) especialmente em 2006 e 2007 em que os carros flex atingiram 1.430 e 2.0 milhões de veículos, respectivamente. Por sua vez o consumo do etanol hidratado, de acordo com a ANP, no mesmo período respectivamente, atingiu 6.18 e 9.3 milhões de litros. Em 2007, o volume consumido no país praticamente foi o mesmo do produzido. Mas, em 2008, o volume de vendas atingiu 13.29 e em 200916.47 milhões de litros; ao passo que o número de carros flex atingiu 2.3 e 2.6 milhões de veículos, ou seja, mais de $90 \%$ de todos os carros vendidos do ciclo Otto ${ }^{11}$ no país foi flex fuel.

11 É o termo utilizado para classificar os carros que possuem motores que funcionam em quatro tempos: admissão, compressão, explosão e escape. A combustão ocorre por faísca (gerada pela vela de ignição), diferentemente do diesel, que explode só pela compressão da mistura ar-combustível. 
Gráfico 3 - Evolução da produção total Brasil de etanol anidro e hidratado - ano safra ${ }^{12}$

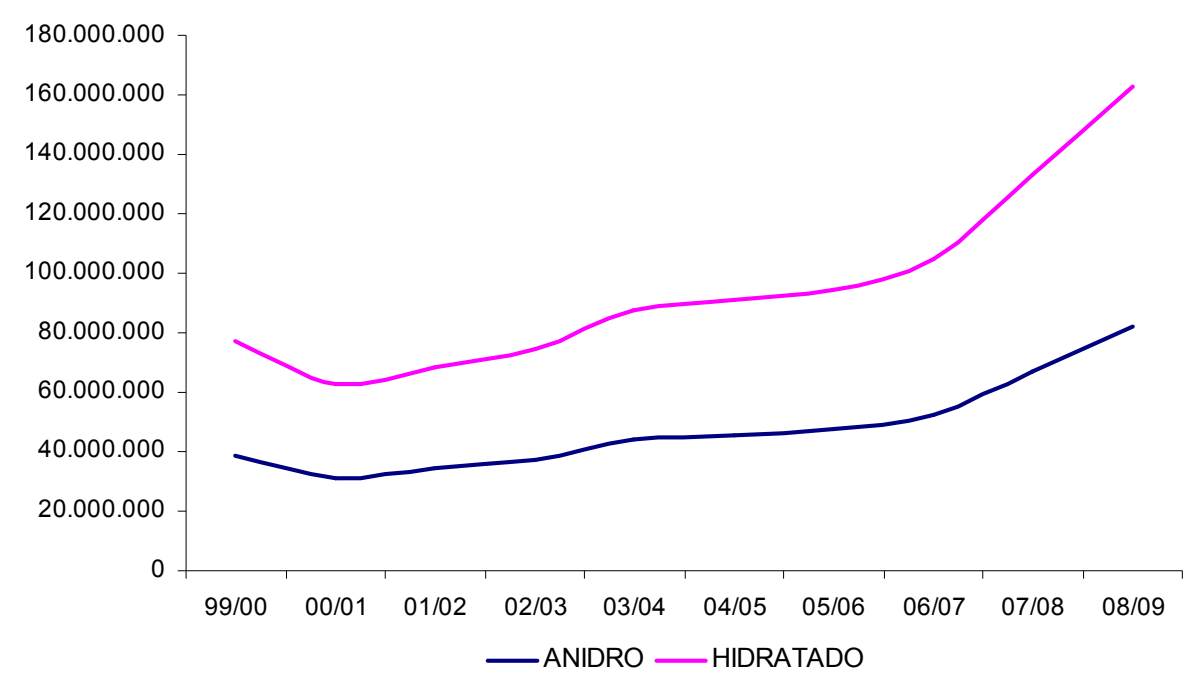

Fonte: ÚNICA ${ }^{13}$.

No que tange aos competidores do etanol, conforme já foi discutido anteriormente no Macroambiente Clima, se observa também uma forte concentração de mercado e segue uma tendência natural de uma concentração ainda maior em virtude do maior rigor tributário e fiscal, além do aumento considerável nos custos de distribuição. Por outro lado, é possível que o etanol tenha se configurado uma barreira de entrada adicional para o ingresso de novos e grandes competidores internacionais no país. Isso se justificaria por ser o único país do mundo com a tecnologia dos motores flex fuel assim como o único a ter efetivamente o etanol como combustível alternativo à gasolina. De acordo com Porter (2004) as barreiras de entrada, neste caso específico, poderiam ser atribuídas a "curva de aprendizagem ou de experiência" dos demais distribuidores, ou seja, o fato dos demais distribuidores estarem no país há muitos anos e terem enfrentando os ciclos do etanol no passado e, atualmente, constituem um diferencial relevante ao novos competidores internacionais que podem não conhecer a dinâmica do produto, por exemplo; "acesso favorável às matérias-primas", ou seja, "as empresas estabelecidas podem ter fechado as fontes mais favoráveis e/ou controlado as necessidades previsíveis com antecedência a preços que refletiam uma demanda menor

\footnotetext{
${ }^{12}$ Período se inicia em abril e vai até março do próximo ano

${ }^{13}$ Disponível em $<<$ http://www.unica.com.br/> acessado em 24 jun. 2011.
} 
do que a atualmente existente" (Porter, 2004.p. 11) e "acesso aos canais de distribuição".

Em relação ao cenário tecnológico se observa duas tendências principais das quais poderão influenciar de alguma maneira o ambiente dos distribuidores de combustíveis: (1) pressão cada vez maior para diminuição de emissões de $\mathrm{CO}_{2}$ na atmosfera o que incentivará o desenvolvimento dos denominados biocombustíveis - ou seja, combustível não originário do petróleo (Birol 2007); (2) avanços tecnológicos no desenvolvimento de motores automotivos capazes de rodar com vários combustíveis (ANFAVEA, 2006).

Birol (2007) estabeleceu dois cenários para a demanda energética mundial até o ano de 2030 e conclui que as pressões por diminuição de emissões de CO2 irão aumentar significantemente forçando sociedade, governo e as empresas a repensarem em fontes alternativas menos poluentes. $\mathrm{O}$ autor, neste sentido, acredita que haverá uma redução gradativa do consumo dos combustíveis originalmente fósseis para outras fontes renováveis e menciona que o Brasil e os Estados Unidos continuarão a liderar o ranking dos maiores produtores e consumidores dos denominados biocombustíveis.

Acredita também que o etanol na perspectiva atual não é sustentável por haver forte correlação com aumento dos preços dos alimentos, mas salienta possibilidade de se avançar tecnologicamente em pesquisas para a geração de energia de segunda geração em escala comercial.

Neste mesmo pensamento Kamimura e Sauer (2008) concluem que para atender à demanda interna do etanol em 2020 seria necessário utilizar $26 \%$ de toda área destinada à agricultura no país para plantação de cana-de-acúçar o que certamente resultaria no aumento dos preços dos alimentos e provavelmente da inflação.

Para Szklo et al (2007) dificilmente o etanol hidratado se configuraria como um substituto à gasolina mundial. A primeira implicação seria a necessidade de desenvolver novos motores para o funcionamento do carro flex fuel em países frios, especificamente. Os autores mencionam que alguns testes indicam que países de clima frio dificilmente o etanol hidratado teria um bom desempenho. Além disso, não acredita 
que será possível atender a demanda global por etanol hidratado sem comprometer outros setores da economia como o preço dos alimentos, por exemplo. Os autores acreditam, porém, que o ideal seria o uso do etanol como aditivo a gasolina até a proporção de $30 \%$ o que ajudaria a economizar dez milhões de barris por dia de petróleo.

A ANFAVEA (2006) prevê que o futuro próximo será o desenvolvimento de carros capazes de rodar com vários combustíveis a fim de atender às questões ambientais (GNV, etanol, gasolina, células de combustível e motores híbridos ${ }^{14}$ ). O órgão destaca, porém, que a versão dos carros híbridos tem um custo super elevado, uma manutenção complexa e relaciona a dificuldade para reciclagem das baterias sendo assim dificilmente se configuraria uma forte tendência. Já na ilustração 4, é possível observar a compatibilidade do etanol com todas as tecnologias existentes o que pode configurar uma grande oportunidade para o produto. Mas, o órgão salienta que apesar de o etanol parecer a solução mais racional para o Brasil, o órgão demonstra preocupação com falta de competitividade do produto em alguns períodos do ano como também em algumas regiões do país. Sendo esse um problema a ser trabalhado fortemente para consolidação do etanol.

\footnotetext{
${ }^{14}$ Motor hibrido é aquele que possui um motor de combustão interna normalmente a gasolina e um motor eléctrico que permite reduzir o esforço do motor de combustão.
} 


\section{Ilustração 4 - compatibilidade tecnológica do etanol com outros combustíveis automotivos}

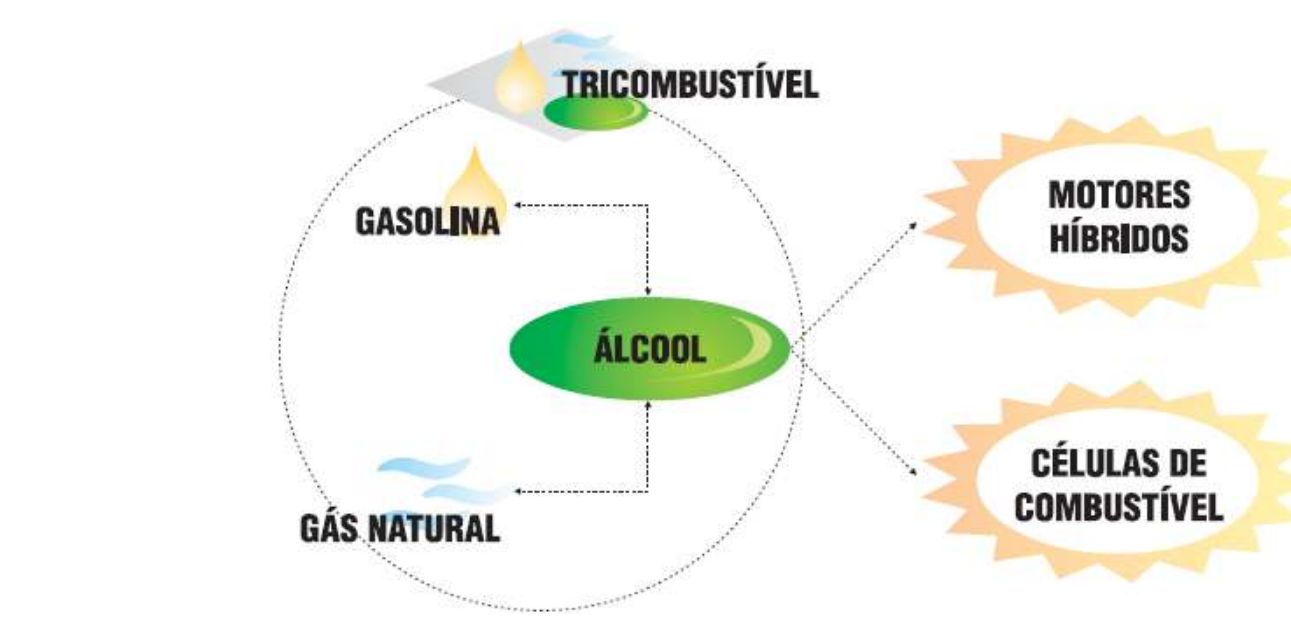

Fonte: ANFAVEA (2006, p. 40)

O ambiente operacional se configura aqui de extrema relevância para os distribuidores de combustíveis, visto que os biocombustíveis é uma realidade, e, provavelmente, sem volta. Vale lembrar que o cenário futuro, apesar de muitas incertezas é esperado avanços tecnológicos capazes de colocar o combustível fóssil como mais uma opção energética e não mais como o principal produto. $\mathrm{O}$ que poderá implicar em um novo ambiente, do qual ainda parece impossível de imaginar ainda, contudo, os distribuidores necessitam estar atentos a esse processo a fim de assegurar sua própria sobrevivência.

\subsection{Evolução competitiva dos distribuidores de combustíveis}

O termo evolução deve ser compreendido, nesta pesquisa, como a relação entre os distribuidores de combustíveis, os seus concorrentes, clientes, fornecedores e as possíveis implicações entre essas relações ao longo dos anos. O contexto competitivo será abordado através das teorias propostas por D'aveni (1995). Entende-se por concorrentes, os demais distribuidores de combustíveis; como clientes, os postos de 
combustíveis (revenda) e como fornecedores, as usinas de etanóis e as refinarias de derivados de petróleo.

Lembrando que a legislação atual obriga aos postos de combustíveis (revenda) a comprar combustíveis exclusivamente por meio de um distribuidor com autorizado pela ANP. Como também os postos que ostentam a marca de uma distribuidora específica deverá comprar exclusivamente produtos deste distribuidor. Não é permitido aos postos de combustíveis comprarem diretamente das usinas, nem das refinarias ou importar os combustíveis diretamente.

D'aveni (1995) ao observar a evolução de diversas indústrias pode constatar que as organizações estão sendo expostas a ambientes cada vez mais competitivos. O autor classifica esses ambientes como hipercompetitivos e o caracteriza por uma concorrência agressiva e ciclos de produtos cada vez mais curtos propiciando um ritmo acelerado na inovação tecnológica. Kim e Mauborgne (2005. p. 8) afirmam que a implicação desse ambiente mais competitivo traz conseqüências como a “... comoditização acelerada de produtos e serviços, a intensificação das guerras de preços e encolhimento das margens de lucro".

O que parece inegável, é que as organizações estão enfrentando um ambiente muito diferente do que existia nas décadas anteriores. Prahalad e Hamel (2005) destacam que o futuro não poderá mais ser considerado uma repetição ou extrapolação do passado e que os mercados de hoje serão inteiramente transformados por novos produtos/serviços e/ou por novas demandas sociais. O que é considerado um mercado de nicho será definitivamente um mercado de massas do amanhã.

Para Kotler e Caslione (2009) os ambientes hipercompetitivos ou turbulentos, como denominam os autores, é determinado por um conjunto de fatores que somados levam a constantes mutações no ambiente, manobras competitivas intensas que exigem dos competidores uma agilidade cada vez maior em suas ações e esse cenário implica em vantagens insustentáveis. Neste sentido afirmam que:

“ ... a hipercompetição é determinada pela globalização, por maior fragmentação das 
preferências dos clientes, pela desregulamentação e pela inovação em modelos de negócios - fatores que, em conjunto, contribuem para o desequilíbrio estrutural, para a queda das barreiras de entrada dos mercados e para a destituição dos líderes setoriais."

Kotler e Caslione (2009. p.31)

Para D'aveni (1995) existem quatro dimensões competitivas na era da hipercompetitividade:

1. Custo e Qualidade: Oferta de diferentes níveis de qualidade e diferentes opções de preços. Quando a qualidade não é o principal fator de competição as organizações são forçadas a ingressarem em guerras de preços constantes. Com a intensificação da hipercompetição se observa uma tentativa de ampliar o portfólio de produtos em diferentes níveis de qualidade e serviços buscando assim a diferenciação dos demais concorrentes. É comum nesta dimensão se tornar um movimento constante entre elevação da qualidade e redução dos preços. Salienta o autor que essa é uma estratégia rapidamente copiada pelos concorrentes e quando todos atingem esse patamar passa a ser necessário um esforço cada vez maior das organizações para romper esse ciclo. Para os distribuidores de combustíveis se configuram como produtos diferenciados os combustíveis aditivados ou gasolina de alta octanagem ${ }^{15}$; os lubrificantes de base sintética e uma oferta mais completa para as lojas de conveniências. E o confronto entre custo e qualidade poderia se dar na oferta desses produtos por preços cada vez mais baixos.

2. Tempo (timing) e Conhecimento (know how): D'aveni (1995) salienta que a utilização desta dimensão poderá ser uma das saídas utilizadas pelas organizações para fugir do ciclo competitivo de preço e qualidade ingressando em novos mercados ou lançando novos produtos. E, neste

\footnotetext{
${ }^{15}$ Octanagem é o índice que mede a resistência de detonação dos motores do ciclo Otto. Quanto maior a octanagem maior é a será a resistência de detonação do motor. E paras os carros que requerem gasolinas com maior octanagem essa pode ser mais econômica do que a gasolina regular. Salientando que a gasolina comum no Brasil tem 87 octanas e a maior octanagem do país é oferecida pela BR Distribuidora com 97 octanas.
} 
caso, torna-se essencial o pioneirismo das ações o que irá colocar a organização sempre à frente em conhecimento da concorrência. $\mathrm{O}$ ciclo hipercompetitivo dessa dimensão se estabelece com ritmo cada vez mais frenético de imitação e melhorias realizadas pelos concorrentes até que o pioneiro seja superado. A realidade dos distribuidores de combustíveis pode-se mencionar que a Shell foi a primeira a introduzir no país o conceito de lojas de conveniência na década de 1990 e rapidamente foi copiada por todos os demais distribuidores; mas em 2009 é a Ipiranga, entre os bandeirados, que detém o maior número de lojas de conveniência e a Esso que oferece um portfólio de produtos mais amplo ao consumidor e a Shell detém a melhor performance entre faturamento e metro quadrado de acordo com o Sindicom (2010).

3. Fortalezas: Quando as duas dimensões parecem esgotadas as organizações passam a buscar outras fontes de vantagens capazes de neutralizar os competidores. E, neste sentido, as organizações buscam criar e evidenciar uma barreira em torno de uma fortaleza, seja ela de caráter geográfico, segmento industrial ou ainda de segmento de mercado ou de produto; com isso tentam se isolar da competição baseada nas dimensões anteriores (preço e qualidade; imitação e inovação). O que se percebe dentro da realidade dos distribuidores de combustíveis, claramente, é que BR Distribuidora com apelo nacionalista está presente todos os estados, conta com a maior e vasta rede de bases de distribuição do país dispondo assim de uma ampla e bem distribuída rede de distribuição geográfica.

4. Reservas Financeiras: as reservas financeiras podem ser utilizadas de duas maneiras principais: as empresas com maior aporte podem utilizar desta vantagem para desgastar ou até mesmo fazer minar as forças de concorrente menor; a segunda opção é a formação de alianças formais entre empresas concorrentes a fim de unir forças contra um concorrente em potencial ou ainda ampliação de fortalezas. Neste quesito, é possível citar a joint venture entre a Shell e a Cosan, O Grupo Ultra e a BR distribuidora como também a aliança entre os distribuidores Ale, Agip, Sat. 
Sendo assim, após compreender o ambiente Clima, Solo e Operacional dos distribuidores de combustíveis fica fácil afirmar que o ambiente destas organizações vem se tornando cada vez mais competitivo. No (Quadro 3) estão relacionados a transição deste ambiente de uma competição de baixa intensidade para uma competição de alta densidade, ou hipercompetitiva, como descreve D'aveni (1995). O autor considera ainda que todos os ambientes da atualidade e de qualquer segmento tendenciam para uma competição extrema caracterizado pela concorrência perfeita, pela existência de muitos protagonistas, não havendo lucros anormais e a oferta de produtos com alta qualidade e baixos preços. Em relação aos distribuidores de combustíveis não é possível afirmar que eles tenham atingido esse nível de competição e por este motivo não será explorado nesta pesquisa. A seguir através do (Quadro 2) será caracterizado cada nível da competição definido por D'aveni (1995):

2 - Níveis de Competição dos Distribuidores de Combustíveis

\begin{tabular}{|l|c|c|c|}
\hline Níveis da competição & $\begin{array}{c}\text { Tendências nos } \\
\text { Lucros }\end{array}$ & Tipo de Competição & $\begin{array}{c}\text { Características da } \\
\text { Competição }\end{array}$ \\
\hline Baixa Densidade & Excessivos & $\begin{array}{c}\text { Monopólio } \\
\text { Monopólio Legal }\end{array}$ & $\begin{array}{c}\text { Baixa ou nenhuma } \\
\text { Competição }\end{array}$ \\
\hline Moderada & Sustentáveis & Oligopólio & Evita-se a competição \\
\hline Alta densidade & Intermitentes ou baixos & $\begin{array}{c}\text { Shumpeteriana } \\
\text { (diversos protagonistas) }\end{array}$ & Hipercompetição \\
\hline Extrema & Não há lucros anormais & Muitos protagonistas & Concorrência Perfeita \\
\hline
\end{tabular}
Fonte: Adaptado D'aveni (1995)

O autor confere a competição de baixa densidade o monopólio ou quase monopólios como também conchavos e acordos entre concorrentes que visem limitar a agressividade da concorrência por este motivo as organizações conferem lucros excessivos em suas operações. Na competição moderada, os lucros ainda são altos e sustentáveis ao longo prazo, as empresas evitam a competição direta através da segmentação de mercados em que cada um dos competidores assuma a liderança em um segmento específico, podendo haver, contudo uma pequena superposição entre os segmentos ou nichos de mercado. No que tange a competição de alta densidade, ou hipercompetitiva, se observa que os concorrentes se agridem mutuamente tentando enfraquecê-los, as organizações buscam superar umas as outras em alguma das quatro dimensões competitivas (custo e qualidade, timing e know how, fortalezas e reservas 
financeiras) as vantagens passam a ser temporárias e os lucros são intermitentes ou baixos.

Quadro 3 - Fases da Competição dos Distribuidores de Combustíveis.

\begin{tabular}{|c|l|c|}
\hline Fases & \multicolumn{1}{|c|}{ Cenário } & $\begin{array}{c}\text { Nível de } \\
\text { Competição }\end{array}$ \\
\hline $\begin{array}{c}\text { Fase 1: } \\
\text { Mercado regulamentado }\end{array}$ & $\begin{array}{l}\text { Competição e oferta limitada; } \\
\text { Preços regulamentados em toda cadeia; } \\
\text { O etanol surge como produto substituto à gasolina; } \\
\text { O etanol se torna o principal combustível automotivo no } \\
\text { país, mas perde mercado quando o petróleo retoma } \\
\text { patamares de preços mais competitivos que o próprio } \\
\text { produto. }\end{array}$ & $\begin{array}{c}\text { Competição de } \\
\text { baixa densidade. }\end{array}$ \\
\hline $\begin{array}{c}\text { Fase 2: } \\
\text { Início da }\end{array}$ & $\begin{array}{l}\text { Mercado em processo de desregulamentação; } \\
\text { Início da competição; } \\
\text { Prȩos dos combustiveis ainda permanecem elevados; } \\
\text { Oferta em crescimento; } \\
\text { Crise do açúcar. }\end{array}$ & $\begin{array}{c}\text { Competição de } \\
\text { baixa densidade } \\
\text { à moderada }\end{array}$ \\
\hline $\begin{array}{c}\text { Furge 3: } \\
\text { motores flex fuel. }\end{array}$ & $\begin{array}{l}\text { Mercado completamente desregulamentado; } \\
\text { Oferta livre; } \\
\text { Cresce o número de competidores; } \\
\text { Perda de rentabilidade; } \\
\text { Cresce a ilegalidade no setor; } \\
\text { O volume de vendas do etanol aumenta ano após ano. }\end{array}$ & $\begin{array}{c}\text { Competição } \\
\text { moderada com } \\
\text { leve tendência a } \\
\text { alta densidade }\end{array}$ \\
\hline $\begin{array}{c}\text { Fase 4: } \\
\text { Mercado atual }\end{array}$ & $\begin{array}{l}\text { Excesso de oferta; } \\
\text { Competição acirrada; } \\
\text { O etanol passa a representar, em 2009, 39\% das vendas do } \\
\text { ciclo Otto no país, mas em algumas regiões ultrapassa 50\% } \\
\text { de participação. } \\
\text { Governo impóe rígidas regras fiscais e de controle ambiental. }\end{array}$ & $\begin{array}{c}\text { Competição de } \\
\text { alta densidade }\end{array}$ \\
\hline
\end{tabular}

No que tange a análise dos distribuidores de combustíveis a fase 1 descrita do (Quadro 3) corresponde o período do final da década de 1970 ao final da década de 1980. Esse período é caracterizado pela crise do petróleo e a decisão de promover o etanol como produto substituto à gasolina em quatro etapas:

Primeira Etapa: adição de etanol anidro as gasolinas até o limite máximo de $25 \%$.

Segunda Etapa: Conversão dos veículos existentes movidos à gasolina para o uso do etanol hidratado.

Terceira Etapa: fabricação de veículos projetados para rodar exclusivamente com etanol. 
Quarta Etapa: E desenvolver estudos para carros híbridos - com tecnologia carros flex fuel.

Silva e Fischetti (2008) comentam que as primeiras três etapas do projeto até a fabricação dos carros movidos exclusivamente a etanol foi um sucesso e alcançou resultados acima do esperado. Afirmam ainda que, no ano de 1982 foram vendidos mais de 4 mil veículos movidos exclusivamente a etanol. Em 1986, 95\% dos carros produzidos no país eram movidos exclusivamente a etanol consumindo 12 bilhões de litros de etanol.

É importante lembrar, que esse é um período em que a oferta e os preços eram era controlados e estipulados pelo governo. A Petrobras detinha o monopólio do setor no que tange a produção, refino e importação dos derivados de petróleo assim como a estocagem, a importação (quando necessário) e a comercialização do etanol para os distribuidores de combustíveis. Por estas razões, a competição entre os distribuidores de combustíveis pode ser descrita como inexistente ou de baixa densidade o que permitiu lucros excessivos.

McConell e Brue (2001) definem monopólio como um único ou um pequeno grupo de vendedores, que por ser tão pequeno são capazes de influenciar a oferta total. Afirmam ainda que pelo fato dos monopolistas não serem regulados pela concorrência, ao restringir a oferta podem determinar preços superiores aos que poderiam ser praticados em condições em que prevalece a concorrência. Desta forma, os autores concluem que "a produção restrita e os preços e lucros altos conflitam diretamente com os interesses do consumidor". McConell e Brue (2001, p. 69)

Neste sentido, se observa que a relação dos distribuidores de combustíveis era resumida a Petrobras como único fornecedor de derivados de petróleo. Em relação ao etanol, era também a Petrobras a responsável pela negociação direta com usineiros e a comercialização do etanol para toda a cadeia. Havia também um número reduzido de competidores e de acordo com o SINDICOM (2003), esse período foi marcado pela expansão da atuação dos distribuidores para outras regiões do país, ao passo que aumentava a frota de veículos e obviamente a demanda por combustíveis e derivados de petróleo. 
É importante salientar o contexto político e econômico do país neste período para que se compreender melhor a própria evolução competitiva dos distribuidores de combustíveis. A década de 1980, foi marcada por um período de alta inflação no país, que alcançou três dígitos em um único ano. Adoção de medidas macroeconômicas emergenciais para tirar o país da crise, sucessão de política monetária falidas; queda vertiginosa do Produto Interno Bruto (PIB) entre o período de 1981 a 1984, de acordo com o IPEA (2010) neste período o PIB per capita cai de 2.117 dólares para 1.568 dólares, enquanto o índice de preços ao consumidor subiu de $95,62 \%$ ao ano para $242,23 \%$. Por este motivo, a década de 80 , é considerada uma década perdida por muitos historiadores e economistas. De fato houve um retrocesso econômico no país assim como em outros países da America Latina. Em mais uma tentativa de recuperação econômica em 1986 o presidente José Sarney implementa uma série de medidas para o combate da inflação. Põe fim a moeda (Cruzeiro) e cria o Cruzado congela preços e salários. Há pequenas e sutis melhorias econômicas, mas não foram suficientes para promover o crescimento do país.

O que se observa também neste período, o fim da crise do petróleo e a queda no preço do barril da commodity. Em paralelo, o etanol supera as expectativas de vendas e obriga o governo a importar o produto para garantir o abastecimento interno. Criandose assim uma incoerência com as idéias iniciais do programa que consistia em diminuir o dispêndio em importação com combustíveis. Mesmo com as importações chegou a faltar inúmeras vezes o produto para o consumidor final (Silva e Fischetti (2008)).

O governo necessitado frear o consumo do etanol deixou de dar incentivos fiscais para compra de carros movidos exclusivamente a etanol. Silva e Fischetti (2008) relembram que o governo investiu cerca de 7 bilhões de dólares no período de 1975 a 1989 incluindo ainda o financiamento das destilarias autônomas que chegava a cobrir cerca de $80 \%$ do investimento fixo. Com a falta de incentivos, a crise do abastecimento do etanol e o preço da gasolina mais competitivo que o etanol a indústria automobilística retoma a produção de veículos movidos exclusivamente a gasolina e aos poucos o etanol perde participação nas vendas. A União da Indústria da Cana-de-açúcar (UNICA) afirma que a participação anual dos veículos movidos exclusivamente a etanol foi caindo vertiginosamente até atingir 1.02\% na frota nacional, em 2001. 
O programa de promoção ao etanol como produto substituto à gasolina entra em descrédito e o governo percebe a necessidade de promover mudanças econômicas estruturais, dando início assim a década de 1990 e a fase 2 de competição do setor.

Assim a fase 2 (década de 1990), no cenário econômico do país, é um período caracterizado pelo início do processo de privatização das estatais como telecomunicações, mineração, energia elétrica e bancos estaduais que propiciou a abertura das fronteiras do país para investimentos estrangeiro. Assim como também a implementação de políticas fiscais, orçamentária e monetária com o surgimento do Plano Real. Vale salientar, que com a estabilidade econômica obtida com o Plano Real houve consideráveis melhorias no que tange os índices sociais. De acordo com IPEA (2010) as principais melhorias notadas no período foram: o maior acesso de bens duráveis pelas famílias de baixa renda; maior poder de compra com o salário mínimo real; maior disponibilidade de crédito consignado no mercado o que possibilitou uma forte redução do risco bancário ao consumidor; aumento das exportações e aumento do consumo interno.

Para os distribuidores de combustíveis a grande mudança se dá com o início do processo de desregulamentação do setor. O governo impõe uma agenda para liberação dos preços dos combustíveis incluindo o diesel: a primeira etapa, libera os preços entre as usinas e refinarias para os distribuidores de combustíveis e, a segunda etapa, prevê a liberação dos preços entre os distribuidores de combustíveis e os postos de combustíveis. Com isso, os postos de combustíveis se tornam "livres" para decidir o preço final para o consumidor. Maistro (2002) destaca os períodos em que foi realizado o processo de liberação dos preços por produto: em 1996 foi a gasolina; em 1997 é o etanol anidro; em 1999 foi a vez do etanol hidratado; Contudo, lembra a autora, que somente no final de 2002 é que os preços são inteiramente liberados em toda a cadeia.

Outro ponto, também, muito importante e lembrado por Pinto e Silva (2004) é a Portaria n. 362, em 1993, do Ministério de Minas e Energia (MME) que regulamenta a participação dos postos de combustíveis denominados bandeiras brancas. De acordo com os autores, antes de esta portaria ser regulamentada os contratos estabelecidos entre os distribuidores e os postos de combustíveis permeavam a exclusividade de 
compra com uma única distribuidora. Afirmam Pinto e Silva (2004, p.2) "A mudança dessa estrutura foi, sem dúvida, um fator importante para o estabelecimento de uma nova dinâmica de formação de preços, governada por forças de mercado".

No contexto internacional, Maistro (2002) destaca duas frentes importantes que impulsionaram a retomada da quarta fase do programa do governo para o etanol: (1) período turbulento e instável no Oriente motivando uma nova subida de preço do barril do petróleo e a (2) queda do preço internacional do açúcar forçando ao governo a buscar recursos para diversificar a utilização da cana-de-açúcar excedente. Não se pode esquecer, porém que a década de 1990 foi palco de catástrofes de grandes proporções em vários países do mundo, motivando a intensificação dos apelos por grupos ambientais para redução da emissão de $\mathrm{CO}_{2}$ na atmosfera.

Para Silva e Fischetti (2008), a conjunção do bom crescimento econômico deste período mais esses três fatores contribuíram para a redefinição e reafirmação do programa etanol como produto substituto à gasolina; culminando assim, em uma nova sinergia entre a indústria automotiva, indústria sucroalcoleira e os distribuidores de combustíveis para tornar o projeto do carro flex fuel uma realidade.

A década de 1990, fica definitivamente marcada pelo inicio do processo de desregulamentação. E, com isso se dá o início a competição entre os distribuidores, pois a Petrobras deixa de ser o único fornecedor de produtos e derivados de combustíveis incluído o etanol o que obriga aos distribuidores a disputarem pela compra dos produtos nas refinarias de petróleo assim como nas usinas de etanóis. Por outro lado, com a regulamentação do posto bandeira branca, a disputa por clientes também se intensifica entre os distribuidores de combustíveis.

O SINDICOM afirma que esse período foi um dos mais difíceis do setor em virtude da falta de coordenação governamental, a falta de clareza das ações como também muitas brechas na legislação o que favoreceu o ingresso de empresários com práticas ilícitas prejudicando todo o setor, diante deste contexto o órgão afirma: 
Em 1992, o Departamento Nacional de Combustíveis (DNC) ${ }^{16}$ tornou menos exigente o processo de abertura de empresas distribuidoras. As mudanças ocorreram, todavia sem que fossem estabelecidos mecanismos de proteção que preservassem o mercado das ações predatórias de empresários sem compromisso com a estabilidade ou com a sociedade. No decorrer de 1993, foi possível observar uma expansão inusitada do número de empresas autorizadas a funcionar como distribuidores de combustíveis. De pouco mais de 10 chegou-se a quase 400 distribuidores registrados.

SINDICOM (2003, p.36)

A fase 2, pode ser considerada como um período de redefinição do setor como um todo. Pode ser considerada ainda uma das fases mais importantes e significativas para os distribuidores de combustíveis, uma vez que possivelmente esses agentes tiveram que desenvolver novas ferramentas competitivas a fim de assegurar sua própria existência.

A fase 3, compreende os anos entre 2000 a 2005; é considerado o período pósdesregulamentação dos preços e a articulação governamental para lançamento do carro flex fuel.

Sendo assim em 2003, é lançado o primeiro carro de motor flex fuel, sendo a Volkswagen a primeira a lançar um veículo flex fuel - o Gol Total Flex. É possível acompanhar através do (Anexo I) a evolução das vendas veículos movido exclusivamente a gasolina, exclusivamente a etanol e os carros flex fuel. Entre os anos de 2004 e 2005 as vendas deste veículo cresceram quase 248\%, saltando de 328 mil veículos vendidos para 812 mil veículos respectivamente. Desta forma, já no ano de 2005, a quantidade de veículos vendidos de motores flex fuel supera o total de veículos vendidos movidos exclusivamente à gasolina.

Para Santos et al (2010), em 2014 os carros de motores flex fuel representarão 98,4\% do total da frota circulante no país e o etanol deverá representar $43,9 \%$ do volume total de combustível consumido no país. Os autores salientam que a penetração do etanol não é igual em todo o território brasileiro e que o produto obterá uma maior penetração quando se mantiver o preço $70 \%$ menor que o preço da gasolina. De acordo com Abramovay (2008), o país já contava no fim de 2005 com mais de 60 modelos com esta

\footnotetext{
${ }^{16}$ Atualmente essas atividades são atribuídas a ANP.
} 
tecnologia, com 10 montadoras produzindo motores flex fuel, como também já existiam ônibus, motocicletas e até mesmo aviões movidos a etanol.

Observando a outra ponta do setor, o mercado desregulamentado propiciou o aumento do número de postos bandeira branca, conforme demonstrou o (Gráfico 2), e esta realidade favoreceu o aumento da competição entre os distribuidores de combustíveis, assim afirmam Pinto e Silva (2004). Por outro lado, a Fecombustíveis (2011) relembra que a aumento da competição promovido pelo aumento considerável dos postos denominados bandeira branca e pelo aumento do número de pequenos distribuidores de combustível fez emergir uma indesejável realidade de crimes contra o consumidor, contra o estado e o próprio setor. O órgão resume a realidade da época afirmando que:

A adulteração de combustíveis no Brasil tornou-se um problema sério. Inúmeros motoristas sofreram prejuízos patrimoniais enormes, em busca da economia de alguns centavos na hora de abastecer. A banda podre do mercado usou solvente, etanol, água, metanol e engenhosos mecanismos para enganar fiscais, acionando dispositivos remotos que liberavam combustível conforme ${ }^{17}$ somente quando um agente chegava. Sem falar nos postos $\operatorname{clones}^{18}$, que imitavam bandeiras tradicionais.

Através da (Ilustração 5), é possível comprovar esse cenário. O índice de combustíveis fora das especificações da ANP (produto não conforme) para o etanol apresenta um considerável crescimento no período de 2000 a 2003. No ano de 2000, o percentual de etanol não conforme foi e $7.3 \%$ em 2000 , em 2001 salta para $10.3 \%$ e ultrapassa os $12 \%$ em 2002. Já na gasolina o cenário é mais positivo no mesmo período se observa uma queda no índice de um pouco mais de dois pontos percentuais para cada ano. $\mathrm{O}$ diesel apesar de estar demonstrado na ilustração 5 não será explorado, pois não configura objeto de análise nesta pesquisa.

\footnotetext{
${ }^{17}$ Combustível conforme significa dentro das especificações estipuladas pela ANP.

${ }^{18}$ Postos clones se referem quando os revendedores dos postos bandeira branca utilizavam de mecanismos para ficarem parecidos com os postos que representavam as marcas dos postos bandeirados, como o uso do padrão de cores e/ou uniformes dos frentistas, e assim, enganando ou pelo menos dificultando a percepção do consumidor.
} 
Ilustração 5 - Evolução da não conformidade dos combustíveis no Brasil.

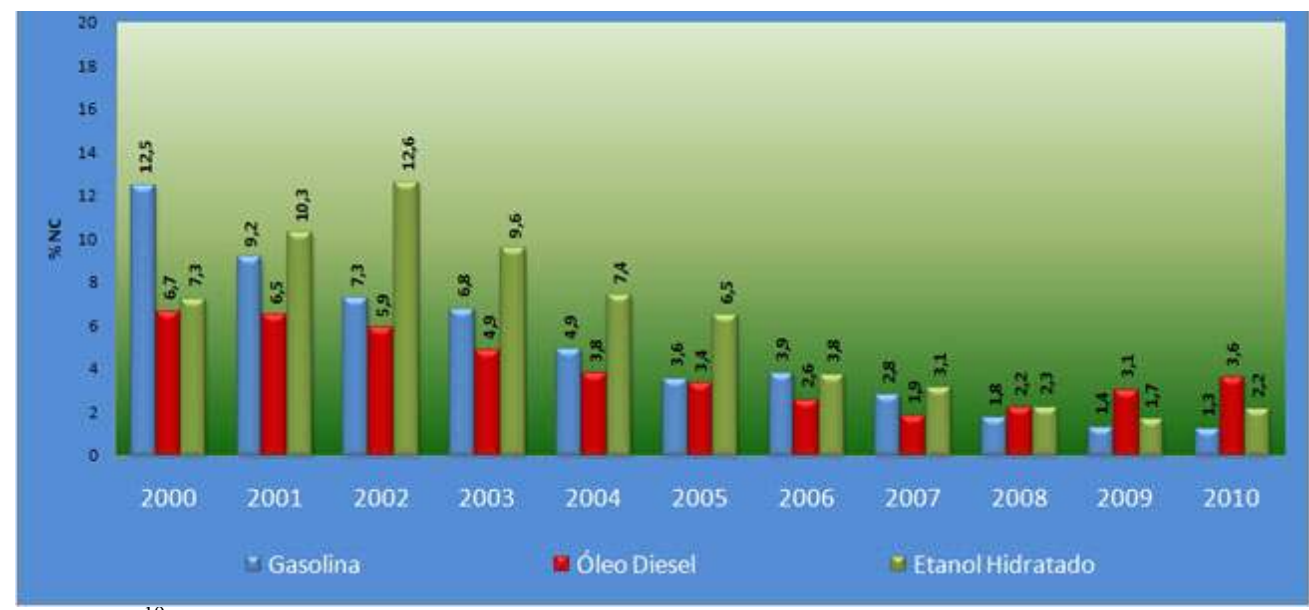

Fonte: $\mathrm{ANP}^{19}$

Para Pinto e Silva (2004), as conseqüências desse cenário é a inviabilidade competitiva a longo prazo, distorções no funcionamento do mercado que prejudicam o consumidor e o contribuinte, dessa forma, reduzindo a arrecadação de impostos dos estados e da federação por fim, estimulam a corrupção e o crime organizado.

Contudo, não se pode negar que o ambiente, diante deste cenário, não tenha se tornado mais competitivo. E, como descreve Kim e Mauborgne (2005), as primeiras evidências desse processo, é a redução das margens dos agentes do setor. Dalmonech et al (2005) observaram que nos anos de 2003 e 2004 houve um avanço nas margens dos distribuidores de combustíveis em relação as margens da revenda e uma redução clara na margem dos revendedores (postos de combustíveis).

Conforme, a (Ilustração 5), é possível observar que a variação média de margens dos distribuidores de combustíveis se comparando janeiro de 2003 e janeiro de 2004, uma média de 6,6\%; com um aumento da margem média de $24.8 \%$ para $31.4 \%$. O contrário se observa do lado dos postos de combustíveis, denominado pelos autores como revenda. No mesmo período, se observa uma variação de margem negativa de $6.6 \%$, com perda de $75.2 \%$ para $68.6 \%$ de margem em janeiro de 2004 .

\footnotetext{
19 Disponível em <http://www.anp.gov.br/> acessado em 24 jun. 2011
} 
Ilustração 6 - Margem bruta dos distribuidores e postos de combustíveis (revenda).

Distribuição

Revenda

\begin{tabular}{cccccccc} 
& \multicolumn{3}{c}{ Distribuição } & \multicolumn{3}{c}{ Revenda } \\
\hline \multirow{2}{*}{ Bandeiras } & jan/03 & jan/04 & Margem & jan/03 & jan/04 & Mariação de \\
Petrobrás & $19,0 \%$ & $26,1 \%$ & $7,1 \%$ & $81,0 \%$ & $74,0 \%$ & $-7,1 \%$ \\
Ipiranga & $22,4 \%$ & $30,2 \%$ & $7,8 \%$ & $77,6 \%$ & $69,8 \%$ & $-7,8 \%$ \\
Esso & $19,2 \%$ & $31,1 \%$ & $11,9 \%$ & $80,8 \%$ & $68,9 \%$ & $-11,9 \%$ \\
Texaco & $32,4 \%$ & $32,5 \%$ & $0,1 \%$ & $67,7 \%$ & $67,5 \%$ & $-0,1 \%$ \\
Shell & $30,9 \%$ & $37,0 \%$ & $6,1 \%$ & $69,1 \%$ & $63,0 \%$ & $-6,1 \%$ \\
\hline Média & $24,8 \%$ & $31,4 \%$ & $6,6 \%$ & $75,2 \%$ & $68,6 \%$ & $-6,6 \%$ \\
\hline-
\end{tabular}

Fonte: Dalmonech et al (2005, p.6)

Diante da ilustração 6, é possível concluir que os distribuidores de combustíveis objetivando assegurar a própria rentabilidade avançaram nas margens dos postos de combustíveis. E estes, por serem obrigados a cumprir contratos de exclusividade de compra não teriam outra saída a não ser a redução da própria margem para competir com os postos bandeira branca, que normalmente, praticavam preços de bomba (preço para o consumidor) abaixo do que os praticados pelos postos bandeirados.

Dalmonech et al (2005) sugerem que neste período, haveria acordo de cavalheiros selados entre os distribuidores de combustíveis no preço de venda para os postos de combustíveis. Com esta decisão a guerra de preços se concentrava exclusivamente para os postos de combustíveis que acabam sofrendo a pressão do ambiente diretamente.

É neste período que se observa também uma tentativa dos distribuidores de combustíveis se diferenciarem em algum atributo que seja específico à organização em resposta a turbulência do ambiente. A BR reforça seu apelo nacionalista, A Ipiranga a de melhor oferta, a Esso de melhor tecnologia e inovação, a Shell reforça a imagem de alta qualidade e explora a parceria com Ferrari (Sindicom 2003).

E, por último, a fase 4 que compreende o período de 2006 a 2009. Conforme discutido anteriormente se observou neste período uma atuação mais firme do governo para combate da ilegalidade, o recorde nas vendas dos carros flex fuel e volume consumido do etanol hidratado. Os dois primeiros anos desta fase (2006 e 2007), se observa que a 
competição chegou ao ponto máximo e o que condiciona nos dois anos seguintes são marcados por grandes fusões entre os competidores; o que reforça ainda mais as teorias de D'aveni (1995), ao afirmar que as organizações percorrem todas as três dimensões até a exaustão e optam ou acabam sendo forçada a última dimensão - reserva financeira.

Contrapondo as fases da evolução da competição dos distribuidores de combustíveis com as quatro dimensões da competição proposta por D'aveni (1995), é possível concluir que a fase 1 desempenha a primeira dimensão competitiva (custo / qualidade), visto que é característico da concorrência monopolista; a fase 2 o acirramento da competição baseada em custo/qualidade e inicia-se a escalada para a segunda dimensão (timing/know how), é nesta fase, que se observa os distribuidores de combustíveis lançando novos produtos e serviços; já a fase 3, se observa a intensificação da segunda dimensão e se inicia a disputa na terceira dimensão (fortaleza), neste movimento cada distribuidor busca fortalecer um determinado atributo ou vantagem em relação ao competidor. A fase 4, se configura pela exaustão da terceira dimensão e é iniciada a escalada para a quarta dimensão (reservas financeiras principalmente) o que fica claro através das fusões entre os competidores observadas no período.

\subsubsection{Bons e maus competidores}

Porter (1989) salienta que as empresas estão sujeitas a enfrentar bons e maus competidores e que necessitam conhecê-los profundamente para que possa desenvolver estratégias adequadas e assim assegurar vantagens competitivas. $\mathrm{O}$ autor acredita que rivalidade entre os competidores é comumente observada na concorrência por preço, batalha de publicidade, introdução de produtos, oferta de serviços e na disputa por clientes. "A rivalidade ocorre quando um ou mais competidores sentem-se pressionados ou percebem a oportunidade de melhorar a posição.” Porter (2004, p.16).

$\mathrm{O}$ autor define oito características de um bom concorrentes. $\mathrm{O}$ mal concorrente se configura exatamente em idéias opostas. O bom competidor, segundo Porter (1989, 
p.196) é "aquele que desafia a empresa a não ser complacente, mas é m competidor com qual a empresa pode atingir um equilíbrio industrial estável e rentável sem uma guerra prolongada.” A seguir serão listadas as oito características do bom competidor:

1. De confiança e viável: significa que o competidor dispõe de recursos e capacidades suficientes para focar a empresa a buscar pela redução dos custos ou acentuar a diferenciação;

2. Pontos fracos claros e reconhecidos;

3. Compreende as regras as da concorrência da indústria. Inclusive auxilia no desenvolvimento do mercado e promove melhorias em tecnologias existentes;

4. Hipóteses realistas: compreende a indústria e sua própria posição relativa.

5. Conhecimento dos custos e fixa os preços de acordo.

6. Tem uma estratégia que melhore a estrutura industrial preservando e reforçando elementos desejáveis da estrutura da indústria.

7. Barreiras de saídas moderadas e pode oferecer impedimento viável para novos entrantes;

8. Metas reconciliáveis com as metas da empresa.

Para Nunes e Gomes (2005) a divisão entre os bons e maus competidores poderia ser resumida basicamente, pelo desrespeito ao terceiro item acima descrito por Porter (2004).

Alguns distribuidores simplesmente desrespeitaram as regras da concorrência do setor com práticas ilegais e acabaram promovendo por sua vez guerra de preços em várias cidades do país além de danos para o consumidor, entre outros efeitos. Nunes e Gomes (2005) mencionam por outro lado, que foram os próprios distribuidores que exerceram forte pressão junto ao governo para que este criasse mecanismos de defesa da concorrência. Entre algumas exigências foi aprovado pela ANP o pleito para aumentar a capacidade de armazenagem dos combustíveis como também exigência de um capital mínimo para novos distribuidores de combustíveis.

Os autores assim como Porter (2004) concluem que ambientes divididos entre bons e maus competidores não favorecem para o bom desempenho do setor. Como também 
todos os agentes envolvidos ou dependentes desse setor sofrem conseqüências que podem se tornar irreparáveis com o tempo.

\subsection{Estratégias competitivas}

O conceito sobre estratégia organizacional e estratégia competitiva são temas que foram amplamente estudados e explorados. Ansoff (1990) diferencia os termos afirmando que estratégia organizacional remete a idéia das decisões relacionadas ao tipo negócio que a empresa pretende ou não atuar. Enquanto estratégia competitiva está relacionada ao enfoque e o modo como as organizações competem para ter sucesso em um determinado negócio. Costa (2007) enfatiza que as estratégias competitivas são ferramentas utilizadas pelas organizações quando há disputa entre o mesmo públicoalvo, mesmo mercado, compradores ou consumidores; essas estratégias podem ser utilizadas de forma explicita ou implícita. Já Miles e Snow (2003) acrescentam que o sucesso da estratégia competitiva está na capacidade das organizações se adaptarem ao ambiente ao qual estão inseridas.

A estratégia competitiva dos distribuidores de combustíveis está intimamente condicionada às decisões/ações dos seus stakeholders.. O governo tem um papel extremamente importante nesse processo, por exemplo, no momento em que passa a conceder subsídios para a produção de um determinado modelo de veículo ou um produto combustível acaba influenciando a frota de veículos como também o consumo de combustíveis; o que certamente afeta de alguma maneira o volume de vendas dos distribuidores de combustíveis. Do outro lado, estão as decisões dos usineiros (fornecedores) que podem optar pela produção do açúcar e/ou etanol, que, por conseguinte, pode afetar o preço do etanol pago em toda a cadeia. Na ponta final há os proprietários dos carros de motores flex fuel que decidem que combustível abastecer de acordo com sua conveniência (por motivos ideológicos, ambientais ou econômicos).

Esse parágrafo, ilustra apenas uma parte da complexidade do setor, mas é possível perceber que os distribuidores de combustíveis estão condicionados a uma série de 
variáveis que tornam seu ambiente extremamente complexo. Observam Yamin et al (1999) que com a intensificação da competição seja ela doméstica ou global culminaram naturalmente para um olhar mais detalhado e crítico da estratégia competitiva sob as diferentes condições ambientais dos quais as organizações estão sendo pressionadas. Daí as estratégias competitivas surgem como ferramentas para as organizações atuarem, manipularem, modificarem ou reagirem às mudanças ambientais.

Durante a revisão bibliográfica sobre as estratégias competitivas percebeu-se que os modelos desenvolvidos pelos autores poderiam apresentar uma limitação para enquadrar as possíveis estratégias adotadas pelos distribuidores de combustíveis frente as profundas mudanças ambientais vividas no setor durante o período pesquisado. E como o objetivo desta pesquisa é explorar a atuação dessas organizações, o modelo apresentado por Zaccarelli e Fischmann (1994) apresenta maior flexibilidade e amplitude. Os autores identificaram trezes tipos diferentes de estratégias. São elas: oportunidades (1), desinvestimentos (2), intento (3), adaptação (4), diferenciação de produto-mercado (5), diferenciação funcional (6), inovação (7), evolução (8), reação (9), despistamento (10), cooperação (11), agressão (12) e autoproteção (13). De acordo com os autores as empresas podem adotar uma ou um conjunto de estratégias elementares ponderando claramente as estratégias opostas entre si.

Será através das estratégias identificadas pelos autores que se pretende explorar as possíveis estratégias adotadas pelos distribuidores de combustíveis diante das mudanças ambientais influenciado pela adoção dos carros de motores flex fuel no decorrer do período pesquisado (de 2000 a 2009). A seguir será contextualizada cada uma das estratégias competitivas introduzidas pelos autores.

\subsubsection{Estratégia de oportunidades}

De acordo com Zaccarelli e Fischmann (1994) esta estratégia está voltada para atender eventuais oportunidades que acontecem por um determinado período de tempo. 
Durante o período de gozo de uma determinada condição favorável e temporária toda a organização é completamente transformada para atender esse momento e fora dele busca-se operar em no menor nível possível de atividade.

Aaker (2007) acredita que o foco da estratégia de oportunidades está baseado no presente e os indicadores de qualidade são medidos pela flexibilidade e a capacidade da organização em responder rapidamente às oportunidades à medida que elas surgem. $\mathrm{O}$ autor ainda infere que "a organização é adaptável, com capacidade de ajustar seus sistemas, estrutura, pessoas e cultura para acomodar novos empreendimentos. A estratégia de oportunidade é dinâmica, e mudança é a norma.” (Aaker, 2007. p.162)

Outra característica apontada pelo autor é o ciclo imposto de mudanças. Ou seja, novos produtos são explorados e lançados e outros recebem menos ênfase ou até mesmo são descontinuados; novos mercados são explorados diante das oportunidades e vendem-se negócios e surgem outros; surgem novas sinergias e ativos são criadas durante a exploração da oportunidade; as pessoas deste tipo de organização são geralmente empreendedoras, sensíveis a oportunidades e ameaças, e por isso, tendem a reagir rapidamente.

\subsubsection{Estratégia de desinvestimento}

Zaccarelli e Fischmann (1994) afirmam que a estratégia de desinvestimento consiste em desistir de um determinado negócio ou mesmo encerrar todas as atividades da organização. Aaker (2007) acredita que quando o ambiente de uma organização e seu posicionamento é desfavorável a alternativa final seria realmente o desinvestimento ou a liquidação dos negócios. O autor atribui decisão desta estratégia aos fatores listados abaixo:

1. Índice de queda acentuado e acelerado não havendo demandas duradouras para a organização;

2. Duradouras e acentuadas das guerras de preços motivadas por uma concorrência desleal; 
3. Posicionamento da organização é fraco e um ou mais concorrentes conquistaram uma vantagem irreversível;

4. Mudança da direção estratégica;

5. Barreiras de saída são facilmente derrubadas (quando ativos especializados têm baixo valor, o governo não impõe regras ou condições para saída e o rompimento de contratos de longo prazo não condiciona um fator relevante).

6. Os recursos administrativos e financeiros deixam de ser investidos e são inteiramente consumidos;

\subsubsection{Estratégia de intento}

Prahalad e Hamel (1990) denominam a estratégia do intento como competência essencial (core competence) e fazem uma analogia do termo com a estrutura de uma árvore. O tronco e os galhos principais seriam os produtos essenciais; os galhos menores seriam as unidades de negócios; as folhas, flores e frutos seriam os produtos finais; e as raízes que provêm à nutrição, sustentação e a estabilidade da árvore seria a própria competência essencial. Os autores observam que se as organizações se concentram exclusivamente em seus produtos finais elas perdem o foco nos concorrentes; por outro lado, se deixa de enxergar a árvore como um sistema visualizará apenas as folhas e as conseqüências desse processo é uma organização fadada ao insucesso.

Prahalad e Hamel (1990) acrescentam ainda que as competências essenciais podem ser definidas como o aprendizado coletivo da organização em coordenar diversas habilidades de produção de forma à integrar múltiplas correntes tecnológicas. Porém a competência essencial não é somente harmonização das correntes de tecnologia, está também associada à organização do trabalho e à entrega de valor. O melhor é que ela se desenvolve à medida que é compartilhada e aplicada se tornando uma aliança que liga os negócios existentes entre si. 
Os autores descrevem também três características fundamentais para as competências essenciais: prover o acesso potencial a uma ampla variedade de mercados (1), ser uma contribuição significativa para os benefícios percebidos dos clientes no produto final (2) e ser difícil de imitar pelos concorrentes (3).

\subsubsection{Estratégia de adaptação}

A estratégia de adaptação tem grande consonância com a teoria do modelo Delta que tem por objetivo central introduzir um processo adaptativo com a capacidade continuada para responder as incertezas do ambiente. A teoria desenvolvida por Hax e Wilde (1999) está centrada em três opções estratégicas: melhor produto (1), solução total para o cliente (2) e aprisionamento do sistema (System Lock-in) (3). A estratégia do melhor produto está baseada em produtos padronizados e busca pela participação de mercado seja através da diferenciação ou baixo custo; a solução total para o cliente está focada em customizar produtos e serviço às necessidades específica do cliente. E o aprisionamento do sistema está baseado na arquitetura aberta e o foco está em estabelecer padrões.

Hax e Wilde (1999) afirmam que na estratégia de melhor produto a prioridade é a rápida introdução de produtos, ser o primeiro no mercado e se tornar dominante no mercado em uma das duas opções estratégicas. Afirma também que as organizações podem conquistar a liderança em baixo custo buscando agressivamente alcançar economias de escala e, por outro lado, desenvolver atributos em produtos e serviços que adicionem valor percebido para o consumidor, e daí cobrar mais caro por isso. Aqui se configura relação direta com a proposta de Porter (2004) em que o autor prega a liderança em custo ou diferenciação como oportunidade de construir uma vantagem competitiva frente aos demais concorrentes. Por outro lado, Quadros Jr.(2005) salienta que as limitações da estratégia do melhor produto estão condicionadas a gerar pouca ligação com o cliente como também a convergência de posições. 
No que tange a estratégia de solução para o cliente, Hax e Wilde (1999), acredita que a medida mais importante a ser monitorada nesta estratégia é a participação de mercado (market share). Aqui o foco é oferecer um amplo e variado pacote de opções em produtos e/ou serviços, e estes deverão ser customizados para atender as necessidades específicas de um determinado cliente alvo. Quanto mais próximo a organização trabalhar do seu cliente mais capaz ela será de se antecipar às necessidades deste último. $\mathrm{O}$ autor salienta também que nesta estratégia é comumente presenciado o desenvolvimento de parceria e alianças que poderia incluir outros fornecedores e até mesmo competidores.

Para Quadros Jr.(2005) a estratégia de solução para clientes não está concentrada na cadeia interna de valor, como no posicionamento de melhor produto, mas sim no desenvolvimento de uma cadeia de valor integrada com fornecedores e clientes.

Por fim, a estratégia de aprisionamento do sistema ou System Lock-in é o posicionamento mais abrangente de todas as opções anteriores, pois não foca estritamente no produto ou cliente, mas sim toda a cadeia - da produção à distribuição, fornecedores, competidores, complementadores e clientes. E, neste caso específico, o foco está no que os autores denominam complementadores. Quadros Jr.(2005, p. 28) define complementadores como "uma empresa que fornece produtos e serviços que adicionam valor aos produtos e serviços da própria empresa". A grande diferença deste posicionamento com as duas anteriores é a possibilidade em desenvolver mecanismos que ditarão o padrão do setor.

Quadros Jr.(2005) faz lembrar que existem duas condições necessárias para o aprisionamento do sistema se torne viável. A primeira condição é o aumento do valor do produto ou serviço aumentar com o número de usuários, permitindo assim, a existência de retornos marginais crescentes; e a segunda condição é a atratividade do produto ou serviço que não está condicionada as suas características básicas, mas sim nos investimentos realizados por outros agentes externos à organização, muitas vezes realizados pelos complementadores. 


\subsubsection{Estratégia de diferenciação de produto-mercado}

Poderia ser descrita como a busca pela diferenciação através da segmentação de mercados ou produtos. Zaccarelli e Fischmann (1994) atribuem duas ações inerentes a esta estratégia - conquistar uma diferenciação produto-mercado em relação ao concorrente (1) e proteção contra a entrada de outra empresa no mesmo nicho de mercado (2).

Ansoff (1990) relata que esta estratégia competitiva surgiu ao passo em que a teoria microeconômica $^{20}$ não era mais capaz de assegurar o sucesso obtido durante muitos anos pelas organizações, fator este, motivado especialmente pela mudança do comportamento dos clientes e compradores que passaram a exigir uma maior variedade de produtos e/ou serviços $(\mathrm{P} / \mathrm{S})$ que pudessem atender suas demandas mais específicas ou até mesmo a necessidade de demonstrar status social. Além disso, o autor relata que as organizações também passaram a perceber que a imagem dos seus $\mathrm{P} / \mathrm{S}$ influenciava muito mais os compradores e clientes do que a sua própria funcionalidade em si. E esse processo poderia ser fortemente influenciado por propagandas maciças ou promoções.

Neste sentido, as organizações descobrem a possibilidade de aglomerar os gostos e preferências dos seus clientes, assim como criar ou influenciar novos gostos e preferências. Daí, a diferenciação em mercado ou em produto torna-se uma importante estratégia competitiva, afirma Ansoff (1990).

O autor define a estratégia de diferenciação de mercado como a criação de nichos de mercado pelo qual a organização cria uma imagem distinta para os clientes potenciais a respeito dos seus $\mathrm{P} / \mathrm{S}$; esse processo envolve também a decisão pela participação relativa de mercado que poderia ser caracterizado pela participação dominante, competitiva ou secundária. Em relação a estratégia de diferenciação de $\mathrm{P} / \mathrm{S}$ poderia ser descrita como a criação de nichos de produtos que diferenciam o desempenho dos $\mathrm{P} / \mathrm{S}$ da organização dos que são ofertados pelos concorrentes através da pratica estratégia

\footnotetext{
${ }^{20}$ Conquista de uma economia de escala através do aumento do volume de vendas permitiria a organização obter os menores custos unitários e maior participação dominante de mercado.
} 
micro-econômica (menor custo e produtos não diferenciados), da inovação, ou da imitação.

\subsubsection{Estratégia de diferenciação funcional}

A estratégia de diferenciação funcional busca melhorias pontuais na eficiência ou eficácia dos processos internos da organização como, por exemplo, maior rapidez, menor tempo de espera, maior qualidade, custo baixo, etc. Para Zaccarelli e Fischmann (1994. p. 18) afirmam que "quanto maior for o tempo para algum competidor eliminar a diferenciação funcional, mais duradoura será a vantagem competitiva conquistada por essa estratégia." Os autores também observaram três ações inerentes a essa estratégia que seria: (1) necessidade de conhecer o sistema produtivo (do chão de fábrica ao organograma da área industrial); (2) envolvimento dos empregados durante a implementação e (3) monitoramento constante do ambiente.

Wheelwright e Hayes (1985) ${ }^{21}$ acreditam que o segredo para ter sucesso nesta estratégia é perceber que é possível competir através da fabricação e se obter vantagens competitivas, pois é a fabricação que responde pela maior parte da força de trabalho e também concentram os principais ativos.

Os autores descrevem nove tipos de escolhas em que se pode identificar o estágio competitivo de fabricação organizacional assim como também traçar metas para atingir o mais elevado nível de eficácia competitiva.

1. Capacidades: tamanho, programação ou tipo.

2. Instalações: tamanho, localização, especialização.

3. Tecnologias de Equipamentos e Processos: escala, flexibilidade, interconexão.

4. Integração vertical: direção, extensão e equilíbrio.

\footnotetext{
${ }^{21}$ IN: Montegomery e Porter (1998. p. 99-122)
} 
5. Fornecedores: número, estrutura, tipo de relacionamento.

6. Novos Produtos: entrega à fabricação, partida, modificação.

7. Recursos Humanos: seleção e treinamento, remuneração, seguridade.

8. Qualidade: definição, papel, responsabilidade.

9. Sistemas: organização, programação, controle.

Ainda neste aspecto, Wheelwright e Hayes (1985) observaram que existem quatro estágios distintos da organização no que tange a percepção da fabricação como um aliado em busca da eficácia competitiva.

- Estágio 1: é o estágio mais baixo da orientação da estratégia de fabricação. É caracterizado por baixos investimentos em pessoal, tecnologias e instalações. A alta gerência percebe a função de fabricação como incapaz de influenciar a competitividade organizacional. Grande resistência a mudanças e investimentos no setor. As decisões estratégicas nesse nível são delegadas a especialistas externos.

- Estágio 2: Característico dos setores oligopolistas, em que se têm bem definidos os concorrentes e as empresas do setor tentam manter-se no status quo. Investimentos ofensivos na fabricação estão geralmente associados a novos produtos ou necessidade de suprir aumento da demanda. Desta forma, os investimentos passam a ter um caráter defensivo ou para redução de custos. A alta gerência considera a fabricação como um processo neutro na busca da vantagem competitiva e para lidar com as decisões estratégia define a alocação de recursos como a estratégia mais eficaz.

- Estágio 3: A fabricação é percebida como um suporte interno e espera-se que dê o suporte e fortaleça a posição competitiva da organização. Os avanços tecnológicos são vistos como um processo natural da mudança estratégica ou a obtenção de um posicionamento estratégico. Os gerentes de fábrica não são envolvidos no processo de formulação estratégica, mas espera-se deles o comprometimento e a execução do planejamento. 
- Estágio 4: Espera-se que a fabricação tenha um papel de apoio à organização dando contribuições importantes para o sucesso competitivo. Estas organizações monitoram o ambiente tecnológico para prever as possíveis tendências e novas práticas de fabricação. Desenvolve melhorias contínuas nos processos e na infra-estrutura a fim de garantir o melhor aproveitamento das oportunidades. O planejamento de longo prazo considera a capacidade de produção para definição dos objetivos estratégicos. Há uma sinergia entre os setores organizacionais e a fabricação.

Wheelwright e Hayes (1985) acreditam que esses quatro estágios sugerem que tipo de foco da organização em relação à fabricação. E para atingir o estágio quatro, requer mudanças significativas em toda a organização, iniciando pelo gerenciamento dos recursos humanos. É necessário dar mais ênfase ao desenvolvimento gerencial; a força de trabalho deverá estar empenhada em obter o melhor desempenho competitivo global da organização com foco na solução dos problemas e não mais comando e controle. Essa mudança influenciará a organização a progredir através da experimentação criativa propiciando amplo aprendizado organizacional.

Os autores acreditam que as organizações somente implementam mudanças nos estágios iniciais quando pressões do ambiente externo impõem mudanças significativas e as forçam caminhar para os estágios seguintes. Para ocorrer mudanças nos estágios 1 e 2 é preciso ter esgotado as possibilidades de solucionar o problema na função de fabricação com as medidas já conhecidas. Após fracassar nelas é que as organizações buscarão novas soluções e caminhará para os estágios seguintes. Já o estágio 3, as mudanças surgem quando os gerentes passam a questionar a eficácia do pacote pronto de soluções adotado. Ou ainda, quando concorrentes ameaçam diretamente a estabilidade da organização. Pode também, a organização perceber previamente uma vantagem competitiva se transitar para o estágio 3. A transição para o nível 4 requer um esforço muito maior do que os anteriores tanto em qualidade quanto em intensidade, pois envolverá uma mudança significativa como a organização enxerga a fabricação - deixando de ser insignificante para ter igual relevância dos demais setores organizacionais em busca da vantagem competitiva. 
Os autores concluem que é o estágio quatro que oferece maior potencialidade de se conquistar uma vantagem competitiva mais duradoura, pois há uma integração mais estreita entre os projetos e a capacidade de processos, o que propicia uma maior flexibilidade de fabricação; entregas mais rápida surgem através do encurtamento do ciclo de produção dos produtos e os custos mais baixos surgem através das melhorias contínuas na qualidade e na confiabilidade dos produtos. Ao contrário do que ocorre tradicionalmente em que se busca para melhorar o desempenho - proporcionar flexibilidade pelo excesso da capacidade; entregas mais rápida através do aumento do estoque de produtos acabados; redução dos custos pelo aumento da produtividade da mão-de-obra.

\subsubsection{Estratégia de inovação.}

É importante lembrar que foi Schumpeter, como descreve Figueiredo (2009), o primeiro autor a introduzir uma concepção mais amplia do conceito de inovação. E sendo assim, inovação é para o autor muito além de novos produtos e novos processos é também novas formas de gestão, novos métodos de produção, abertura de novos mercados e criação de novas fontes provedoras de matéria-prima e insumos. E, neste sentido, a "inovação implica unir diferentes tipos e partes de conhecimento e transformá-los em novos produtos e serviços úteis para o mercado ou para sociedade" Figueiredo (2009, p.31)

Ansoff (1968) acredita que a inovação passou a ser importante durante o período do pós-guerra mundial, em que, trouxe consigo uma mudança no padrão estratégico das organizações. Três principais mudanças desse período podem ser resumidas como: (1) aumento da taxa de substituição de produtos através de melhorias contínuas objetivando manter e estimular a demanda saturada em algumas áreas; (2) redução drástica do ciclo de vida de muitos produtos impactados pela introdução de novas tecnologias; (3) aumento de recursos para criar novas demandas influenciando o consumidor a ter novas atitudes e desejos. 
Para Tidd et al, (2008) são os ambientes competitivos que forçam as organizações a inovarem. Compelidas com perdas significativas de margens buscam alternativas para refazer seus caixas. $\mathrm{O}$ autor afirma de forma categórica que inovações em produtos, serviços ou processos podem distanciar a concorrência e, principalmente, gerar retornos financeiros significativos. Neste mesmo pensamento Costa (2007) acredita que uma das maneiras de escapar da concorrência direta é desenvolver a habilidade de aplicar a estratégia da inovação competitiva. De acordo com o autor, isso envolve ter metas e objetivos ambiciosos; em que a organização poderá determinar, por exemplo, um percentual desejado do faturamento oriundo exclusivamente de inovações. Deve-se entender de estratégia de inovação competitiva da seguinte forma:

\footnotetext{
"o esforço e direcionamentos sistemáticos e consistentes para criar, continuamente, novas soluções, novas aplicações para os produtos existentes, novos produtos, novos clientes, novas formas de vender, de comprar os insumos, de distribuir os produtos ou serviços, de produzir, de formatar, enfim tudo aquilo que naquele mercado especifico seja entendido como novidade”. Certo (2007, p. 171)
}

Para Kotler e Armstrong (2007), as organizações devem buscar incessantemente por implementar melhorias reais em produtos e serviços. Melhorias reais visam atender melhor as expectativas do consumidor. Os autores afirmam que a implicação para as organizações que não forem capazes de promover melhorias continuadas estão fadadas a perder clientes para os concorrentes.

Por outro lado, Zaccarelli e Fischmann (1994) alertam sobre dois riscos inerentes a estratégia de inovação: (1) acreditar na viabilidade de uma inovação quando esta é inviável e (2) a inovação ser viável, mas a empresa não dispor de condições de superar eventuais resistências do ambiente no qual está inserida.

Para evitar tais cenários, Bass (2002) afirma que a estratégia de inovação deverá centrar em três proposições básicas: (1) compartilhar a competência central da organização; (2) ampliar o uso das competências centrais; (3) expandir a competência central para outros negócios, setores e até mesmos novos produtos. Quando a organização está centrada na sua competência central busca ampliar os seus horizontes de atuação e minimiza os riscos inerentes ao processo. 
Sendo assim, Costa (2007) salienta que a estratégia voltada para a inovação implica em organizações capazes de identificar as necessidades emergentes dos clientes; em ter habilidades capazes de criar novas formas de relacionamento com os clientes e o público-alvo; em aproveitar oportunidades existentes em ambientes que surgem com regulamentações ou desregulamentações, como também no processo de globalização, de internacionalização e até mesmo regionalização; além de estar pronto para aproveitar as oportunidades que surgem com as mudanças dos hábitos de consumo.

Figueiredo (2009) descreve cinco tipos e níveis da inovação existentes que por sua vez podem configurar um tipo de estratégia em inovação a ser adotada pelas organizações. A primeira se refere a inovação básica que configuram pequenas alterações com base na cópia ou imitação de tecnologias existentes. A segunda se refere a inovação incremental intermediária sendo caracterizada por pequenas melhorias em tecnologias existentes, mas por sua vez se configurem como uma novidade para a empresa. A terceira é denominada inovação incremental avançada e trata-se de uma inovação para o mercado em que a organização atua pode ser o lançamento de novos produtos, processos ou ainda sistemas, mas sem alterar a tecnologia existente. A quarta é a inovação arquitetural que envolve a mudança em elementos da tecnologia sem alterar os componentes individuais dos produtos e serviços, é considerada uma inovação para o mercado e onde a organização opera. A quinta e última é denominada inovação radical e leva este nome por ser caracterizado pela introdução de algo novo para o mundo e por isso se estabelece um novo conceito mundial.

\subsubsection{Estratégia de evolução}

Nessa estratégia, não se tem o interesse em ser o primeiro, porém busca-se pelas melhores práticas e depois implementá-las. Zaccarelli e Fischmann (1994) mencionam que a estratégia de evolução não é pró-ativa no que tange as inovações, mas considera que o ambiente está em processo constante de mudança; para medir esse processo utiliza como ferramenta o monitoramento do ambiente, cenários ou antecipações. A idéia central do monitoramento consiste em aplicar as melhores práticas do mercado; já 
a do uso de cenários ou antecipações consiste alinhar as ações da organização frente às previsões estabelecidas pelo uso das ferramentas.

O monitoramento utiliza de diferentes fontes de informação para montar o conjunto de previsões que auxiliarão as decisões do planejamento estratégico e a intenção é observar o passado e o presente para compreender as implicações do futuro. Alan Porter (1991) descreve os principais objetivos do monitoramento: detectar eventos socioeconômicos, tecnológicos e científicos que são relevantes para a organização; definir as possíveis implicações destes eventos sobre a organização assim como definir as possíveis ações a serem tomada na eventualidade da ocorrência destes eventos; buscar por oportunidades inerentes as mudanças ambientais e por fim, alerta a gerência sobre as tendências que estão convergindo, divergindo, crescendo, desacelerando e interagindo.

Schoemaker (1995) defende o uso de cenários para a construção do planejamento estratégico por acreditar que esta ferramenta habilita a organização a tomar as melhores decisões no presente e que influenciarão o futuro através da identificação das oportunidades e incertezas. Além disso, seria a ferramenta mais completa, pois permite que a organização enxergue além do óbvio, garante o autor. Isso permite os gerentes se tornarem mais confiantes e preparados para o futuro, minimizando os erros usuais do processo de decisão. A construção de cenários envolve uma série de etapas que vai desde a decisão do escopo da análise (produtos, mercados, tecnologias), identificação dos principais stakeholders e identificação de tendências e incertezas. Geralmente, se faz o uso da opinião de especialistas ou mesmo programas desenvolvidos especificamente para construção de cenários como o Delphi, por exemplo. O contexto geral é olhar para o futuro e prever situações que poderão gerar implicações para a organização de alguma maneira. 


\subsubsection{Estratégia de reação}

Zaccarelli e Fischmann (1994. p. 19) define como "uma decisão prévia de agir em função do que os competidores fazem ou têm intenção de fazer". Porter (1989) denomina esse processo de estratégia defensiva e tem dois objetivos principais: (1) evitar que concorrente dê início a um movimento; (2) reação aos movimentos dos competidores ao passo que eles vão ocorrendo.

Já Brown e Eisenhardt (1998) mencionam que a estratégia de reação está baseada em responder a ação de um competidor com produtos e/ou serviços melhores ou ainda oferecer uma proposta de valor superior. A estratégia da reação não implica em criar novas oportunidades, mas é claramente uma forma de resposta e gerenciamento das mudanças. Torna-se, portanto uma tática defensiva.

As autoras afirmam que para cada ação deverá haver uma estratégia definida. Quando o competidor lançar um novo produto, a organização deverá relançar um produto ainda melhor; quando surgirem novas políticas governamentais, a organização deverá criar serviços que extrapolem as mudanças impostas; quando surgir demandas inesperadas do cliente, a organização deverá repaginar os produtos existentes.

\subsubsection{Estratégia de despistamento}

As organizações buscam manter em sigilo suas ações usando de todas as ferramentas possíveis para assegurar a integridade estratégica. Gonçalves et al (2006) define a estratégia do despistamento como a estratégia invisível e consiste esconder uma determinada estratégia pelo tempo necessário para o sucesso das ações da organização. O autor salienta, porém que nenhuma estratégia é passível de ser escondida ou despistada eternamente. 
Zaccarelli e Fischmann (1994) mencionam que as ferramentas dessa estratégia é a contra-espionagem, ação sigilosa e o bluff (dar indicações de ações que serão contrárias ao serem executadas futuramente pela organização). Neste mesmo sentido, Porter (2004) menciona também que as organizações muitas vezes anunciam seus dados com objetivo de comunicar aos competidores e possivelmente influenciar o comportamento deles a favor da organização obviamente. Porém, salienta o autor que "se a empresa ("o competidor enganado") ${ }^{22}$ tiver conhecimento ou deduzir essas práticas enganadoras, elas conterão importantes sinais sobre os objetivos do concorrente e sobre as suas verdadeiras potencialidades competitivas. (Porter, 2004, p.83)

Gonçalves et al (2006) destaca que entre as ferramentas para viabilizar a estratégia do despistamento também que é possível estabelecer filtros nos relacionamentos com os dirigentes das organizações, com concorrentes, com fornecedores, comunicação de marketing ao consumidor e por fim com os recursos humanos. As principais técnicas são estabelecer contratos sigilosos com penalidades para os executivos, fornecedores e parceiros; analisar o conteúdo da fala dos executivos e ter maior atenção aos anúncios e propagandas da organização para não dar indicações que poderão ser valiosas para os concorrentes.

\subsubsection{Estratégia de cooperação}

Ajuda mútua entre organizações concorrentes e nem sempre existe uma preocupação com os resultados financeiros. Zaccarelli e Fischmann (1994) afirmam que a estratégia de cooperação está associada à terceirização e a formação de clusters.

Costa (2007) acredita que a competição e cooperação são dois vetores que movimentam as pessoas, empresas, organizações e países. E a cooperação decorreu do processo em que as organizações, diante de um ambiente cada vez mais competitivo, constataram a impossibilidade de gerenciar toda a cadeia (montante a jusante), estratégia muito

${ }^{22}$ Observação da autora. 
comum da década de 1930, como afirma o autor. Visando focar energia em suas competências centrais as organizações foram conduzidas a terceirizar algumas atividades para outras organizações que tivessem estas atividades como cerne de sua competência central. E esse processo motivou o surgimento de parceiras e alianças entre organizações e mesmos concorrentes.

As alianças entre as organizações devem proporcionar benefícios para os dois lados. Neste pensamento Lewis (1992, p.20) afirma que:

Se as ligações mais próximas com outras organizações contribuem para reduzir os riscos da empresa, inibir os movimentos dos concorrentes ou para produzir uma significante vantagem competitiva - em termos de oportunidades, custos, serviços, qualidade, novos desenvolvimentos, maior crescimento, melhor compreensão do mercado de uma organização mais ágil, e assim por diante, então as alianças são indicadas.

No que tange a formação de clusters Di Serio (2007. p.8) os define como um “mecanismo de coordenação alternativo, já que a proximidade geográfica e as repetidas trocas entre as empresas favorecem a melhor coordenação das transações e a criação de reputação". O poder da cooperação entre os clusters, segundo o autor, vai além do compartilhamento da visão sobre o mundo, mas também recursos. Favorece também parcerias e alianças como forma de aumentar as vendas e lucros. A decisão por trás de uma organização em atuar dentro de um cluster pode ser explicada pelo acesso a empregados e fornecedores mais capacitados, as informações especializadas, a bens públicos e a complementaridades com as atividades de outras organizações.

Em outra tangente de cooperação entre concorrentes é destacado por Porter (1989) como o auxílio mútuo para o desenvolvimento do mercado. Entre as opções estão o compartilhamento de custos para o desenvolvimento de mercado para novos produtos ou tecnologias; ajudar a padronizar ou legitimar uma tecnologia emergente e promover a imagem da indústria. 


\subsubsection{Estratégia de agressão}

A estratégia de agressão tem idéia contrária a estratégia de cooperação está fortemente associada a ações ilícitas com a intenção clara de prejudicar o concorrente. Se tratando de ilicitudes é muito difícil mensurar essa situação diante a possibilidade de processos jurídicos e de possíveis perdas de imagem da organização agressora. Zaccarelli e Fischmann (1994, p. 20) afirmam que "a estratégia de agressão usa formas ilícitas para prejudicar os competidores ou para beneficiar-se, mas, evidentemente, a empresa agressora não aparece como autora da agressão.” Guimarães (2000) menciona que entre os atos ilícitos estão a sabotagem e a espionagem Industrial. Deve-se incluir também a manipulação indireta dos veículos de comunicação.

Zaccarelli e Fischmann (1994, p. 20) por fim, concluíram que "evidentemente tal estratégia não é tratada nos livros, mas poucos executivos têm dúvidas da sua existência".

\subsubsection{Estratégia autoproteção}

Zaccarelli e Fischmann (1994) caracterizam esta estratégia como a busca de protetores para toda a indústria externas às organizações que compõem essa indústria. Os autores salientam que geralmente o governo tende a ser o preferido dessas organizações para validar a estratégia de autoproteção; isso pode ocorrer através de lobbies que por certo poderão influenciar a regulação ou não regulação do mercado. Além do governo, é comumente utilizado associações, sindicatos ou organizações não-governamentais. 


\subsection{Adoção tecnológica do carro flex fuel}

Vale salientar que, este subcapítulo visa uma breve discussão sobre os fatores que contribuíram para o sucesso da adoção dos carros de motor flex fuel no Brasil. Não se pretende analisar as teorias vigentes que buscam compreender o processo de decisão de adoção tecnológica nem mesmo detalhar o comportamento dos indivíduos durante o processo de adoção ou não de uma nova tecnologia.

Figueiredo (2009) destaca três níveis em que o indivíduo decide pela a adoção ou não da tecnologia. O primeiro estágio, envolve a descoberta da tecnologia; o segundo estágio, envolve a busca de conhecimento sobre a tecnologia através dos meios de comunicação e o último estágio, se caracteriza pela postura favorável, ou não, do indivíduo frente a nova tecnologia.

Bernardini Jr. (2008) menciona que a adoção de uma tecnologia pode ser afetada pelos preconceitos idealizados e concebidos pelo indivíduo e isso poderá implicar em diferentes atitudes perante uma nova tecnologia. O autor menciona a teoria da prontidão que tem o interesse em investigar as atitudes dos indivíduos com relação a uma nova tecnologia. Neste sentido, a prontidão tecnológica está resumida em dois aspectos a ser considerados os: fatores contribuidores (1) e os fatores inibidores (2). As variáveis dos fatores contribuidores são resumidas pelo otimismo que significa ter uma visão positiva da tecnologia antes mesmo de adotá-la e a inovatividade se refere à sensação que poderá permitir ao indivíduo o pioneirismo na adoção da tecnologia. As variáveis dos fatores inibidores estão relacionadas com o desconforto que é a demonstração de inabilidade com a nova tecnologia, a insegurança que é a demonstração de ceticismo, pois desconfiam sobre os atributos e as funcionalidades da nova tecnologia.

É relevante mencionar que no tange aos carros de motores flex fuel o otimismo que poderá imbuir; a questão financeira também, uma vez que a adoção da tecnologia permitiu ao indivíduo escolher o uso de combustível que melhor lhe convém. O etanol em grande parte do país se demonstra mais barato que a gasolina mesmo considerando o poder calorífico de cada produto, visto que com a gasolina é possível rodar mais 
quilômetros com um litro do combustível em relação ao etanol. Para que essa conta seja benéfica para o consumidor o etanol, em linhas gerais, precisa custar $70 \%$ menos do preço da gasolina.

Como se pode observar através do gráfico 4 , durante o período apontado pelo gráfico 4 a média geral do Brasil permaneceu abaixo dos 70\%, favorecendo positivamente as vendas do etanol, consequentemente, houve redução das despesas dos motoristas com esse tipo de combustível. Vale lembrar que os dados abaixo são uma média geral Brasil e há período, especialmente, durante a entressafra da cana-de-açúcar que essa relação não se mantém.

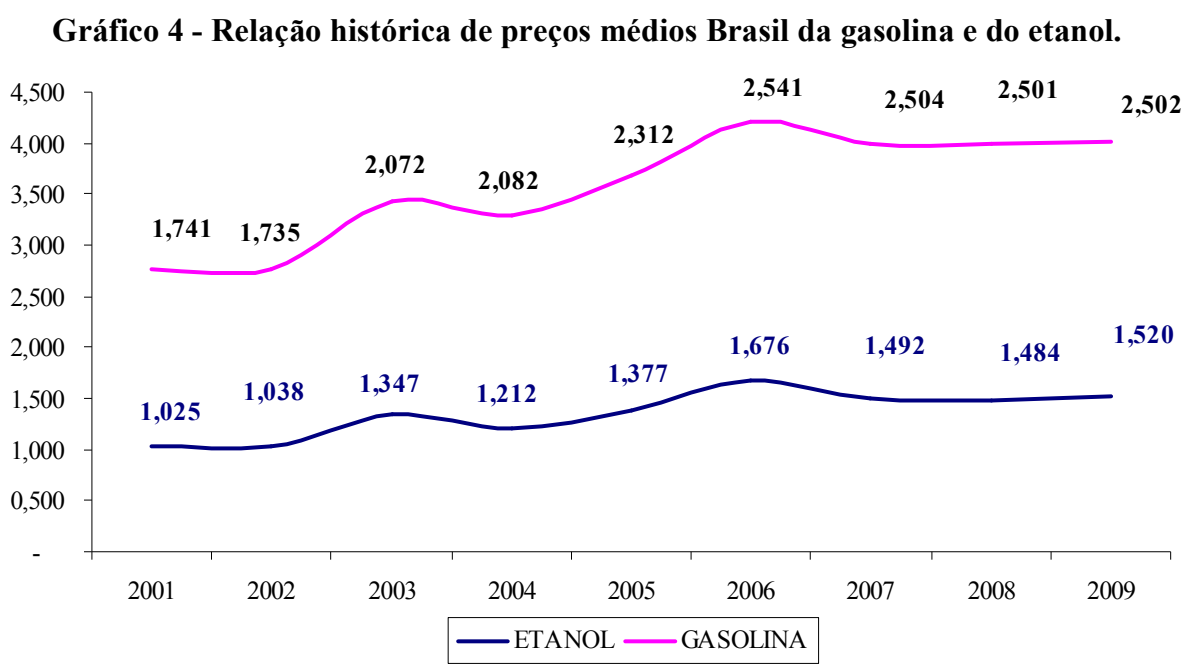

Fonte: ANP

Inovatividade seria caracterizado pelos primeiros compradores. Os desconfortos e as possíveis inseguranças poderiam ser reforçadas por experiências anteriores com o carro movido, exclusivamente, a etanol que apresentou durante esses diversos problemas de funcionalidade, além disso, a experiência de décadas anteriores poderia reforçar algum outro sentimento quanto ao etanol e o próprio carro de motores flex fuel.

Neste pensamento, Silva e Fischetti (2008) acreditam que quaisquer insatisfação com o carro movido exclusivamente a etanol e a falta do produto na hora do abastecimento na 
década de 1980, o consumidor tem o poder de trocar para o combustível que lhe convier na hora de abastecer, no entanto essas questões foram eliminadas com o desenvolvimento dos motores flex fuel.

Para Hira e Oliveira (2009) o fator relevante para o sucesso dos carros flex fuel no país se deve, entre outros fatores, principalmente, a intervenção política e governamental para o desenvolvimento da tecnologia através do total suporte dado as indústrias do setor durante todas as fases de crise, investimentos em infra-estrutura e outros investimentos de longo prazo no que permitiram o financiamento de diversos níveis para implementar melhorias que promovessem a eficiência em toda a cadeia produtiva do etanol. Como também a retirada de cena do governo quando as indústrias estavam perfeitamente prontas para liderar o salto tecnológico que seria promovido pelos carros flex fuel.

Hannan e McDowell (1990) afirmam que muitas vezes são as sistemáticas mudanças do mercado que favorecem a adoção tecnológica. Diante da visão destes autores é possível concluir que não se pode atribuir a uma exclusiva variável para o sucesso da adoção dos carros flex fuel. Há sim uma enormidade de fatores que podem ser relacionados e correlacionados, entre as mais importantes pode-se citar a atuação do governo com políticas públicas direcionadas; as melhorias no campo que promoveram eficiência da lavoura e permitiram o aumento da produção do etanol; os avanços tecnológicos na indústria automobilística nos últimos anos pode se considerar inquestionável e visivelmente acompanhada pelos motoristas; e, o fato da tecnologia flex fuel livrar o consumidor da dependência de um único combustível e agregado a isso ainda obter beneficio financeiro, sem sombra de dúvida, são fatores condicionantes à adoção da tecnologia. Não se pode esquecer também que o etanol permite aos motoristas mais engajados com a responsabilidade social e mais sensíveis às questões ambientais a adotarem um combustível menos poluente que os fósseis porque não agridem ao meioambiente. 


\subsection{Sustentabilidade e responsabilidade social}

"Há um novo requisito que exige ajustes em ultrapassadas concepções do desenvolvimento: a sustentabilidade ambiental do crescimento e da melhoria da qualidade de vida. Trata-se de um imperativo global que chegou para ficar, em virtude da percepção de que a biosfera, em níveis global, regional, nacional e local, está sendo submetida a pressões insuportáveis e prejudiciais para o próprio desenvolvimento e as condições de vida"

(Veiga, 2008. p.187)

Veiga (2008) acredita que a sustentabilidade exige do homem atual compreender as relações das diversas áreas do conhecimento para que seja possível oferecer alternativas aos problemas inerentes a relação do homem com a natureza, com o crescimento e desenvolvimento das cidades e as implicações para a biosfera. $\mathrm{O}$ autor menciona também que o tema é discutido desde a década de 1970 e, desde então, vários artigos e estudos vem tentando conceituar a sustentabilidade. Ainda não há um consenso entre os especialistas e tão pouco uma corrente predominante. Veiga (2008) afirma, porém, que a sustentabilidade nada mais é do que a necessidade em que o homem e toda sociedade estão sendo motivados a repensar na sua relação com o próprio ambiente, visando assegurar a própria existência. O homem busca ser mais responsável em suas ações, passa a conhecer e a adotar uma postura para eliminar, ou minimizar os efeitos e as possíveis conseqüências no ambiente.

Para Francisco Almeida (2010) os princípios da sustentabilidade estão baseados em três pilares: (1) econômico (2) ambiental e (3) social. O autor acredita inclusive que esses princípios não poderão estar mais desassociados das atividades empresariais e devem permear todas as decisões corporativas. Faz lembrar também que sustentabilidade está fortemente associada com responsabilidade social que poderia ser descrita como a decisão voluntária empresarial em atuar com ética em todos os negócios e agentes envolvidos durante toda a cadeia produtiva (exemplo: clientes, fornecedores, funcionários, colaboradores, governo etc.) assim como buscar integrar ações para promover uma sociedade mais justa e um meio ambiente mais limpo. 
Neste sentindo Aligleri et al (2009, p.9) acreditam que a sustentabilidade deve permear a responsabilidade social. Os autores introduzem o modelo de Zadek em que demonstra os cinco estágios dos quais permeiam as decisões da organização sobre a responsabilidade social. O primeiro estágio, denominado defensivo, tange a negação da organização de qualquer responsabilidade social (práticas, responsabilidades, impacto e conseqüências das atividades). O segundo estágio, denominado conformidade, é considerado o mais baixo nível de envolvimento organizacional no que tange a responsabilidade social, ou seja, executa estritamente o necessário para assegurar a não erosão do valor econômico corporativo. O terceiro estágio, denominado gerencial, passa a ser o envolvimento dos aspectos sociais nos processos gerencias cotidianos. $\mathrm{O}$ quarto estágio, denominado estratégico, verifica-se a integração da abordagem no escopo estratégico dos negócios e essas ações visam reforçar o valor econômico ao longo prazo e poderá ainda representar alguma vantagem competitiva para as organizações. E, por fim, o quinto e último estágio, denominado civil, é o engajamento organizacional na ampla promoção da participação do setor na responsabilidade empresarial.

Os autores enfatizam também que a responsabilidade social é ter organizações cientes de que suas decisões, ações e atividades impactam muito mais dos que apenas os stakeholders, na visão tradicional, e sendo assim estas organizações devem ter o compromisso de responder às demandas de todos os possíveis agentes afetados. E assim concluem que:

O desempenho social inadequado e a falta de políticas bem elaboradas de cunho social e ambiental podem ter sérias implicações organizacionais, acarretando em prejuízos materiais e morais de modo a aumentar os custos e perder oportunidades de mercado. Não há como ignorar o novo compromisso das empresas, pois a questão não é parte apenas de uma sensibilização ética, mas, principalmente, econômica e mercadológica.

Aligleri et al (2009, p.9)

O anuário do Sindicom de 2004 relaciona diversos eventos promovidos pelos distribuidores de combustíveis associados ao órgão no que tange a promoção de iniciativas destinadas à promoção social, cultural, educação, esporte e de proteção ao meio ambiente. Entre eles destaca o envolvimento ou patrocínio dos distribuidores na alfabetização solidária, projetos desenvolvidos para preservação de parques e rios, 
educação no trânsito, incentivo e patrocínio aos esportes para crianças e adolescentes, programas de capacitação de jovens ao mercado de trabalho, promoção de concertos de música clássica e erudita, cinema e dança à preços populares, como também, apoio a reciclagem de embalagens, pilhas e baterias. Para o Sindicom (2004) o compromisso social dos distribuidores de combustíveis é uma realidade antes mesmo de se tornar uma obrigação.

Aligleri (2011.p.55) acredita que "no atual contexto, a gestão empresarial que responde apenas aos interesses dos acionistas revela-se insuficiente". Afirma ainda a autora que é crescente a busca por novos modelos de gestão que sejam capazes de atender às expectativas da sociedade no que tange as questões éticas, sociais e ambientais possibilita estas organizações a competir em ambientes cada vez mais hostis e que demandam por menores custos e alto padrão de qualidade.

Mas deve-se lembrar que o tema sustentabilidade é relativamente recente no âmbito empresarial e ainda mais para o setor de combustíveis. No Brasil, o tema ganha força prática com a instituição do Conselho Nacional de Meio Ambiente (CONAMA) na década de 1980 que passa a ser responsável, entre outras atribuições, desenvolver diretrizes e normas técnicas, critérios e padrões que visem à proteção ambiental e o uso sustentável dos recursos ambientais. Francisco Almeida (2010) salienta que as decisões do poder público sobre as questões ambientais objetivam regular o uso, conservação ou ainda a preservação dos recursos naturais em prol da sociedade. Quando se analisa as resoluções ou decretos criados pelo órgão ao longo dos anos se observa que as decisões estão realmente baseadas neste tripé.

E, neste contexto, a resolução n.273/2000 criou diretrizes para prevenção de acidentes ambientais e controle da poluição nos postos de combustíveis. Os principais pontos observados pelo CONAMA foi a possibilidade de contaminação do solo, água e do ar por derivados de petróleo; risco de incêndios e explosões motivados por vazamentos; aumento do número de contaminações ambientais assim como a ineficácia de resposta em casos de acidentes. As principais medidas adotadas pelo órgão foram:

- Passou a determinar diretrizes para construção, modificação, instalação, ampliação e a localização dos postos de combustíveis. 
Para qualquer uma dessas atividades passou a ser obrigatório se obter previamente o licenciamento ambiental em três estágios: (1) Licença Prévia (LP) que atesta a viabilidade ambiental; (2) Licença de Instalação (LI) que autoriza a instalação dos equipamentos necessários para operação conforme o plano aprovado anteriormente na LP; (3) Licença de Operação (LO): que autoriza a operação quando cumprido as exigências preliminares.

- Em caso de acidentes e vazamentos que representem riscos para as pessoas e para o meio ambiente serão responsabilizados os proprietários, arrendatários ou responsáveis pelo estabelecimento causador dos danos ambientais. Os distribuidores de combustíveis que abastece o posto de combustível passam a ser responsável solidário.

- Criaram diretrizes para ações a serem prestadas pelos revendedores de combustíveis nos casos de acidentes e vazamentos.

- Determinou a instalação de equipamentos para prevenção e detecção de vazamentos.

- Os postos de combustíveis passam a ser obrigados a manter os equipamentos de controle de vazamento em pleno funcionamento e prestar a manutenção adequada. Assim como ter pessoas bem treinadas para execução do plano de emergência quando necessário

Dalmonech et al (2005) estimam que adequação à nova legislação ambiental tenha resultado em um de dispêndio financeiro na ordem de $\mathrm{R} \$ 150$ a $\mathrm{R} \$ 250$ mil entre obras e aquisição de equipamentos. Os postos seguem um cronograma de adequação mínima (ex: adequação do piso da pista de abastecimento e implementação de itens de segurança contra vazamentos) ou até mesmo adequação máxima (troca de bombas e tanques). Esses eventos são coordenados pelos estados através das agências responsáveis pelo controle, fiscalização, acompanhamento das atividades geradoras de poluição.

Os custos para atender a nova legislação dependem do contrato estabelecido entre o revendedor e o distribuidor de combustíveis. Os custos podem ser integralmente arcados pelo distribuidor de combustíveis, integralmente pelo revendedor ou ainda ser 
partilhado entre esses dois agentes. O mais importante é o cumprimento dos prazos e exigências estabelecidas caso contrário os agentes estão passíveis a penalidades que podem variar de pesadas multas como também responder criminalmente por danos ao meio ambiente.

Dalmonech et al (2005) afirmam o CONOMA visando assegurar a recuperação do dano ambiental, mesmo os distribuidores de combustíveis apresentando contratos em que se eximiam de qualquer responsabilidade ambiental nas atividades desempenhada pelos postos de combustíveis, foram obrigados a responder solidariamente no caso, assumindo parte ou integralmente os custos para adequação ou reparação ambiental e isto tem motivando muitos distribuidores a mudarem seus contratos com os postos de combustíveis. Os autores afirmam também que essa nova realidade motivou aos distribuidores a reverem os contratos firmados com os postos de combustíveis.

Não há dúvida que esse será um tema que ganhará cada vez mais espaço e notoriedade. Certamente, as empresas serão obrigadas a atuar em áreas das quais não eram responsabilizadas anteriormente como o descarte correto de resíduos; o menor uso de embalagens nos produtos; incentivar a reciclagem; obter insumos de empresas também socialmente responsáveis. Para os distribuidores de combustíveis implicaria, por exemplo, a não comercialização do etanol de usinas que compram a cana-de-açúcar ou insumos em fazendas que tenha trabalho escravo e/ou infantil; serem responsáveis pelo descarte correto das embalagens de lubrificantes; incentivar e oferecer treinamento aos revendedores de combustíveis para conscientização ambiental. Além disso, acredita-se que a tendência é um governo mais atuante e uma sociedade mais consciente e sensível aos aspectos ambientais. A sustentabilidade é, sem dúvida, um tema essencial e que deve ser incorporada a estratégia das organizações. 


\section{DESCRIÇÃO DA PESQUISA}

\subsection{Metodologia de pesquisa}

Esta é um pesquisa qualitativa, como descreve Sampieri et al (2006, p.11) "é um estudo que busca compreender seu fenômeno de estudo em seu ambiente usual”. O autor salienta que os estudos qualitativos não pretendem estabelecer generalizações para as populações, nem mesmo obter amostras representativas, como também não pretendem que os estudos sejam replicados. E, por essas razões, são geralmente fundamentados em um processo indutivo que significa ir de um contexto particular para o geral. A idéia central do processo indutivo é explorar, descrever e gerar perspectivas teóricas.

Esta pesquisa assumiu caráter exploratório. Conforme Gil (2008, p.27) “as pesquisas exploratórias são desenvolvidas com o objetivo de proporcionar visão geral, de tipo aproximativo, acerca de um determinado fato." São desenvolvidas, especialmente, quando o tema ainda pouco explorado ou quando pesquisador necessita de mais infomações para fomulação de idéias e conceitos.

Foi utilizado como roteiro de pesquisa sugerido por Hair et al (2005). Segundo os autores, uma pesquisa exploratória pode assumir várias formas, mas recomenda uma completa revisão na literatura para melhor compreensão de uma questão. A revisão da literatura deverá incluir períodicos acadêmicos e comerciais, livros, e outras fontes em que o tema seja tratado.

Como segunda etapa, deve-se escolher uma técnica de entrevista exploratória. E entre as opções dadas pelo autor foi escolhido a aplicação de entrevistas semi-estrituradas. De acordo com Hair et al (2005, p. 163) essa técnica "resulta no surgimento de informações inesperadas e esclarecedoras, melhorando as descobertas" Antes de seguir na segunda etapa o autor recomenda que o pesquisador tente se ambientar com a linguagem das empresas a serem pesquisada, pois poderá facilitar a compreensão dos resultados. Para isso, recomenda conversas informais com pessoas ligadas ao setor, ou 
das empresas a serem pesquisadas. Ou ainda, quando possível ter acesso aos arquivos das empresas pesquisadas.

Godói et al (2006,p. 304) sugerem para esses casos a aplicação de entrevistas conversacional livre. Segundo os autores esse tipo de entrevista é caracterizado "pelo surgimento das perguntas nos contextos e nos cursos naturais à interação.” Sendo assim são conversas livres e sem nenhum roteiro previamente estabelecido.

Para analisar os dados seguiu-se o roteiro sugerido por Sampieri et al (2006) na preparação da revisão das entrevistas, na preparação do material para análise, eliminando as informações desnecessárias, seleção e classificação das informações mais relevantes, podendo realizar resumos dos assuntos mais importantes, e como etapa final os autores recomendam a transcrição das informações.

\subsection{Universo da pesquisa}

De acordo com ANP (2010), em 2009 existiam 140 distribuidores de gasolina e 154 distribuidores de etanol.

\subsection{Amostra da pesquisa}

Serão pesquisadas os distribuidores BR Distribuidora, Ipiranga, Shell e Esso/Cosan. Vale salientar que esse grupo, se analisando em conjunto, representou em 2009 quase que $70 \%$ de todo o volume de vendas nacional de gasolina e aproximadamente $60 \%$ de todo o volume de vendas nacional de etanol.

De acordo com Gil (2008, p. 94) essa decisão constitui uma amostragem não probabilística por tipicidade ou intencional o que significa dizer "selecionar um 
subgrupo da população, que com base nas informações disponíveis, possa ser considerado representativo de toda a população".

\subsection{Técnicas de coleta, tratamento e análise de dados}

Seguindo o roteiro de pesquisa apresentado por Hair et al (2005) foi realizado uma extensa revisão bibliográfica utilizando-se de palavras chaves em diferentes bases de dados. Em um segundo momento, foi pesquisado informações sobre os distribuidores de combustíveis em diferentes fontes como também nos próprios sites de cada um dos distribuidores de combustíveis pesquisados.

Com o objetivo de se familiarizar com a linguagem do setor, durante os meses de janeiro/10 a julho de 2011 foram realizadas sessões de entrevistas conversacionais livres como define Godói (2006) com revendedores de combustíveis das cidades de São Paulo, Osasco, Barueri e Campinas. A escolha dessas cidades foi por conveniência da autora, especificamente em Campinas foi entrevistado um dos maiores revendedores da região que tem ampla experiência e é revendedor há mais de 20 anos, proprietário de postos de várias bandeiras, este revendedor será denominado "Revendedor A".

Essas entrevistas conversacionais livres tinham duração média de 20 a 30 minutos. Geralmente discorria sobre uma dúvida específica da autora. Foram diversos encontros pessoalmente no próprio posto de combustível ou paradas rápidas para um café ou almoço. Algumas informações julgadas relevantes foram devidamente anotadas em um caderno. Essa etapa se tornou necessária também para conhecer as mudanças no ambiente a partir da visão e percepção dos clientes dos distribuidores de combustíveis. Além de buscar compreender melhor a linguagem utilizada pelo setor.

Em um segundo momento, foi desenvolvido o roteiro das entrevistas semi-estruturadas em concordância com a fundamentação teórica. As entrevistas foram realizadas individualmente com cada um dos gerentes dos distribuidores de combustíveis nos meses de junho e julho de 2011. O tempo médio de duração das entrevistas foi de 1 
hora e 26 minutos. Todos os gerentes entrevistados foram do sexo masculino. A média de tempo de trabalho dos gerentes na empresa atual foi de 16,6 anos; o tempo médio em que ocupam os cargos de gerentes de vendas foi de 5,5 anos. Todas as informações pessoais e todos os dados que possam servir de identificação desses gerentes foram propositadamente omitidos para preservar a identidade dos entrevistados.

A Shell foi a única empresa em que foi possível entrevistar mais de um gerente. A primeira entrevista foi realizada com o primeiro gerente da Shell em 06 de junho de 2011. No dia 14 de junho de 2006 foi entrevistado o gerente da Esso/Cosan. No dia 16 de junho de 2011 foi entrevistado o segundo gerente da Shell. No dia 26 de junho foi entrevistado o gerente da Ipiranga e no dia 14 de julho de 2011 foi entrevistado o gerente da BR.

Todas as entrevistas foram gravadas em um gravador digital convencional. Como proposta de organização dos dados foi seguido o roteiro sugerido por Sampieri et al (2006). Foram realizadas as transcrições das entrevistas em Word e, posteriormente, organizadas por temas com o objetivo de facilitar a análise dos dados. 


\section{APRESENTAÇÃO E ANÁLISE DOS RESULTADOS}

Esse capítulo está organizado em quatro partes. Na primeira parte, será apresentado o histórico dos distribuidores de combustíveis objetivando contextualizar o leitor com as organizações pesquisadas.

Alguns fatos relevantes serão destacados em ordem cronológica, essas informações foram obtidas basicamente do próprio site das organizações pesquisadas e as outras informações adicionais foram obtidas nos diversos anuários do Sindicom e da Fecombustíveis.

Na segunda parte, será apresentado o resultado da pesquisa com base nas percepções que foram relatadas pelos gerentes dos distribuidores de combustíveis, em entrevistas realizadas sobre as mudanças ambientais do setor, no período de 2000 a 2009.

$\mathrm{Na}$ terceira parte, buscou-se uma compreensão sobre as estratégias competitivas seguindo o modelo proposto por Zaccarelli e Fischmann (1994) com os dados das entrevistas realizadas. Por último, foi analisado o papel da sustentabilidade das organizações com base na percepção dos gerentes dos distribuidores de combustíveis.

Com o objetivo de preservar a identidade dos entrevistados serão omitidos os nomes e quaisquer elementos que possam servir de identificação dos entrevistados. O gerente da distribuidora BR, passará a ser denominado G.BR; o gerente Ipiranga, passará ser denominado G.IPI; o primeiro gerente entrevistado da Shell será denominado Shell A e o segundo entrevistado Shell B; e, por fim, o gerente da Esso será denominado G.Esso/Cosan. 


\subsection{Apresentação dos Distribuidores de Combustíveis}

Serão apresentadas algumas informações históricas dos distribuidores de combustíveis desde o início de suas operações no Brasil e algumas outras informações relevantes sobre estas organizações. As informações de vendas de combustíveis e a quantidade de postos de combustíveis foram obtidas através da ANP. As informações sobre as lojas de conveniência foram obtidas através do anuário do Sindicom (2010).

\subsubsection{BR Distribuidora}

Em 1963 surgiu, em Brasília, o primeiro posto de combustíveis. E em 1971 a legislação em vigor criou a Petróleo Distribuidora uma subsidiária da Petrobras, nesse ano, o distribuidor contava com uma rede de 840 postos. Em 1973, adquiriu o controle da então distribuidora Petrominas, acentuando ainda mais sua liderança na participação de mercado. Em 1979, passou a ser a primeira a comercializar o etanol hidratado. Em 1993, mudou a logomarca e passa a ser chamada BR. Em 1994, inaugurou a primeira loja de conveniência com o nome "BR Mania".

Quadro 4 - Informações e dados da BR Distribuidora

\begin{tabular}{|c|c|}
\hline Slogan & Postos Petrobras: O Brasil se encontra aqui. \\
\hline *Loja de Conveniência & BR Mania \\
\hline Número de lojas & 730 \\
\hline Faturamento mensal médio (R\$) & 64,313 \\
\hline Área Média $\left(\mathrm{m}^{2}\right)$ & 64,7 \\
\hline & Gasolina de alta octanagem (Podium) \\
\hline Produtos aditivados do ciclo Otto & Gasolina Aditivada (Supra) \\
\hline Controle de Qualidade dos combustíveis & "De olho no combustível" \\
\hline **Quantidade de postos em 2009 & 6,786 \\
\hline $\begin{array}{l}\text { **Participação de vendas nacionais da gasolina } \\
\text { (2009) }\end{array}$ & $28,93 \%$ \\
\hline **Participação de vendas nacionais do etanol (2009) & $22,24 \%$ \\
\hline
\end{tabular}




\subsubsection{Ipiranga}

Em 1936, no Rio Grande do Sul foi constituída a Ipiranga S.A Cia Brasileira de Petróleo. Em 1938, surgiu na região o primeiro posto da rede. Em 1957, foi constituída a Distribuidora de Produtos de Petróleo Ipiranga. Em 1959, adquiriu os postos da Gulf Oil Corporation e fez surgir a Companhia Brasileira de Petróleo Ipiranga. Na década de 1980, a Ipiranga unificou a identidade visual dos postos de combustíveis. Em 1993, adquiriu a rede de postos da Atlantic, confirmando assim seu papel de vice-liderança na participação de mercado. Em 1997, lançou seu programa de qualidade de combustíveis. Em 2007, o Grupo Ultra, assumiu as bases de distribuição e os postos de combustíveis da Ipiranga nas regiões Sul e Sudeste, enquanto a Petrobras se tornou responsável pelas demais regiões do país. Em 2008, assumiu as operações da rede Texaco no Brasil.

Quadro 5 - Informações e dados da Ipiranga

\begin{tabular}{|c|c|}
\hline Slogan & $\begin{array}{r}\text { Postos Ipiranga: um lugar completo } \\
\text { esperando por você! }\end{array}$ \\
\hline *Loja de Conveniência & AMPM \\
\hline Número de lojas & 963 \\
\hline Faturamento mensal médio $(\mathrm{R} \$)$ & 79.958 \\
\hline Área Média $\left(\mathrm{m}^{2}\right)$ & 51,8 \\
\hline Produtos aditivados do ciclo Otto & $\begin{array}{r}\text { Gasolina de maior octanagem que a comum } \\
\text { (Original Premiun) } \\
\text { Gasolina Aditivada (Original) }\end{array}$ \\
\hline Controle de Qualidade dos combustíveis & "Programa de Controle de Qualidade" \\
\hline **Quantidade de postos em 2009 & 5.722 \\
\hline $\begin{array}{l}\text { **Participação de vendas nacionais da gasolina } \\
\text { (2009) }\end{array}$ & $20,15 \%$ \\
\hline **Participação de vendas nacionais do etanol (2009) & $17,01 \%$ \\
\hline
\end{tabular}

\subsubsection{Shell}

A Shell chegou ao Brasil em 1913, com o nome Mexican Petroleum Products Co. Shell. Em 1942 inaugurou a Filmoteca ação de apoio à cultura, em 1946 passou a ser chamada Shell-Mex Brazil Ltda e em 1947, oficializou a parceria com a Ferrari. Em 1954, lançou a gasolina com ignition control additive (I.C.A.) sigla em inglês pode ser 
traduzido como aditivo anti-detonação, que segundo o distribuidor melhoraria a eficiência do combustível no motor. Em 1957, abriu o primeiro posto de combustíveis em Brasília.

Na década de 1960, passou a ser chamada Shell Brasil, em 1971, se associou com a Petróleo Sabbá, garantindo assim presença na região Norte do país. Em 1987, inaugurou a primeira loja de conveniência do país sob a marca "Express" e em 1995, mudou para Select. A Shell decidiu sair do Centro Oeste do país. Em 2001, lançou o programa de qualidade denominado DNA. Em 2009, fechou parceria com a rede Simarelli e voltou a garantir presença no Centro-Oeste. Em 2009/2010, anunciou a formação da joint venture com a Esso-Cosan

Quadro 6 - Informações e dados da Shell

\begin{tabular}{|c|c|}
\hline Slogan & "Aproveite o máximo cada gota" \\
\hline *Loja de Conveniência & $T_{1}$ \\
\hline Número de lojas & 288 \\
\hline Faturamento mensal médio $(\mathrm{R} \$)$ & 77.716 \\
\hline Área Média (m2) & 66 \\
\hline Produtos aditivados do ciclo Otto & $\begin{array}{r}\text { Gasolina Aditivada (VPower) } \\
\text { Etanol Aditivado (VPower) }\end{array}$ \\
\hline Controle de Qualidade & "DNA" \\
\hline **Quantidade de postos em 2009 & 2.178 \\
\hline $\begin{array}{l}\text { **Participação de vendas nacionais da gasolina } \\
\text { (2009) }\end{array}$ & $11,29 \%$ \\
\hline **Participação de vendas nacionais do etanol (2009) & $13.09 \%$ \\
\hline
\end{tabular}

Fontes: **ANP, *Sindicom.

\subsubsection{Esso/Cosan}

Em 1912, se instalou no Brasil a Standard Oil Company of Brazil comercializando gasolina e querosene em tambores. Em 1921, trouxe ao país a primeira bomba de rua ${ }^{23}$ para gasolina. Em 1925, trouxe ao país o primeiro caminhão tanque para transporte e

\footnotetext{
${ }^{23}$ Nesse período, não haviam postos de combustíveis como é concebido atualmente. Antes os produtos combustíveis e derivados de petróleo eram comercializados em tambores e latas. Por este motivo a primeira bomba de combustível ficou conhecida como bomba de rua, pois, realmente, ficava instalada nas calçadas de ruas. .
} 
distribuição de combustíveis. Em 1935, produziu os primeiros anúncios publicitários através de modernas técnicas publicitárias.

Em 1941, introduziu o "Repórter Esso" que acabou se tornando um dos principais veículos de comunicação do país. Em 1959, colocou em funcionamento o primeiro posto. Na década de 60, mudou a razão social para Esso Brasileira de Petróleo. Em 1989, lançou a loja de conveniência da rede sob a marca "Stop \& Shop", posteriormente, ampliou as opções de lojas de conveniência com o surgimento do "Hungry Tiger".

Em 1993, foi a primeira a lançar o Etanol aditivado (Esso Etanol Maxxi), excluído do portfólio posteriormente. Em 1997, se tornou a primeira a lançar uma gasolina da alta octanagem (Esso Maxxi Gold). Em 2000, foi anunciada a fusão entre a Esso (Exxon) e a Mobil. Em 2008, o distribuidor transferiu suas operações no Brasil para a Cosan. Em 2009/2010, a Esso-Cosan anunciou a formação da joint venture com a Shell.

Quadro 7 - Informações e dados Esso/Cosan

\begin{tabular}{|l|r|}
\hline Slogan & "Coloque um tigre no seu motor" \\
\hline *Loja de Conveniência & Stop \& Shop e Hungry Tiger \\
Faturamento mensal médio (R\$) & 242 \\
Área Média (m²) & 84.76 \\
82,7 \\
\hline Produtos aditivados do ciclo Otto & Gasolina de alta octanagem (Maxxi Gold) \\
Controle de Qualidade & Gasolina Aditivada (Maxxi) \\
\hline **Quantidade de postos em 2009 & "Combustível Garantido" \\
\hline **Participação de vendas nacionais da & 1.535 \\
gasolina (2009) & $6,64 \%$ \\
\hline **Participação de vendas nacionais do etanol & $5,05 \%$ \\
$(2009)$ & \\
\hline Fontes: **ANP, *Sindicom.
\end{tabular}




\subsection{Análise dos Resultados}

Nessa etapa, serão analisados os resultados das entrevistas destacando os assuntos sobre as dimensões da análise ambiental, das estratégias competitivas e a sustentabilidade em três capítulos a seguir:

\subsubsection{Macroambiente Clima}

Dentre as decisões governamentais mais impactantes nos negócios dos distribuidores de combustíveis, nos últimos nove anos (2000-2009), foi citado pelos gerentes dos distribuidores de combustíveis, o processo de desregulamentação como principal fator de mudanças e em segundo lugar a decisão governamental em promover o etanol como produto combustível alternativo à gasolina através do incentivo dado para a concretização dos carros flex fuel.

E, sendo assim, todos os gerentes dos distribuidores de combustíveis foram unânimes ao afirmarem que o processo de desregulamentação foi a decisão governamental que mais trouxeram implicações diretas para as suas organizações comprovando dessa forma tudo o que foi discutido e que foi analisado por vários autores aqui descritos, o que não representou nenhuma surpresa., Ramos (2006) e Shikida et al (2004) analisaram profundamente os efeitos para as usinas e os agricultores. Maistro (2002), Nunes e Gomes (2005) e Dalmonech et al (2005) destacam os efeitos para os distribuidores.

G.BR salienta que o mercado mudou completamente, fez lembrar que além dos preços tabelados, a localização e o funcionamento dos postos de combustíveis também era determinado pelo governo; não era possível abrir posto em qualquer lugar, era proibido abrir aos domingos e durante a semana tinha horário determinado para fechar. A venda 
se resumia a venda da gasolina e o revendedor basicamente "sentava no banquinho e esperava o dinheiro entrar no bolso" 24 .

A desregulamentação trouxe um complicador que o revendedor de combustível não estava habituado primeiro a competir com outros postos e depois competir com o mercado informal, esse cenário motivou a saída de muitos revendedores.

Ainda de acordo com G.BR, esse efeito acabou trazendo uma sobrecarga para a organização obrigando-a a investir e em qualificar seus funcionários com treinamentos adequados. Um outro ponto em destaque é a própria revenda que demorou para aceitar e até mesmo se adequar às novas condições impostas pelo ambiente. Com a introdução dos carros flex fuel e o índice crescente das vendas do etanol gerou um clima de tensão no relacionamento entre revendedor e distribuidor, a razão disso se deve a variação de preços do etanol que ocorreu praticamente por semana, o que não acontece com a gasolina, sendo o etanol um produto agrícola, sazonal e dificilmente se consegue realizar uma previsão de vendas maior que um mês.

G.IPI menciona que apesar do governo iniciar o processo de desregulamentação na década de 1990, várias liminares foram criadas até alguns anos atrás o que de uma certa forma, o mantinha ainda muito presente no setor. Maistro (2002) faz lembrar, que o processo de desregulamentação foi iniciado em 1996 com a liberação parcial dos preços da gasolina e do etanol e somente em 2002, o preço passou a ser inteiramente regulados pelo mercado. Para o G.IPI no momento em que o governo deixou de conceder essas liminares, a Ipiranga conseguiu recuperar parte das vendas que antes acabavam sendo desviadas de alguma forma para o mercado informal. Outro ponto marcante para a Ipiranga, de acordo com G.IPI se referiu a reforma tributária na gasolina e a inserção da CIDE; além disso, a maior fiscalização contra a sonegação de impostos fizeram surtir efeito positivo direto para empresa com o aumento no volume de vendas.

Para Shell A, uma das medidas mais importantes para o setor como um todo foi regulamentação da substituição tributária na gasolina. Após essa determinação observou-se claramente, na opinião de Shell A, a redução do mercado informal. Neste

\footnotetext{
${ }^{24}$ Transcrição da entrevista realizada em 11 jul 2011.
} 
mesmo aspecto Shell B, menciona que realmente o processo de desregulamentação foi "bastante traumático e prejudicial para todo o setor"25. Mas, a decisão governamental em promover o etanol como combustível trouxe implicações para organização que vai desde a programação de vendas até o processo de compra à logística se tornou necessário para desenvolver um expertise especial para lidar com um produto agrícola e sazonal,completamente diferente da realidade da qual os distribuidores de combustíveis de gasolina estavam acostumados.

Para o G.Esso/Cosan, a Esso/Cosan não acreditava que o etanol pudesse se tornar uma fonte energética viável e a decisão governamental em promover o etanol através do carro flex fuel entrava em conflito direto com a visão estratégica da corporação. G.Esso/Cosan acredita inclusive que com o passar dos anos, o aumento da frota flex fuel no país, em conseqüência ao aumento do volume de vendas do etanol e a acentuada perda de margens tenham favorecido para que a organização vendesse sua participação de mercado para a Cosan em 2008.

Outro ponto mencionado por G.IPI é que a penetração do etanol é bem diferente em outras regiões do país e as generalizações devem considerar essas diferenças regionais. Nas cidades mais frias do país como nas cidades da região Sul o etanol, por exemplo, não se configura uma boa alternativa, pois o combustível como está desenvolvido atualmente, não tem bom desempenho na partida do veículo em dias de frio, garante G.IPI. Shell A explica que a maior penetração do etanol no estado de São Paulo pode ser atribuída há dois fatores: maior proximidade região produtora, (Ramos (2006) afirma que as maiores usinas de etanol estão localizadas no Estado de São Paulo) e o segundo fator se deve ao menor percentual do ICMS no país (demonstrado na Ilustração 1). G.BR acrescenta que o estado de São Paulo possui a maior frota de veículos flex fuel do país o que certamente influencia diretamente nas vendas do etanol

Um ponto positivo foi perceber que todos os gerentes dos distribuidores de combustíveis acreditam que o cenário para o Macroambiente Clima será um governo cada vez mais fiscalizador. E por este motivo, acreditam que em muito breve o setor

\footnotetext{
${ }^{25}$ Transcrição da entrevista concedida em 16 jun 2011.
} 
estará livre do mercado informal ou pelo menos se tornarão tão pequenos que não serão capazes de provocar os efeitos colaterais atuais.

O que se pode concluir do Marcroambiente Clima está em linha com as idéias apresentadas por Almeida (2010) ao afirmar que é um ambiente difícil de prevê principalmente a longo prazo. E neste sentido, G.BR garante que a última década foi uma avalanche de mudanças em vários aspectos (socioeconômico, político e legal) dos quais não seriam possíveis de contextualizar e prevê o mercado atual.

De acordo com Dibb (1996) as organizações que forem capazes de desenvolver a habilidade de se antecipar as tendências desse ambiente poderão capitalizar algum tipo de vantagem competitiva. Essa é uma afirmação que não condiciona nenhum questionamento. Mas, diante dos relatos dos gerentes dos distribuidores de combustíveis o processo de desregulamentação e o lançamento dos carros flex fuel no Macroambiente Clima poderiam ser de alguma maneira percebido como tendência, em virtude do processo de abertura do mercado brasileiro, a privatização de várias empresas estatais, etc. Mas a constituição de um mercado informal e todas as conseqüências que surgiram com a entrada desses competidores no setor não foi em nenhum momento imaginado por nenhum dos distribuidores de combustíveis se transformando em um fator surpresa.

\subsubsection{Macroambiente Solo}

Os gerentes dos distribuidores de combustíveis mencionam que as transformações da sociedade brasileira vêm favorecendo em muitas oportunidades e como também desafios para suas organizações (Kotler Armstrong, 2007), entre elas o aumento da frota de veículos, o aumento do consumo dos combustíveis de maneira geral. A inserção de mais mulheres no mercado de trabalho favoreceu a ampliação da ofertas e melhorias nas lojas de conveniência. Os gerentes também já percebem que o nível educacional da população vem melhorando ao longo dos anos e de certa forma isso 
implica em consumidores mais exigentes e que demandam por novas formas de atendimento (Dibb, 1996).

Outro ponto comum entre os distribuidores de combustíveis se referiu aos benefícios da conquista da estabilidade econômica (Frank e Enkawa, 2009), é inegável dissociar as melhorias na qualidade de vida com o Plano Real.

Diante deste contexto, G.BR acredita que a estabilidade econômica criou um novo perfil de consumo, ou seja, as pessoas deixaram de fazer grandes compras mensais para compras menores e semanais. Com isso, propiciou as lojas de conveniência um amplo desenvolvimento nestes últimos anos. Para G.IPI, a maior explicação para o sucesso das lojas de conveniência no Brasil pode estar relacionado com o atendimento rápido e a excelente localização dessas lojas de conveniência que facilita a vida do consumidor, isso é tudo que o consumidor precisa. A loja de conveniência é praticamente uma loja de varejista em menores proporções.

A Ipiranga, de acordo com G.IPI, se destaca dos demais distribuidores por oferecer a maior variedade de itens e um programa de fidelidade bem amplo e as lojas AM/PM são praticamente uma loja varejista em menores proporções.

É importante destacar que a Ipiranga detém a maior participação de lojas de conveniência do país, ultrapassando inclusive a BR que é líder quase que absoluta em participação de mercado de combustíveis. Além da liderança na participação de mercado com as lojas AM PM, a Ipiranga vem mantendo o melhor desempenho em relação ao faturamento por metro quadrado da loja de conveniência (Tabela 5).

Com o objetivo de ilustrar a importância e a crescente representatividade das lojas de conveniência para os distribuidores de combustíveis será demonstrada na Tabela 5, a evolução do faturamento médio m por metro quadrado em 2003, 2005, 2007 e 2009, de acordo com o Sindicom. 
Tabela 5 - Evolução do desempenho das lojas de conveniência $\left(\mathrm{R} \$ \mathrm{~m}^{2}\right)$

\begin{tabular}{|l|c|c|c|c|}
\hline Distribuidores & $\mathbf{2 0 0 3}$ & $\mathbf{2 0 0 5}$ & $\mathbf{2 0 0 7}$ & $\mathbf{2 0 0 9}$ \\
\hline BR (BR Mania) & $\mathrm{R} \$ 460 / \mathrm{m}^{2}$ & $\mathrm{R} \$ 485 / \mathrm{m}^{2}$ & $\mathrm{R} \$ 485 / \mathrm{m}^{2}$ & $\mathrm{R} \$ 995 / \mathrm{m}^{2}$ \\
\hline Ipiranga (AM/PM) & $\mathrm{R} \$ 815 / \mathrm{m}^{2}$ & $\mathrm{R} \$ 891 / \mathrm{m}^{2}$ & $\mathrm{R} \$ 889 / \mathrm{m}^{2}$ & $\mathrm{R} \$ 1.543 / \mathrm{m}^{2}$ \\
\hline Shell (Select) & $\mathrm{R} \$ 741 / \mathrm{m}^{2}$ & $\mathrm{R} \$ 721 / \mathrm{m}^{2}$ & $\mathrm{R} \$ 863 / \mathrm{m}^{2}$ & $\mathrm{R} \$ 1.177 / \mathrm{m}^{2}$ \\
\hline $\begin{array}{l}\text { Esso-Cosan (Hungry Tiger / Stop \& } \\
\text { Shop) }\end{array}$ & $\mathrm{R} \$ 663 / \mathrm{m}^{2}$ & $\mathrm{R} \$ 703 / \mathrm{m}^{2}$ & $\mathrm{R} \$ 704 / \mathrm{m}^{2}$ & $\mathrm{R} \$ 1.025 / \mathrm{m}^{2}$ \\
\hline
\end{tabular}

Fonte: Sindicom

De acordo com Shell B, apesar de a Shell ter sido a primeira a trazer o conceito de lojas de conveniência para o Brasil, durante muitos anos foi relegado ao segundo plano; mas tem sido uma das prioridades da organização e mais uma vez foi a primeira a inovar com uma proposta diferenciada de contratos mais flexíveis para a revenda de combustíveis (Sindicom, 2004), isso motivou a expansão da rede. Para Shell A, as lojas Select foram inteiramente remodeladas, mudou-se o conceito, melhorou-se a imagem e os espaços foram melhores utilizados; criou-se também um conjunto de benefícios para o revendedor e para o consumidor através das parcerias firmadas com diversos fornecedores do varejo. Os dois gerentes salientam, porém que essas mudanças foram propiciadas em resposta as novas necessidades do consumidor. (Oliver, 1999).

G.Esso/Cosan atribui a crescente inserção da mulher no mercado de trabalho como um dos fatores que mais vem contribuindo para mudanças no atendimento ao consumidor. Na opinião de G.Esso/Cosan, as mulheres são muito mais exigentes do que os homens com questão de higiene, aparência dos funcionários e mais sensíveis aos aspectos de limpeza (Kotler e Caslione, 2009). Neste aspecto, há unanimidade entre os distribuidores de combustíveis de que as mulheres estão exigindo deles uma atenção maior aos detalhes do atendimento, da exposição dos produtos, da limpeza e aparência dos funcionários. As lojas de conveniência da Esso/Cosan passaram por uma remodelagem e mudou o conceito do cafezinho para uma oferta mais ampla com sanduíches, bolos e sobremesas, visando atender as novas demandas emergentes.

Por outro lado, quando os distribuidores foram questionados sobre as mudanças observadas no último censo realizado pelo IBGE em que foi observado um maior crescimento da população residente do país nas regiões Norte, Nordeste e Centro-Oeste e uma queda da população residente nas regiões sul e sudeste e essa mesma relação pode ser estabelecida com a frota de veículos. Questionou-se como essa migração de 
pessoas poderia afetar de alguma maneira suas organizações. Além disso, buscou-se saber se já estão sendo direcionando maiores investimento para essas regiões prevendo uma maior população residente lá.

Em linhas gerais, com exceção do G.BR, foi exposto que ainda são mudanças ainda muito tímidas e que não motivam maiores investimento dos distribuidores de combustíveis. Para G.BR, a BR além de líder em participação de mercado é também o único com presença em todos as regiões do país. E neste sentido, acredita, que antes de mais nada a BR tem um papel social a cumprir, e em alguns casos específicos, mesmo em que o resultado financeiro da operação pretendida, não se configure o desejado, pode ainda assim seguir com a execução do negócio se este for significante para a região. G.BR lembra antes de mais nada que os postos de combustíveis são importantes fontes empregadoras e pode se tornar importante para pequenos municípios.

Considerando as diferenças regionais do país foi questionado aos distribuidores de combustíveis se, como sugere Kotler (2000), segmentam clientes ou mercado de acordo com as regiões, e assim oferecem uma oferta diferenciada. Os distribuidores foram claros ao afirmar que existe sim uma segmentação de mercados e clientes, mas que nenhum deles de fato propõe diferentes ofertas para cada tipo de cliente. G.BR menciona que em um mercado de combustíveis é um negócio baseado na economia de escala e seria impossível gerenciar toda a cadeia considerando as nuances regionais, a segmentação de clientes e mercados. Para Shell B, a segmentação de clientes é feita entre clientes do ciclo Otto e postos com expressiva venda de diesel. Praticamente essa é a segmentação utilizada por todos os distribuidores de combustíveis. Todos eles apresentam um plano de marketing anual diferenciando o cliente pelo produto mais vendido, mas isso não implica que para cada região do país, se tenha uma oferta diferenciada, isso pode se configurar uma oportunidade. 


\subsubsection{Ambiente Operacional}

O ambiente operacional vem sofrendo profundas mudanças nos últimos anos. O carro flex fuel influenciou definitivamente as relações entre os agentes do setor fornecedores, competidores e clientes. $\mathrm{O}$ interessante que pode ser notado durante as entrevistas é que os gerentes dos distribuidores de combustíveis acreditam que o setor poderá ser inteiramente reformulado diante as novas possibilidades em termos de motores automotivos e novos combustíveis. Porém, para eles, o etanol ainda se configura para eles um grande desafio para a distribuição e acreditam que os próximos anos será ainda mais desafiador.

G.BR afirma que a tarefa mais difícil, atualmente é adequar a logística de distribuição de combustíveis ao etanol devido a falta de infra estrutura no Brasil e ainda assim continuar a crescer. G.BR relata que quando a demanda é alta e é necessário uma frota maior de caminhões o que ocorre é não ter caminhões. Ora é a chuva que dificulta toda a operação ora são as rodovias que ficam estranguladas e ocasiona atraso em toda a operação logística. Outro grande complicador na logística e suprimento do etanol é gerenciar os modais logísticos, geralmente a entrega é feita por caminhões, mas pode ser utilizado os portos marítimos, ou ainda por via férrea utilizando os vagões de trens de cargas e essa decisão depende entre outros fatores basicamente da origem de compra do etanol.

Esse cenário era desconhecido quando só se tinha os derivados de petróleo para se distribuir. Para G.IPI, o grande complicador operacional no gerenciamento do etanol foi passar a ter vários fornecedores quando antes se tinha um único que era a Petrobras.

Em relação aos concorrentes os gerentes dos distribuidores de combustíveis acreditam que a tendência é a consolidação de grandes grupos e possivelmente será observado nos próximos anos, compra e aquisição das pequenas e médias usinas por esses grandes grupos já bem estabelecidos e bem mais acentuados. No curto prazo não acreditam que novos competidores se arriscarão a ingressar no Brasil, em virtude da complexidade única e exclusiva do país. Sendo assim, no curto/médio prazo provavelmente haverá 
apenas 3 grandes distribuidores (BR, Ipiranga e Joint Venture-Shell/Cosan) com uma crescente participação de mercado em relação aos distribuidores independentes.

No front tecnológico, G.BR acredita que o carro elétrico deverá ingressar no país nos próximos anos, mas não acredita que será uma tecnologia predominante diante da falta de infraestrutura de rede elétrica no país, além disso menciona os problemas ambientais com a bateria atual.

G.Esso/Cosan acredita que este é um momento ainda muito difícil para prever a tecnologia automotiva ou mesmo o combustível que será predominante, porém acredita fortemente no desenvolvimento de novos biocombustíveis. Para ele, especificamente no Brasil, este é um caminho sem volta. G.Shell A e B acreditam no desenvolvimento de combustíveis de segunda geração, o que poderia torna o etanol viável. Shell B e G.Esso/Cosan acreditam que o etanol não será um produto a ser comercializado no Brasil, mencionam que com o pré-sal há grandes possibilidades de o país ter uma gasolina com preços mais competitivos que o etanol hidratado. Para eles, esse combustível será um produto exportação e internamente será utilizado apenas o etanol anidro como aditivo à gasolina.

No que tange os clientes, todos os gerentes dos distribuidores de combustíveis observaram que nos últimos anos o crescimento de muitos postos concentrados em apenas alguns revendedores. Na perspectiva do cliente essa é uma maneira de garantir melhores preços e condições. Contudo, para Shell B, os distribuidores de combustíveis devem acompanhar esse processo com muito cuidado e critério, visto os riscos inerentes nessa relação. Já G.BR, menciona que o lado positivo dessa relação é ter revendedores capitalizados que dão uma dinâmica bem diferente do que era visto tempos atrás em que o postos de serviço era uma empresa familiar completamente dependente do distribuidor. Para G.Esso/Cosan essa será a tendência dos próximos anos sendo uma repetição do que aconteceu em outros negócios. Shell A enfatiza que isso se deve a necessidade de diminuir custos e aumentar a escala.

$\mathrm{Na}$ opinião de Shell $\mathrm{B}$, os distribuidores deixarão de competir por clientes para competir por redes de clientes. E prevendo esse futuro próximo, a Shell vem investindo 
com para reforçar sua oferta de valor e estar mais próximo possível do revendedor buscando se antecipar e atender as suas necessidades e anseios.

Em linhas gerais, o ambiente operacional parece incerto e imprevisível. Porém, é esperado novas tecnologias automotivas, novas opções de combustíveis, grandes e gigantes grupos como concorrentes, acirramento da competição por redes de clientes.

\subsection{Estratégias Competitivas}

Este capítulo está dividido em duas partes: a primeira parte, será relacionada com as estratégias competitivas propostas por Zaccarelli e Fischmann (1994) com as percepções dos gerentes dos distribuidores e combustíveis; na segunda parte, será realizada uma discussão sobre cada organização separadamente. Seguida de algumas observações gerais sobre as estratégias de despistamento, cooperação, agressão e autoproteção.

Em relação a estratégia de evolução ficou claro que a BR e a Shell utilizam como ferramenta de prospecção - cenários. E projetam suas organizações para atuarem dentro dessas perspectivas. Não foi possível concluir através das entrevistas quais a ferramentas eram utilizadas pela Esso/Cosan e pela Ipiranga. Contudo, é possível inferir que a Esso/Cosan possivelmente utilize como ferramenta o monitoramento.

Em relação à estratégia de despistamento, todos os gerentes dos distribuidores acreditam que essa é uma estratégia que dificilmente é mantida por longo período de tempo (Golçalvez et al, 2006) mas, certamente, é utilizada pelas organizações quando assim é necessário. G.BR não acredita porém que o carro flex fuel tenha favorecido a intensificação desta estratégia em específico, pois salienta que essa é uma decisão organizacional. G.IPI apesar de não negar a existência da estratégia de despistamento, acredita que a utilização dela poderá trazer efeitos contrários para a organização despertando o interesse e curiosidade dos concorrentes, principalmente. G.Esso/Cosan 
enfatiza inclusive que o abuso dessa estratégia poderá colocar a própria imagem da organização em risco com a perda de credibilidade nas informações (Porter, 2004).

Quando se refere à a estratégia de cooperação percebe-se que entre os distribuidores de combustíveis buscam um comportamento cooperador no que tange a facilidades de distribuição e logística, pois juntos conseguem redução de custos. Foi percebido também que depois do carro flex fuel esse relacionamento se tornou mais cauteloso como afirma G.BR. Na opinião dele, o aumento da competição não tem favorecido o desenvolvimento dessa relação, mas destaca que a BR e a Shell estão trabalhando juntas para a construção do etanol-duto. Por outro lado, todos os gerentes mencionam que não houve nenhuma alteração específica após a introdução dos carros flex fuel.

Já a estratégia de agressão buscou-se identificar se essa é uma prática comum no setor, e se é praticado por um dos distribuidores ou ainda se há a possibilidade de ataques entre os grandes distribuidores ${ }^{26}$ e os distribuidores bandeira branca, isso foi percebido pela autora empiricamente através de conversas informais com revendedores. G.IPI acredita que possa haver alguma relação entre os grandes distribuidores e os distribuidores independentes, mas não acredita ser uma prática muito comum no setor. Os demais gerentes também não acreditam que essa seja uma prática comum no setor como um todo.

Para a estratégia de autoproteção, foi destacado pelos gerentes da BR, Esso/Cosan e Ipiranga, a existência de lobby entre o governo e os usineiros de cana-de-açúcar. Para G.Esso/Cosan a pressão dos distribuidores de combustíveis com o governo tange na necessidade de se aplicar a reforma tributária do etanol hidratado o que não é de interesse das usinas. G.BR destaca que essa medida é eficiente e certamente agiria como um mecanismo regulador para combater a sonegação de impostos e assim favorecer um mercado livre de maus competidores como define Porter (1989). Mas, de acordo com G.IPI a discussão em pauta transita sobre de quem seria a responsabilidade para recolher os impostos, caso a substituição tributária se aplique ao produto também. Sobre o tema observou-se que os gerentes da Shell foram bastante cautelosos ao

\footnotetext{
${ }^{26}$ Grandes distribuidores lê-se BR, Ipiranga, Shell e Esso.
} 
afirmar ou negar a existência da estratégia de autoproteção, apenas, destacaram que no passado era mais comum do que é percebido atualmente.

Observou-se também as dimensões ambientais (MacroambienteClima, Macroambiente Solo e Ambiente Operacional) podem exercer maior influência em uma determinada estratégia competitiva dos distribuidores de combustíveis. Essa observação se baseou em identificar uma possível correlação entre as variáveis ambientais citada como exemplos utilizados pelos gerentes dos distribuidores de combustíveis para justificar uma determinada estratégia competitiva. Vale salientar que essa é uma observação empírica e necessita ser mais bem explorada.

Por outro lado, observou-se também que as mudanças pelo menos uma das dimensões ambientais tenham favorecido com maior intensidade alguma estratégia competitiva específica. Por exemplo, as dimensões clima e solo podem ter favorecido mudança na estratégia de intento da BR. A dimensão solo pode ter favorecido a expansão dos negócios da Ipiranga. A dimensão clima pode ter exercido maior influência para a estratégia de diferenciação funcional da Shell e de desinvestimento seguida pela Esso/Cosan.

\subsubsection{Apresentação dos resultados}

O Quadro 8 abaixo demonstra as opiniões dos gerentes dos combustíveis referente as perguntas relacionadas para cada uma das estratégias competitivas conforme proposta de Zaccarelli e Fischmann (1994). Quando mencionado “não observado mudanças' significa dizer que após a introdução do carro flex fuel não foi possível verificar ou inferir mudanças nas estratégias competitivas.

Um ponto a ser esclarecido, segundo os gerentes dos distribuidores de combustíveis é impossível dissociar o crescimento da frota de carros flex fuel com o crescimento das vendas do etanol. 
Ao iniciar a análise dos dados percebeu-se que a ferramenta de pesquisa, o roteiro de entrevista semi estruturado, não foi devidamente elaborado para fornecer as informações necessárias que pudessem auxiliar e identificar a estratégia competitiva de diferenciação funcional. Não foram exploradas informações que permitissem gerar conclusões sobre os quatro diferentes estágios dado a fabricação como propõem Wheelright e Hayes (1985). 
Quadro 8- Estratégias competitivas e as percepções dos gerentes dos distribuidores de combustíveis

\begin{tabular}{|c|c|c|c|c|}
\hline Estratégias & BR Distribuidora & Ipiranga & Shell & Esso/Cosan \\
\hline Oportunidade & Não observado mudanças. & $\begin{array}{l}\text { G.IPI menciona que o motorista do } \\
\text { carro flex fuel que abastece com } \\
\text { etanol necessita freqüentar mais } \\
\text { vezes o postos e isso favoreceu } \\
\text { ampliação do portfólio das lojas de } \\
\text { conveniência e melhorias no } \\
\text { atendimento. }\end{array}$ & Não observado mudanças. & Não observado mudanças. \\
\hline Desinvestimento & Não observado mudanças. & Não observado mudanças. & $\begin{array}{l}\text { Shell A menciona que a saída da } \\
\text { Shell no Centro-Oeste brasileiro } \\
\text { foi motivada pela forte presença } \\
\text { da informalidade na região e o } \\
\text { carro flex fuel possa sim ter } \\
\text { contribuído para esse cenário. } \\
\text { Segundo Shell A, essa foi uma } \\
\text { decisão tomada, pois o ambiente } \\
\text { da região não se encaixava com } \\
\text { os princípios corporativos e } \\
\text { nada teria haver com o carro } \\
\text { flex fuel. }\end{array}$ & $\begin{array}{l}\text { Na opinião de } \\
\text { G.Esso/Cosan o carro flex } \\
\text { fuel certamente influenciou } \\
\text { a decisão de saída do } \\
\text { Esso/Cosan no país. Os } \\
\text { biocombustíveis não se } \\
\text { configuram uma realidade } \\
\text { sustentável ao longo prazo } \\
\text { como se tem hoje. E a } \\
\text { crescente informalidade e } \\
\text { as perdas financeiras foram } \\
\text { decisivas para a decisão de } \\
\text { sair do país. }\end{array}$ \\
\hline Intento & $\begin{array}{l}\text { G.BR acredita que a organização } \\
\text { passou a se denominar como empresa } \\
\text { de energia e não mais uma empresa } \\
\text { que comercializa derivados do } \\
\text { petróleo. }\end{array}$ & Não observado mudanças. & $\begin{array}{l}\text { Não observado mudanças. } \\
\text { Shell A acredita que a formação } \\
\text { da joint venture ajuda a reforçar } \\
\text { a imagem corporativa desejada } \\
\text { pela Shell - uma empresa mais } \\
\text { bem preparada para enfrentar os } \\
\text { desafios energéticos. }\end{array}$ & Não observado mudanças. \\
\hline Adaptação & $\begin{array}{l}\text { Não observado mudanças, mas } \\
\text { acredita-se que o carro flex fuel tenha } \\
\text { evidenciado a necessidade de } \\
\text { profissionalismo da revenda e também } \\
\text { acentuou a segmentação de }\end{array}$ & $\begin{array}{l}\text { Parcerias com diversas empresas } \\
\text { fora do setor de combustíveis } \\
\text { propiciando maiores ganhos para o } \\
\text { cliente (revendedor) e o } \\
\text { consumidor. }\end{array}$ & $\begin{array}{l}\text { Os contratos se tornaram mais } \\
\text { flexíveis. E a relacionamento } \\
\text { entre distribuidor e o cliente } \\
\text { (revendedor) é o foco da } \\
\text { organização. Deseja-se estar }\end{array}$ & Não observado mudanças. \\
\hline
\end{tabular}




\begin{tabular}{|c|c|c|c|c|}
\hline & consumidores. & & $\begin{array}{l}\text { mais perto do cliente para } \\
\text { melhor compreender suas } \\
\text { necessidades. Redefinição do } \\
\text { portfólio. }\end{array}$ & \\
\hline $\begin{array}{l}\text { Diferenciação } \\
\text { Produto } \\
\text { Mercado }\end{array}$ & Não observado mudanças. & Não observado mudanças. & $\begin{array}{l}\text { Criação e desenvolvimento do } \\
\text { Etanol Aditivado. }\end{array}$ & Não observado mudanças. \\
\hline $\begin{array}{l}\text { Diferenciação } \\
\text { Funcional }\end{array}$ & $\begin{array}{l}\text { De acordo com G.BR a realidade atual } \\
\text { com o etanol e as questões ambientais } \\
\text { exigiram maior sinergia de outros } \\
\text { setores da organização. Sendo } \\
\text { necessário inclusive a contratação e } \\
\text { treinamento de pessoas para que } \\
\text { pudesse entender a nova dinâmica no } \\
\text { setor. }\end{array}$ & Não observado mudanças. & $\begin{array}{l}\text { Contratação } \text { de } r \text { pessoas } \\
\text { especializadas em compras, } \\
\text { negociação e comercialização } \\
\text { internacional (trade) do etanol. } \\
\text { Shell B menciona que não há } \\
\text { nenhuma reunião estratégica } \\
\text { sem considerar este setor. E isso } \\
\text { mudou depois que o etanol } \\
\text { passou a configurar importância } \\
\text { em volume de vendas. } \\
\text { Integração vertical no etanol. }\end{array}$ & Não observado mudanças. \\
\hline Inovação & $\begin{array}{l}\text { Nenhuma mudança estratégia } \\
\text { observada. Contudo, a BR vem } \\
\text { inovando sistematicamente para } \\
\text { atender melhor o consumidor então } \\
\text { trouxe o Pit Stop que é uma } \\
\text { ferramenta que tornou o abastecimento } \\
\text { mais rápido. No site disponibilizou um } \\
\text { canal exclusivo para as mulheres com } \\
\text { dicas e informações relevantes para o } \\
\text { público feminino. Por enquanto, é a } \\
\text { única entre os distribuidores a oferecer } \\
\text { essas } \\
\text { ferramentas. }\end{array}$ & $\begin{array}{l}\text { G.IPI acredita que o carro flex fuel } \\
\text { e o consumo do etanol favoreceu o } \\
\text { aumento de visitas do consumidor } \\
\text { ao posto. E este cenário permitiu a } \\
\text { organização inovar } \\
\text { atendimento. no }\end{array}$ & Não observado mudanças. & Não observado mudanças. \\
\hline Evolução & $\begin{array}{l}\text { Não observado mudanças. } \\
\text { Mas, G.BR menciona que a BR faz } \\
\text { estudos sobre as tendências futuras e } \\
\text { uma forma de se antecipar a elas no }\end{array}$ & Não observado mudanças. & $\begin{array}{l}\text { Não observado mudanças. } \\
\text { Acredita que a joint venture } \\
\text { formada com a Cosan foi } \\
\text { motivada justamente por que é }\end{array}$ & Não observado mudanças. \\
\hline
\end{tabular}




\begin{tabular}{|c|c|c|c|c|}
\hline & $\begin{array}{l}\text { que a empresa acredita é pesado } \\
\text { investimento sendo realizado para a } \\
\text { construção dos etanóis-dutos. A } \\
\text { compra de usinas e investimentos que } \\
\text { estão sendo realizados para viabilizar } \\
\text { os biocombustíveis. }\end{array}$ & & $\begin{array}{l}\text { uma organização que investe } \\
\text { pesadamente em estudos de } \\
\text { cenários para o estudo de } \\
\text { tendências futuras. Shell B } \\
\text { acredita veementemente que a } \\
\text { negociação com a Cosan é uma } \\
\text { resposta para o futuro. }\end{array}$ & \\
\hline Reação & Não observado mudanças. & Não observado mudanças. & Não observado mudanças. & Não observado mudanças. \\
\hline Despistamento & $\begin{array}{l}\text { Não observado mudanças. } \\
\text { G.BR acredita que a Shell faz isso } \\
\text { muito bem, mas não acredita que o } \\
\text { carro flex fuel tenha estimulado isso. } \\
\text { Essa é uma estratégia de cada } \\
\text { organização e na opinião dele de } \\
\text { alguma forma todas utilizam desta } \\
\text { estratégia em algum momento. }\end{array}$ & $\begin{array}{l}\text { Não observado mudanças. } \\
\text { G.IPI acredita que é muito difícil } \\
\text { se manter essa estratégia. Além } \\
\text { disso, a quantidade de informações } \\
\text { disponíveis hoje, a concentração de } \\
\text { mercado existente os pequenos } \\
\text { blefes poderá colocar na verdade a } \\
\text { organização em uma exposição não } \\
\text { desejada, pois esse é um setor em } \\
\text { que os investimentos são altos e de } \\
\text { longo prazo. Mais cedo ou mais } \\
\text { tarde é descoberto. }\end{array}$ & $\begin{array}{l}\text { Não observado mudanças. } \\
\text { Os dois gerentes mencionam } \\
\text { que essa é uma estratégia que } \\
\text { pode ser adotada quando } \\
\text { necessário por todas as } \\
\text { empresas e de qualquer setor. }\end{array}$ & $\begin{array}{l}\text { Não observado mudanças. } \\
\text { G.Esso/Cosan não } \\
\text { acredita particularmente } \\
\text { que essa seja uma } \\
\text { estratégia capaz de se } \\
\text { sustentar por muito tempo } \\
\text { e acha inclusive que o } \\
\text { risco do descrédito no } \\
\text { mercado é muito grande } \\
\text { não valendo a pena seguir. }\end{array}$ \\
\hline Cooperação & $\begin{array}{l}\text { G.BR menciona que a Shell e BR } \\
\text { estão juntas para construção dos } \\
\text { etanóis-dutos, mas destaca que o } \\
\text { diante da concorrência mais acirrada e } \\
\text { qualquer movimento possa se } \\
\text { configurar uma vantagem para o outro } \\
\text { concorrente ele observa que, nesta fase } \\
\text { atual, um desestímulo a cooperação. }\end{array}$ & $\begin{array}{l}\text { Não observado mudanças, mas } \\
\text { G.IPI acredita que o etanol não } \\
\text { favorece a cooperação entre os } \\
\text { competidores devido } \\
\text { descentralização da produção. }\end{array}$ & $\begin{array}{l}\text { Não observado mudanças. Mas, } \\
\text { Shell B acredita que etanol não } \\
\text { favorece a cooperação entre os } \\
\text { distribuidores de combustíveis. }\end{array}$ & Não observado mudanças. \\
\hline Agressão & $\begin{array}{l}\text { G.BR não acredita que essa seja uma } \\
\text { prática comum no setor. }\end{array}$ & $\begin{array}{l}\text { G.IPI afirma que não é declarado, } \\
\text { mas de uma certa forma é uma } \\
\text { prática natural dos mercados } \\
\text { competitivos. }\end{array}$ & $\begin{array}{l}\text { Os dois gerentes não acreditam } \\
\text { nessa estratégia. Mas, Shell B, } \\
\text { menciona que as ações são } \\
\text { prejudiciais ao setor como um } \\
\text { todo e não acredita em uma } \\
\text { ação contra empresa. }\end{array}$ & $\begin{array}{l}\text { G.Esso/Cosan acredita na } \\
\text { possibilidade da existência } \\
\text { desta estratégia, mas não } \\
\text { acredita que seja uma } \\
\text { pratica comum no setor. }\end{array}$ \\
\hline
\end{tabular}




\begin{tabular}{|c|c|c|c|c|}
\hline Autoproteção & $\begin{array}{l}\text { G.BR acredita que ainda existem } \\
\text { muito lobbies a serem quebrados } \\
\text { especialmente para o etanol. A questão } \\
\text { tributária do produto ainda não foi } \\
\text { solucionada por haver ainda forte } \\
\text { pressão dos de alguns agentes da } \\
\text { cadeia* que é beneficiado de alguma } \\
\text { forma com o sistema atual. O desejo é } \\
\text { que as usinas passem a recolher o } \\
\text { imposto, como já é na gasolina }{ }^{27} \text {. Isso, } \\
\text { na opinião de G.BR certamente } \\
\text { dificultaria as algumas das ações } \\
\text { ilícitas praticadas no setor. } \\
\text { *subentendeu-se pequenas usinas e } \\
\text { distribuidores independentes. }\end{array}$ & $\begin{array}{l}\text { G.IPI acredita que a questão } \\
\text { tributária do etanol é demorada de } \\
\text { ser solucionada em virtude dos } \\
\text { lobbies políticos. }\end{array}$ & $\begin{array}{l}\text { Shell A acredita que essa foi a } \\
\text { realidade do passado e que não } \\
\text { se configura uma realidade hoje. } \\
\text { Shell B, afirma que certamente } \\
\text { existem algumas proteções } \\
\text { especiais do governo } \\
\text { especialmente, mas como Shell } \\
\text { A não acredita que seja um } \\
\text { problema atualmente tão grande } \\
\text { como foi no passado. }\end{array}$ & $\begin{array}{l}\text { Acredita que existe um } \\
\text { lobby muito forte entre } \\
\text { usineiro e o governo. }\end{array}$ \\
\hline
\end{tabular}

${ }^{27}$ A Petrobras recolhe antecipadamente o ICMS das gasolinas. 


\subsubsection{Análise das estratégias competitivas dos distribuidores de combustíveis}

A seguir será descrito as estratégias competitivas dos distribuidores de combustíveis adotadas no período de 2000 a 2009.

\subsubsection{BR Distribuidora}

Para G.BR, é possível que o carro flex fuel tenha influenciado de alguma maneira uma mudança significativa de como a organização se projeta para o futuro de uma empresa de petróleo para uma empresa de energia. Salienta, G.BR que muitos investimentos estão sendo realizados para desenvolvimentos de novos produtos como diesel da canade-açúcar e gasolinas que poluam menos o ambiente. Acredita o gerente inclusive que em muito breve outras novidades surgirão nesse aspecto.

Ao se afirmar como uma empresa de energia, muito além de uma empresa de petróleo, é possível verificar que esta mensagem traduz as considerações de Prahalad e Hamel (2005) quando afirmam que o intento estratégico deverá implicar uma noção de direção, descoberta e destino. Mesmo para pessoas não ligadas a empresa a mensagem consegue traduzir claramente os desejos futuros da organização.

Quando se analisa as mudanças do Macroambiente Solo, as conseqüências observadas por G.BR foi uma segmentação mais acentuada entre consumidores. E que o carro flex fuel propiciou um ambiente entre consumidores mais sensíveis a preços e outros fiéis às marcas. Ainda neste pensamento, o gerente menciona que o consumidor do etanol é muito difícil de fidelizar. "o cliente do etanol é capaz de rodar $10 \mathrm{~km}$ para economizar centavos"28.G.BR afirma que a BR vem buscando se adaptar a esse novo perfil de consumidor e trabalhando para melhor atendê-lo. 
Quando se pensa no consumidor, G.BR afirma "ninguém gosta de entrar num posto para abastecer!" 28 e, pensando nisso, a BR vem desenvolvendo ferramentas para melhor atender esse consumidor. E, neste sentido, a organização desenvolveu em julho de 2010 para os clientes que se sentem desconfortáveis com o processo de abastecimento depois de adquirir o selo "Pit Stop". É um sistema desenvolvido para facilitar e tornar mais ágil o processo de abastecimento; o consumidor apenas precisa colar o adesivo que vem com um chip embutido, no pára-brisa do carro, ir até um posto da BR que tenha a tecnologia e abastecer, sem sair do carro ou oferecer informações pessoais para realizar o pagamento.

Outro ponto que de acordo com a G.BR é o crescimento do motorista feminino. Ele garante que esse público é muito mais exigente e requer uma atenção especial. G.BR menciona que é a BR a única distribuidora a desenvolver uma campanha exclusiva para o público feminino. Então, foi através do site que pode ser verificado um canal inteiramente dedicado às mulheres com dicas úteis sobre combustíveis, lubrificantes e direção como também temas específicos a esse público como por exemplo: amamentação e direção, demonstrando assim, um cuidado especial com o público feminino.

Em relação ao revendedor (o cliente), G.BR, acredita que as mudanças do ambiente obrigaram o revendedor a se profissionalizar. O contexto competitivo atual, o carro flex fuel e as mudanças da sociedade brasileiras representam hoje um cenário extremamente diferente do de décadas passadas, o que ainda é difícil de ser aceito pela revenda mais tradicional (mais antiga), conclui G.BR. Para isso a BR vem trabalhando fortemente para uma mudança de comportamento do revendedor oferecendo-lhe cursos, treinamentos para ajudá-lo a atender bem os consumidores, visto que o posto de combustível é em sua maioria empresas familiares, afirma G.BR.

A atitude da BR em relação ao seu cliente (revendedor) e o consumidor demonstra total consonância com o Hax e Wilde (1999) denomina solução total para o cliente. O foco da organização passa a ser uma preocupação em oferecer um amplo e variado pacote de

\footnotetext{
${ }^{28}$ Entrevista concedida em 11 jul. 2011.
} 
opções de produto e serviços. A participação de mercado é o item de total relevância para essas organizações. A própria BR confirma seu poder quando afirma em sua visão o objetivo de "Ser líder no mercado nacional de distribuição de derivados de petróleo e biocombustíveis" ${ }^{29}$.

Neste contexto, é possível inferir que possivelmente o carro flex fuel tenha acentuado a necessidade de profissionalismo da revenda e fazendo emergir a necessidade, por parte da BR em capacitar seus clientes para o novo contexto ambiental. Vale salientar, que G.BR deixou claro que a BR sempre ofereceu cursos e treinamento para seus clientes (revendedores) assim como funcionários desde o início de suas operações no país. Quando se refere aos consumidores é muito difícil estabelecer uma relação direta com os carros flex fuel e as ações que a BR desenvolveu nos últimos anos como a tecnologia Pit Stop e o portal eletrônico desenvolvido para o público feminino, pois acredita-se que possivelmente essas inovações ocorreriam sem a inserção do carro flex fuel.

O que não há dúvidas é que o carro flex fuel propiciou um ambiente mais competitivo e dinâmico de uma maneira única no mundo. O que significou para a BR a necessidade de contratar pessoas com um conhecimento mais profundo sobre a comercialização e a venda do etanol. Além disso, sistemas e ferramentas gerenciais foram adaptados para atender a nova realidade imposta pelo carro flex fuel.

Para G.BR, o etanol complicou muito o planejamento a longo prazo das organizações, pois agora o número de variáveis é muito extenso o que dificulta e muito o planejamento. O que obriga os distribuidores de combustíveis terem pessoas altamente capazes e conhecedoras deste mercado para poder competir eficientemente. De acordo com Zaccarelli e Fischmann (1994) a estratégia de diferenciação funcional é caracterizada por três ações que envolvem desde a necessidade de conhecer o sistema produtivo, envolver os funcionários para a implementação e por fim monitorar o ambiente constantemente.

Percebeu-se durante a entrevista que os departamentos atualmente dentro da BR necessitam atuar mais sinergicamente. A equipe de vendas está muito mais próxima do

\footnotetext{
${ }^{29}$ Disponível em $<$ http/www.br.com.br $>$ acessado em 7 jul.2011
} 
setor que compras visto que etanol sofre variações semanais. Quaisquer erros nas projeções de venda e de compra podem resultar em prejuízos enormes em estoques. A equipe de marketing precisa estar ainda mais alinhada com vendas para compreender as demandas emergentes do consumidor. E o carro flex fuel, certamente, favoreceu para gerar tamanha complexidade, garante G.BR.

Imagina-se que a idéia de se ter o etanol como combustível substituto à gasolina tenha causado grande resistência por parte das pessoas dentro da BR por ser uma empresa tradicionalmente voltada para o petróleo. Acredita-se que a organização tenha investido muita energia para quebra de paradigmas organizacionais. G.BR menciona que o produto ainda hoje é um complicador operacional, é motivo tensões no relacionamento com o cliente devido a alta volatilidade e variação de preços semanal.

E assim é possível concluir que para a BR o carro flex fuel possa ter exercido alguma influência para mudanças na estratégia de intento e diferenciação funcional.

\subsubsection{Ipiranga}

O consumo do etanol como combustível implicou em um maior número de abastecimentos no mês, pois o combustível é menos eficiente do que a gasolina. Para G.IPI essa foi uma oportunidade que está sendo amplamente explorada pela Ipiranga. As lojas de conveniência são hoje praticamente em loja varejista e vende-se de tudo um pouco. Através do bem sucedido programa de fidelidade "KM de Vantagens", o consumidor pode trocar pontos adquiridos com o consumo de quaisquer produtos da Ipiranga por qualquer mercadoria disponível nas lojas ou no site da empresa.

G.IPI salienta que há uma clara relação de influência do carro flex fuel com o desempenho de venda das lojas. Quando o etanol perde paridade de preço para a gasolina a conseqüência direta é queda nas vendas das lojas de conveniência. 
Como descreve Zaccarelli e Fischmann (1994) esta estratégia está voltada para atender eventuais oportunidades que acontecem por um determinado período de tempo. O que se observa, nos período de safra, em que geralmente o preço do etanol é mais competitivo que a gasolina, o consumidor é obrigado a freqüentar mais vezes o posto e o que incentiva por sua vez as vendas das lojas de conveniência. Em períodos de entressafra em que o etanol se torna, geralmente, menos competitivo em relação à gasolina, observa-se queda nas vendas do posto de serviços como um todo, garante G.IPI.

Um ponto que gerou curiosidade, mas não pode ser explorado é o ciclo de ofertas da Ipiranga nos períodos de safra e entressafra. Seria interessante analisar as ofertas do site, cadernos promocionais da organização para verificar se há alguma estratégia diferenciada para esses períodos.

Nota-se, claramente, que a Ipiranga soube aproveitar uma oportunidade temporária em fonte de receita para todos envolvidos nesta operação. $\mathrm{O}$ cliente troca seus pontos por prêmios adquiridos com a compra e consumo de quaisquer produtos dentro os postos Ipiranga; o revendedor desenvolve outros canais de vendas e conquista um faturamento adicional; o distribuidor melhora as vendas de combustíveis da loja de conveniência e possivelmente outros setores do posto de combustíveis como a troca de óleo e a lavagem de carros, por exemplo.

Confirma Aaker (2007. 162) que o oportunismo estratégico é conduzido para que novos produtos, mercados e serviço sejam explorados e lançados. Para Kim e Mauborgne (2005) o grande desafio das organizações é transformar oportunidades em ciclos duradouros. O que parece que a Ipiranga vem conquistando.

Durante entrevista realizada com o revendedor A, ele mencionou que a Ipiranga conquistou uma dinâmica que nenhum outro distribuidor tenha conseguido fazer igual até o momento. $\mathrm{O}$ revendedor $\mathrm{A}$ mencionou que a Ipiranga desenvolveu um relacionamento intenso com diversos fornecedores e através deles vem conseguindo garantir benefícios para a própria organização, para o revendedor e para o cliente. Por trás do programa de fidelidade $\mathrm{KM}$ de vantagens, a Ipiranga consegue acordos diferenciados com os fornecedores para a venda dos produtos nas lojas $A M / P M$. A troca 
de benefícios é mutua, pois os fornecedores de eletrodomésticos, por exemplo, necessitam pagar altas taxas para terem suas marcas representadas no varejo tradicional. Nas lojas $A M / P M$ ou pelo site da Ipiranga (IpirangaShop.com ${ }^{30}$ ) conseguem expor o produto por um custo muito menor, a Ipiranga cobra um custo por isso e oferece para o revendedor a oportunidade de vender mais um item e o consumidor trocar por pontos ou ainda comprar por um preço que pode ainda ser menor que o do varejo tradicional.

Durante a entrevista realizada com G.IPI foi confirmado que a Ipiranga tem bons acordos com seus fornecedores, mas não se conseguiu explorar em profundidade o tipo de relacionamento e as transações comerciais implícitas aí estabelecidas.

Considerando que o carro flex fuel propiciou o aumento da freqüência em que o consumidor abastece seu veículo, é possível inferir que a Ipiranga construiu através dos seus fornecedores um conjunto de benefícios que para seus clientes e fornecedores.

Hax e Wilde (1999) atribuem esta estratégia de aprisionamento do sistema ou System Lock In. E essa é o mais amplo escopo da estratégia do modelo delta. E significa que ao invés de um foco baseado no consumidor ou no produto, a organização desenvolve a capacidade de envolver diversos agentes da cadeia e de outros negócios para agregar algum valor econômico em suas operações.

Quadros Jr (2005) lista duas condições básicas para que ocorra o aprisionamento do sistema das quais se observam com o programa criado pela Ipiranga. A primeira condição estabelecida pelo autor é o aumento do valor do produto ou serviços está proporcionalmente relacionado com o número de usuários. Esta primeira condição se encaixa perfeitamente, pois no momento em que mais consumidores se cadastram para participar do programa de fidelidade Ipiranga maior é o valor econômico do programa. A segunda condição é que a atratividade do negócio não deverá estar condicionada as suas características básicas, mas sim nos investimentos realizados por outros agentes externos à organização. E mais uma vez se observa a plena satisfação desta condição,

\footnotetext{
${ }^{30}$ Criado em 2008.
} 
visto que o benefício gerado para o consumidor estar baseado nas marcas de outros fornecedores.

Conclui-se para a Ipiranga que o carro flex fuel possivelmente influenciou mudanças estratégicas de oportunidade e de adaptação.

\subsubsection{Shell}

Com o aumento da competitividade surgiu também a intensificação de guerras em preços (Porter, 2004) e algumas regiões dessas guerras se estenderam por um período mais prolongado do que o esperado motivado principalmente por um mercado informal como afirma Shell A. Durante as entrevistas com os gerentes de Shell buscou-se explorar se a decisão de sair da região Centro-Oeste do país teria alguma relação direta ou indireta com o carro flex fuel. Entre os gerentes percebeu-se uma opinião contrária sobre o assunto. Shell A menciona em meados de 2003-2004 (não soube precisar o período) estava instalado forte presença do mercado informal, caracterizando um ambiente de maus competidores como sugere Porter (1989) e que o carro flex fuel (etanol) possam ter alguma relação nesse processo sim. Para Shell B, a resposta é mais objetiva e ele considera que a saída da empresa dessa região era incompatível com os princípios da organização e não acredita que flex fuel tenha alguma contribuição nesse processo.

Com o objetivo de explorar a visão de Shell B, foi questionado quais seriam as principais mudanças ocorridas no ambiente após o carro flex fuel. A primeira reposta confirma que o carro flex fuel propiciou a formação de um mercado informal. Questionou-se ainda se ele acreditava que se não houvesse o carro flex fuel, se ele ainda acreditava que mesmo assim esse tipo de competidor se configuraria no ambiente, e a resposta obtida foi negativa.

O que demonstra que não é possível afirmar categoricamente que o carro flex fuel tenha influenciado para estratégias de desinvestimentos da Shell, especificamente no Centro- 
Oeste. Por outro lado, Shell A e Shell B mencionam que o carro flex fuel tornou a análise de mercados mais crítica. Para elas, entre outras análises a primeira pergunta sobre investir ou não em um determinado mercado é verificar o preço de bomba (o preço ao consumidor) do etanol praticado. Em muitos casos, a organização pode não ter interesse em ter a presença em alguns mercados em virtude das baixas margens de uma determinada região por exemplo.

No que tange a estratégia de adaptação, os gerentes mencionam que a organização passou por uma reformulação dos contratos existentes, criou novas plataformas de oferta para o revendedor oferecendo-lhe mais opções e flexibilidade. Shell A, destaca que essa foi uma necessidade causada principalmente pelo aumento da competição. E certamente o carro flex fuel tem alguma relação indireta nesse processo. Shell B, destaca que as lojas de conveniência ganharam mais atenção da organização nos últimos anos e agora conta com visual muito mais moderno. Sendo essa uma postura adotada para principalmente recompor as perdas de margens atreladas a venda do etanol. Além disso, a empresa foi a primeira a inovar com uma proposta mais flexível dos contratos oferecendo além das usuais opções de franquia para um sistema de cobrança fixo em relação a metragem total da loja (Fecombustíveis, 2009).

De acordo, com Hax e Wilde (1999) as empresas buscam através do relacionamento mais próximo com seus clientes satisfazer todas as suas necessidades. Não é possível afirmar apenas com essas informações que a Shell é uma empresa utiliza como estratégia a solução total para o cliente, como definem Hax e Wilde (1999), mas foi possível perceber durante as entrevistas que a organização busca alinhar maneiras de atender às expectativas e necessidades emergentes de seus clientes.

Por outro lado, ficou claro que a Shell, durante as entrevistas, que o carro flex fuel propiciou a organização a se consolidar através da estratégia de diferenciação em produto, pois foi a primeira a lançar o etanol aditivado com o nome "Etanol V-Power" em 2009. Vale salientar que a empresa utiliza esse nome também para a gasolina aditivada. Com o etanol aditivado a Shell aumentou a família dos produtos diferenciados. Ansoff (1990) define que a estratégia de diferenciação em produtos diferencia o desempenho da organização dos que são ofertados pelos concorrentes. Os 
dois gerentes acreditam que a venda expressiva do carro flex fuel motivou a decisão da organização.

Mas, a grande influência do carro flex fuel para a Shell pode ser atribuída a formação da joint venture com a Esso/Cosan. Para Wheelwright e Hayes (1985) Shell B, declara ${ }^{31}$ "quando você sonharia em ver a Shell e a Esso juntas e formando uma única empresa? Nunca! Somente após o surgimento carro flex fuel essa formação se tornou possível." Shell B, acredita que o carro flex fuel tenha motivado a Shell ainda mais, pois a organização vem investindo pesadamente em pesquisas para o desenvolvimento de biocombustíveis e assim nada mais natural do que recorrer a integração vertical.

E possível concluir que certamente o etanol influenciou mudanças estratégia diferencial funcional, reforçou a estratégia de diferenciação em produto e pode ainda ter exercido algum tipo de influência na estratégia de desinvestimento e adaptação.

\subsubsection{Esso /Cosan}

$\mathrm{Na}$ opinião de G.Esso/Cosan o carro flex fuel foi um dos motivadores para a saída do Esso/Cosan do Brasil. É importante salientar, mais uma vez que a tecnologia apenas viabilizou um produto - o etanol, mas que por sua vez, favoreceu o surgimento entre bons e maus competidores como define Porter (1989). E as conseqüências foi o surgimento de um ambiente altamente competitivo como descreve Aaker (2007).

G.Esso/Cosan menciona que a estratégia organizacional da Exxon Mobil sempre foi muito clara em relação aos biocombustíveis. A organização vem investindo há alguns anos seriamente em pesquisa para o desenvolvimento de combustíveis não fósseis oriundo de algas e os de segunda geração, mas concluiu que até o momento não são uma opção financeira e econômica para ser adotada em larga escala. Isso não significa dizer que a organização não tenha compromisso com a sustentabilidade e com as

\footnotetext{
${ }^{31}$ Entrevista concedida em 16 jun.2011.
} 
reduções de emissões de $\mathrm{CO}_{2}$ na atmosfera, mas o caminho a ser percorrido para solucionar o esse dilema seria através do desenvolvimento de motores de gasolina e diesel mais eficiente que propiciem a redução de consumo e o desenvolvimento de combustíveis menos poluentes.

Diante da visão corporativa da Esso/Cosan fica claro que a decisão governamental em promover o etanol como combustível alternativo à gasolina em resposta ao dilema do aquecimento global e a necessidade de redução das emissões de poluentes na atmosfera se configurou completamente contraditório com a própria organização.

O carro flex fuel se torna uma realidade no país em 2003, mas G.Esso/Cosan afirma que a organização permaneceu centrada na sua estratégia organizacional sem demonstrar maior envolvimento com o produto. Porém, em 2005 com quase um milhão de carros flex fuel e 4,5 milhões de litros vendidos do etanol, representando quase $20 \%$ dos combustíveis comercializados no país do ciclo Otto, G.Esso/Cosan afirma que “acendeu uma luz vermelha ${ }^{32, " ~ n a ~ c o m p a n h i a . ~}$

Durante o período de 2003 a 2005, foi observada acentuada queda na participação de mercado e queda no número de postos de combustíveis (gráfico 2) tendo a marca Esso/Cosan representada. G.Esso/Cosan explica que as razões desses acontecimentos foram duas precisamente: a política de preços para o etanol se mostrou inconsistente para concorrer com o mercado informal o que justificaria a queda na participação de mercado; e a segunda razão foi a decisão da própria organização em não renovar alguns contratos por não serem respeitados pelos revendedores. G.Esso/Cosan considera que essa já foi uma decisão pensando na venda das operações Esso no Brasil, justamente para facilitar as possíveis futuras transações. É informado também que houve perda de importantes clientes (revendedores) motivados pelo baixo envolvimento da organização com o etanol.

G.Esso/Cosan afirma que a partir de então, observou-se o declínio dos investimentos da Exxon no país. Destaca que esse foi um período difícil para todos na organização e ainda mais difícil era fazer os reportes internacionais e tentar explicar a complexidade

\footnotetext{
${ }^{32}$ Entrevista concedida em 14 jun. 2011.
} 
que tinha se tornado o mercado brasileiro. Localmente a decisão foi baseada na manutenção da carteira de clientes e buscaram-se ferramentas para evitar a perda de novos e bons clientes. Neste momento se optou por uma nova política de precificação antes havia uma segmentação de preços de compra (detalhes não obtidos) e passou a ser uma condição única para todos os clientes. Essa medida, de acordo, com G.Esso/Cosan minimizou o desgaste com a revenda, o suficiente para manter uma rede de postos.

Esse contexto reforça as condições listadas por Aaker (2007) no que tange a estratégia de desinvestimento; da relação de seis itens se observou durante a entrevista pelo menos quatro delas a serem listadas abaixo. Não foi explorado se houve ou não mudanças da direção estratégia e nem mesmo as barreiras de saída. Por outro lado foi observado:

1. Índice de queda acentuado e acelerado não havendo demandas duradouras para a organização;

2. Duradouras e acentuadas guerras de preços motivadas por uma concorrência desleal;

3. Posicionamento da organização é fraco em relação aos concorrentes;

4. Os recursos administrativos e financeiros deixam de ser investidos.

Como afirmam Zaccarelli e Fischmann (1994) tendo a estratégia de desinvestimento como decisão se torna incompatível praticamente todas as estratégias contrárias a decisão, como a estratégia de inovação por exemplo. E assim, é possível concluir que para a Esso/Cosan, o carro flex fuel possivelmente exerceu forte influencia para a organização optar pela estratégia de desinvestimento.

\subsection{Sustentabilidade}

Durante as entrevistas ficou evidente que todos os distribuidores de alguma maneira buscam e atuam de forma socialmente responsáveis (Aligleri et al, 2009). Para G.Esso/Cosan, atuar de forma sustentável não é mais uma opção para as organizações e 
sim um imperativo do mercado atual, e afirma ainda que a Esso/Cosan também está fortemente engajada nas comunidades em que se faz presente.

$\mathrm{Na}$ percepção dos gerentes de combustíveis a revenda mais tradicional, ou seja, os revendedores mais antigos ainda se observam uma grande resistência. Shell A, menciona que a Shell vem ao longo dos anos promovendo cursos de conscientização ambiental para seus clientes e funcionários e acredita que a organização é a mais rigorosa no que tange o cumprimento das normas ambientais do que todos os demais concorrentes. $\mathrm{O}$ cuidado se estende a toda a organização dentro e for a dela.

Para G.IPI destaca que a Ipiranga será o primeiro distribuidor de combustíveis a ter um posto inteiramente "verde"; E explica que desde a construção até a operação destes postos foram projetados para proteger e preservar o meio ambiente. Ele destacou como os pontos principais, o reaproveitamento de água, sistema de ventilação projetada para economia de energia, instalação de lâmpadas mais eficientes e econômicas. Acredita ainda G.IPI, que a Ipiranga, neste quesito, está muito a frente dos competidores. A organização irá implementar o "cartão Ipiranga Carbono Zero" e o consumidor pode ainda trocar a pontuação obtida pelo programa de fidelidade (KM de vantagens) por créditos de carbono para neutralizar as emissões de $\mathrm{CO}_{2}$.

Os gerentes da Shell e a BR mencionaram o compromisso e a preocupação com o trabalho escravo e infantil nas lavouras de cana-de-açúcar. Afirmaram veementemente que as organizações se recusam a adquirir produtos de empresas que não atuem de maneira socialmente responsável.

O Sindicom (2004) menciona inclusive que as ações desenvolvidas pelos distribuidores existem antes mesmo delas terem se tornado uma regra. E relata inúmeras atividades, desde a década de 1940 com ações promovidas pelos distribuidores em diversas áreas como educação, esporte, cultura e defesa do meio ambiente.

Durante as entrevistas realizadas com os distribuidores de combustíveis o objetivo central era explorar e compreender como os clientes e consumidores percebem as ações defendidas pelos distribuidores de combustíveis. E tornou-se evidente que as bases da 
sustentabilidade para os gerentes dos distribuidores de combustíveis norteiam a responsabilidade socioambiental como sugerido por Aligleri (2011). 


\section{CONSIDERAÇÕES FINAIS}

A desregulamentação do setor de combustíveis pode ser considerada um marco na história dos distribuidores de combustíveis no país. Mas o lançamento dos carros flex fuel inseriu um capítulo a parte nessa história. A tecnologia flex fuel permitiu ao país redução do consumo das gasolinas; favoreceu aos consumidores redução dos gastos com combustível; favoreceu o aumento do número de competidores tornado a competição entre os distribuidores e postos de combustíveis uma competição de alta densidade (D'aveni, 1995). Mas, por outro lado, favoreceu surgimento entre bons e maus competidores (Porter, 1989).

Para compreender o processo de mudanças no ambiente dos distribuidores de combustíveis foi aplicada a análise ambiental sugerida por Almeida (2010). O autor definiu quatro dimensões, a saber: Macroambiente Clima (1), Macroambiente Solo (2), Ambiente Operacional (3) e Ambiente Interno (4). As variáveis do macroambiente clima são decorrentes das decisões do poder político; as variáveis do macroambiente solo estão relacionadas com as características populacionais, as variáveis do ambiente operacional se referem aos concorrentes, fornecedores e clientes e as relações futuras da organização com esses agentes; O ambiente interno é composto de informações únicas e exclusivas que caracterizam uma organização. Nessa pesquisa, o ambiente interno foi excluído da análise para se manter fiel ao objetivo de pesquisa.

Ao observar as significantes mudanças em todas as dimensões da análise ambiental, no período de 2003 a 2009, formulou-se o problema de pesquisa. E sendo assim, o problema de pesquisa está fundamentado na corrente teórica que considera que o ambiente influencia as estratégias competitivas das organizações (Almeida e Almeida, 2003). Questionou-se qual a influência da adoção do carro flex fuel na estratégia competitiva dos distribuidores de combustíveis?

Para identificar as possíveis estratégias utilizadas pelos distribuidores de combustíveis, no período de 2000 a 2009, foram adotadas treze estratégias competitivas diagnosticas por Zaccarelli e Fischmann (1994). São elas: oportunidades (1), desinvestimentos (2), 
intento (3), Adaptação (4), diferenciação de produto-mercado (5), diferenciação funcional (6), Inovação (7), Evolução (8), Reação (9), Despistamento (10), Cooperação (11), Agressão (12) e Autoproteção (13). A escolha e a aplicação deste modelo se justificaram diante da maior amplitude e flexibilidade.

Através dos resultados obtidos pelas entrevistas pode-se concluir que os carros flex fuel influenciaram em mudanças estratégicas nos distribuidores de combustíveis. Em relação à $\mathrm{BR}$, possivelmente, o carro flex fuel tenha influenciado as mudanças na estratégia de intento e na estratégia de diferenciação funcional. Para a Ipiranga é possivelmente que tenha influenciado mudanças na estratégia de oportunidade e adaptação. Para a Shell é possível que tenha influenciado mudanças na estratégia de diferenciação funcional, tenha reforçado a estratégia de diferenciação em produtos e exercido algum tipo de influência para estratégia de desinvestimento e adaptação, mas não foi possível validar essas duas últimas estratégias. Para Esso/Cosan tudo indica que o carro flex fuel tenha influenciado a estratégia de desinvestimento em que resultou a saída da distribuidora americana Exxon Mobil - Esso do país em 2008.

De acordo com G.BR, a BR sendo uma subsidiária da Petrobras, uma empresa voltada para o petróleo, o carro flex fuel implicou uma quebra de paradigma organizacional em que favoreceu o surgimento de uma nova empresa no próprio grupo, a Petrobras Biocombustíveis. Para G.BR claramente a Petrobras deixou de se denominar como uma empresa de "Petróleo" para uma empresa de "Energia". De acordo dom Prahald e Hamel (2005), essa nova visão deu a organização uma ampliação de escopo e de oportunidades de atuação. Em relação a estratégia de diferenciação funcional, o carro flex fuel, ao favorecer o etanol como produto alternativo a gasolina exigiu da BR a contratação de pessoas com maior conhecimento na cadeia da cana-de-açúcar para auxiliar o próprio entendimento organizacional sobre o etanol e as possíveis implicações deste produto à organização. Segundo G.BR foi necessário entre outras medidas, adaptação dos sistemas gerenciais e realizar treinamento com os funcionários. Além disso, favoreceu a compra de usinas de cana-de-açúcar, o que tornou a BR a única empresa no Brasil verticalmente integrada em relação à gasolina e ao etanol. Para Wheelwright e Hayes (1985), a integração vertical se configura uma importante mudança da organização em relação a fabricação no que tange a direção, extensão e equilíbrio. 
Durante o processo de análise dos resultados foi observado que a ferramenta de pesquisa não favoreceu analisar a estratégia de diferenciação funcional. Não foi possível identificar em qual dos quatro estágios da eficácia da fabricação, identificados por Wheelwright e Hayes (1985) estava antes e depois do carro flex fuel.

Para a Ipiranga, o carro flex fuel propiciou mudanças na estratégia de oportunidade e de adaptação. Em relação a estratégia de oportunidade, o carro flex fuel, favoreceu o consumo do etanol, que por sua vez, tem o poder calorífico menor do que a gasolina e obriga o consumidor a abastecer o automóvel mais vezes para rodar a mesma quantidade de quilômetros. Percebendo essa mudança de comportamento do consumidor, a Ipiranga passou a oferecer uma ampla variedade de produtos em suas lojas de conveniência. Contudo, quando o etanol perdia paridade de preços em relação à gasolina se observava queda nas vendas nos posto de combustíveis. Para incentivar as vendas a Ipiranga desenvolveu, em 2008, o site IpirangaShop.com, uma loja virtual que oferece uma ampla vasta gama de produtos. É possível afirmar, também, que o carro flex fuel tenha favorecido a Ipiranga a desenvolver a algo próximo da estratégia do aprisionamento do sistema como sugerem Hax e Wilde (1999). A Ipiranga passou a oferecer mais benefícios para os consumidores utilizando-se de agentes de diversos setores do varejo, que por sua vez, ampliam seus canais de vendas com um custo muitas vezes menor que o varejo tradicional e o revendedor ampliam as receitas do próprio posto. Como esta é uma técnica recente para a empresa e para o próprio setor ainda muito é cedo para afirmar categoricamente que a Ipiranga tenha alcançado o aprisionamento do sistema em perfeição. Contudo, até a conclusão dessa pesquisa nenhum distribuidor conquistou ou implementou a oferta da Ipiranga.

O carro flex fuel certamente influenciou a formação da joint venture da Shell com a Esso/Cosan no final de 2009, garantem os gerente das duas organizações. Mais uma vez, a integração vertical é utilizada para assegurar maior domínio sobre a fabricação como sugerem Wheelwright e Hayes (1985) e assim, é possível, inferir a influência direta dos carros flex fuel nesta decisão. Para a Shell, após a introdução dos carros flex fuel, a organização pode ampliar os produtos diferenciados com o lançamento do etanol aditivado. A organização conseguiu reforçar sua imagem de produtos diferenciados através da ampliação do portfólio. Em relação a estratégia de adaptação e 
desinvestimento não foi possível concluir uma relação direta do carro flex fuel nas mudanças dessas estratégias. Mas, foi a própria organização percebeu a necessidade de implementar mudanças no relacionamento com o cliente, tornando os contratos mais flexíveis como também o redesenho da proposta do negócio; o que demonstra consonância com a estratégia de foco total ao cliente de Hax e Wilde (1999). Por outro lado, os gerentes da Shell, acreditam que o carro flex fuel favoreceu o acirramento da competição no etanol e as guerras de preços em algumas cidades do país. Esse cenário contribuiu para mudanças na maneira como as avaliações de investimento são realizadas, se torna relevante atualmente saber o preço médio pago pelo consumidor no etanol assim como as características da concorrência (Porter, 1989). No que tange aos desinvestimentos, os gerente têm opinião contrária sobre a influência ou não do carro flex fuel para a retirada da marca na região Centro-Oeste, em meados dos anos 2003. Por este motivo, preferiu apenas afirmar apenas que existem sinais que favorecem a afirmação da influência, mas não pode ser conclusiva.

Para a Esso/Cosan, o carro flex fuel teve forte peso na decisão da Exxon vender suas participações para o grupo Cosan, afirma G.Esso/Cosan. Para o gerente, a estratégia organizacional da Exxon sempre foi muito clara em relação aos biocombustíveis. A organização não acredita que a realidade atual dos biocombustíveis não é sustentável ao longo prazo e que o futuro ainda será dominado por derivados do petróleo e a maneira mais racional de diminuir os efeitos colaterais dos combustíveis fósseis na atmosfera seria maiores investimentos para o desenvolvimento de carros mais econômicos e combustíveis mais eficientes. Quando as vendas do etanol atingiram participação significativa das vendas totais dos combustíveis, acredita G.Esso/Cosan que foi tomada a decisão de liquidar suas operações no Brasil

O que pode ser concluído desta pesquisa é que as mudanças nas dimensões ambientais influenciaram mudanças na estratégia competitiva dos distribuidores de combustíveis. Mas cada organização foi influenciada de forma diferente e essas buscaram encontrar soluções diferentes para os novos desafios e as novas oportunidades que surgiram.

È interessante notar, que essa pesquisa relata processo inicial do surgimento de uma nova tecnologia automotiva - os carros de motores flex fuel - e os primeiros anos de venda desses veículos. Em um seguimento secular como o de distribuição de 
combustíveis uma década é muito pouco tempo para analisar os efeitos ou até mesmo as conseqüências dessa tecnologia no ambiente dessas organizações. Ainda é impossível afirmar se será esse tipo de motor ou se será o etanol hidratado a melhor solução para diminuir a dependência do petróleo e/ou reduzir a poluição na atmosfera. Contudo, ficou claro que o setor jamais será como antes e tão pouco permanecerá como está por longos períodos como está atualmente. Novas tecnologias e novos produtos certamente surgirão.

O que não se pode negar também é que o etanol facilmente substitui a gasolina quando se pensa que esse também é um produto líquido e toda a infraestrutura mundial de distribuição está formatada para combustíveis líquidos. É um produto que polui menos a atmosfera quando comparado com a gasolina.

A introdução dos carros flex fuel no país favoreceu também o amadurecimento do setor numa velocidade muito intensa tornando-o mais competitivo e inovador. Os distribuidores necessitaram de fato repensar em suas estratégias competitivas para assegurar a própria existência o que criou no país uma dinâmica única e exclusiva do mercado brasileiro.

Como toda pesquisa nem sempre é possível estabelecer e explorar todas as variáveis encontradas e por este motivo será sugerido para as próximas pesquisas explorar melhor as proposições a seguir:

- Os gerentes dos distribuidores mencionaram que seus contratos com a revenda foram alterados e se tornaram mais flexíveis. Não foram explorados os aspectos de mudança dessa relação. Durante as entrevistas com os revendedores se observou o contrário das afirmações declaradas pelos distribuidores. $\mathrm{Na}$ opinião do revendedor $\mathrm{B}$, depois que o Brasil implementou a legislação ambiental os distribuidores passaram a não mais investirem em tanques e bombas em forma de comodato para a revenda temendo a responsabilidade solidária em caso de contaminação ambiental.

- Os distribuidores segmentam de alguma maneira os preços por cliente. Mas, não foi possível obter maiores detalhes dessa operação. Essa pode ser uma informação relevante para compreender a formação de preços 
entre o atacado e o varejo assim como também explorar formas de segmentação de preços e clientes nesse setor.

- Fine (1999), sugere que os mercados passam por ciclos de desenvolvimento e que forças internas e externas à organização favorecem o processo de centralização, descentralização, integração vertical e horizontal. Não foram encontrados estudos sobre esse processo em relação ao setor de combustíveis. E diante das mudanças observadas no setor torna-se importante compreender a forças motrizes desse processo.

- Todos os gerentes dos distribuidores de combustíveis mencionaram que a solução mais efetiva para o combate ao mercado informal no etanol seria a aplicação da substituição tributária. É necessário explorar outras alternativas como também conhecer as implicações dessa decisão e quais seriam os grupos de interesse.

- Com a consolidação do etanol no Brasil como combustível alternativo à gasolina e a possibilidade emergente de novas tecnologias automotivas serem lançadas no mercado, a dúvida é como as petrolíferas estão ou irão estar para concorrer com os biocombustíveis? O que pensam? Como estão se preparando para o futuro?

- Perfil do consumidor dos carros flex fuel. Não se conhece quem são esses clientes, as preferências e se a tecnologia influenciou mudanças no comportamento;

- É necessário explorar com mais profundidade quais as variáveis ambientais estão correlacionadas com mudanças em alguma estratégia competitiva.

Esta pesquisa possivelmente contribuiu para fortalecer a corrente teórica que considera que as organizações recebem e são influenciadas pelo ambiente do qual estão inseridas (Almeida 1997; Aaker 2007); fortaleceu também a corrente que acredita que em ambientes hipercompetitivos ou turbulentos é necessário desenvolver novas estratégias competitivas a fim de assegurar a própria existência da organização. (Brow e Eisenhardt, 1998; Kotler e Caslione, 2009; D'Aveni, 1995).

Outro ponto a ser considerado é que o carro flex fuel é praticamente uma realidade bem sucedida em larga escala, exclusivamente no Brasil. Desta forma, essa pesquisa 
propiciou uma breve discussão sobre as possíveis influências desta recente tecnologia na estratégia competitiva dos distribuidores de combustíveis.

Também foi possível uma leve abordagem sobre a sustentabilidade e a percepção dos gerentes dos distribuidores de combustíveis para esse tema tão recorrente e indispensável na atualidade.

Ainda assim, para muitos leitores poderá ampliar o conhecimento sobre os distribuidores de combustíveis no Brasil e a evolução do ambiente em que essas organizações estão inseridas.

Como se espera de uma pesquisa exploratória, essa contribuiu também por elencar diversos temas e assuntos que poderão ser abordados em estudos posteriores e aqui não foram possíveis abordar ou aprofundar. 


\section{REFERENCIA BIBLIOGRÁFICA}

AAKER, David A. Administração estratégica de mercado. 7. ed. Porto Alegre: Bookman, 2007.

ABRAMOVAY, Ricardo (organizador). Biocombustíveis: A Energia da Constrovérsia. São Paulo: Editora SENAC São Paulo, 2009.

Associação Brasileira de Normas Técnicas. NBR 6023: Informação e Documentação Referências - Elaboração. Rio de Janeiro, 2002.

ALIGLERI, Lilian Mara. Adoção de ferramentas de gestão para a sustentabilidade e a sua relação com os princípios ecológicos nas empresas. Tese de doutorado. Universidade São Paulo. São Paulo, 2011.

ALIGLERI, Lilian.et al. Gestão Socioambiental: responsabilidade e sustentabilidade do negócio. São Paulo: atlas, 2009.

ALMEIDA, Francisco Alberto Severo. Influência das políticas ambientais no desempenho empresarial econômico e socioeconômico: um estudo do setor de leite e derivados de Goiás. Tese de doutorado. Universidade São Paulo. São Paulo, 2010.

ALMEIDA, Martinho Isnard Ribeiro de. Planejamento Estratégico sendo Aplicado em Unidades de Organização e em Profissionais. In: IV SEMEAD, 1999, São Paulo. Seminário em Administração., 1999. Disponível em $<$ http://www.ead.fea.usp.br/eadonline/grupodepesquisa/martinho $>$ Acessado em 02 . ago.2009

Manual de planejamento estratégico: desenvolvimento de um plano estratégico com a utilização de planilhas Excel. 3.ed. São Paulo: Atlas, 2010.

Por que não desenvolver uma Análise Ambiental para o Planejamento

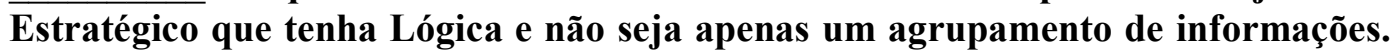
In: ANPAD, 1997, Rio das Pedras. ENANPAD- Encontro Anual da Associação Nacional dos Programas de Pós-Graduação em Administração., 1997 Disponível em $<$ http://www.ead.fea.usp.br/eadonline/grupodepesquisa/martinho> Acessado em 02. ago.2009

ALMEIDA, Martinho Isnard Ribeiro de; ALMEIDA, Francisco Ribeiro de. Análise do ambiente organizacional: a peça chave para o desenvolvimento de um planejamento estratégico. In: VI SEMEAD, 2003, São Paulo. Seminários em Administração, 2003. 
Disponível em $\quad<$ http://www.ead.fea.usp.br/eadonline/grupodepesquisa/martinho> Acessado em 02. ago.2009

ALMEIDA, Martinho Isnard Ribeiro de; MENEZES, Edgard José Carbonell. Será possível as pequenas e médias empresas cresceram sem informações do ambiente?. In: ANPAD - Encontro Nacional da Associação nacional dos Programas de PósGraduação em Adm., 1997, Rio de Janeiro. ENANPAD, 1997. Disponível em $<$ http://www.ead.fea.usp.br/eadonline/grupodepesquisa/martinho> Acessado em 02. ago.2009

ALMEIDA, Martinho Isnard Ribeiro de; FISCHMANN, Adalberto Américo. A globalização e os desafios estratégicos. In: SLADE, 1998, Cochabamba. Estrategias en la Incertidumbre - Congresso Latinoamericano de Estrategia, 1998. Disponível em $<$ http://www.ead.fea.usp.br/eadonline/grupodepesquisa/martinho $>$ Acessado em 02. ago.2009

ALMEIDA, Martinho Isnard Ribeiro de; OLIVA, Fábio Lotti . Criação de empresas ameaças e oportunidades pelos caminhos das estratégias genéricas. In: II EGEPE Encontro de Estudos Sobre Empreendedorismo e Gestão de Pequenas Empresas, 2001, Londrina. cd dos Anais do II EGEPE, 2001. Disponível em $<$ http://www.ead.fea.usp.br/eadonline/grupodepesquisa/martinho $>$ Acessado em 02 . ago.2009

ALVES, Henrique Abrahão. Plataforma de Apoio à Decisão da Inserção de Tecnologias em Produtos Aeronáuticos. Dissertação de Mestrado em Engenharia Aeronáutica e Mecânica, Sistemas Aeroespaciais e Mecatrônica. Instituto Tecnológico de Aeronáutica. São José dos Campos, 2009.

ANFAVEA - Associação Nacional dos Fabricantes de Veículos Automotores. Indústria automobilística brasileira: 50 anos. 2006. Disponível em $<$ http://www.anfavea.com.br> Acessado em 16 mai. 2009.

Anuário Anuário ANFAVEA 2010. Disponível em

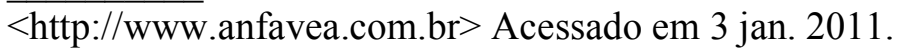

ANSOFF, H. Igor. The innovative firm. Long Range Planning. Dez. 1968. p.26-27.

A nova estratégia empresarial. São Paulo: Atlas, 1990.

ANSOFF, H. Igor; SULLIVAN, Patrick A. Optimizing profitability in turbulent Environments: A Formula for Strategic Success. Long Range Planning. v.26.n.5. ano 1993. p.11-23. 
BARROS, Ricardo Paes, et al. Analfabetismo no Brasil. Disponível em < http://www.iets.org.br/biblioteca/Analfabetismo_no_Brasil.pdf $>\quad$ acessado em 12.mai.2010.

BASS, Joseph. Innovation. San Francisco: MIT Sloan Management Review, 1997. (material de aula prof Eduardo Vasconcelos)

BERNARDINI JR. Plinio. Medindo a predisposição para a tecnologia. Tese de Doutorado. FGV. São Paulo, 2008.

BIROL, Faith. World energy propescts and challenges. Asia-Pacific Review. Mai.2007.

BOHMAN, Hakan. LINDFORS, Maj-Britt Johansson. Management for change: On the strategic change during recession. Journal of Business Research. n.41. 1998. p.57-70.

BRANDALIZE, Alexandre; BRANDALIZE, Adalberto. A estratégia da conveniência nos postos de combustíveis de Londrina. Revista Terra e Cultura - Cadernos de Ensino e Pesquisa. n.40. ano 21. Jan.Jul/2005. p.55-68.

BROWN, Shona L.; EISENHARDT, Kathleen M. Competing on the edge: Strategy as structured chaos. Boston: Havard Business School Press, 1998.

CARNEIRO, Jorge Manoel T; CAVALCANTI, Maria Alice F. D. Silva; FERREIRA, Jorge da. Porter Revisitado: Análise Crítica da Tipologia Estratégica do Mestre. RAC. V.1.n.3. Set./Dez. 1997. p.7-30.

CASTRO, Roberta Cristina Ferreira. Análise da preferência dos consumidores por álcool e gasolina segundo dados da POF 2002-2003. Tese de doutorado. Universidade São Paulo. São Paulo. 2007.

CERTO, Samuel C; PETER, J. Paul. Administração Estratégica: planejamento e implementação da estratégia. Núcleo de Gestão Empresarial. Disponível em < http://www.marcocoghi.com.br > acessado em 15.jan.2011.

CERTO, Samuel C. et al. Administração Estratégica: planejamento e implementação da estratégia. 2.ed. São Paulo: Pearson Education do Brasil, 2005. 
CHRISTENSEN, Clayton M. ROSENBLOOM, Richard S. Explaining the attacker's advantage: technological paradigms, organizational dynamics, and the value network. Research Policy, 1995. p. 233-257.

COSTA, Eliezer Arantes da. Gestão Estratégica: da empresa que temos para a empresa que queremos. 2.ed. São Paulo: Saraiva, 2007.

DALMONECH, Luiz Fernando. et al. Análise da relação entre as Distribuidoras e os Postos de Combustíveis: Um Enfoque a Luz da teoria dos Contratos, do Oportunismos e do Custo de Transação. IX Congresso Internacional de Custos Florianópolis, SC, Brasil, 28 a 30 de novembro de 2005

DIBB, Sally. The Impact of the Changing Marketing Environment in the Pacific Rim: Four Cases Studies. International Journal of Retail \& Distribution Management.v.24.n.11. p.16-29.1996.

D'AVENI, Richard A. Hipercompertição: Estratégia para dominar a dinâmica do mercado. Rio de Janeiro: Campus, 1995.

DICKEN, Peter. Global shift: reshaping the global economic map in the $21^{\text {st }}$ century. New York: The Guilford Press, 2003.

DI SERIO, Luiz Carlos (organizador). Clusters empresariais no Brasil: casos selecionados. São Paulo: Saraiva, 2007.

DUNCAN, W. Jack; GINTER, Peter M. Macroenvironmental Analysis for Strategic Management. Long Range Planning. v.23.n.6.p.91-100. 1990.

FECOMBUSTÍVEIS - Federação Nacional do Comércio de Combustíveis e de Lubrificantes. Relatório Anual da Revenda de Combustíveis 2009. Disponível em $<$ http://www.fecombustiveis.org.br/> Acessado em 15 set. 2009.

. Relatório Anual da Revenda de Combustíveis 2011. Disponível em $<$ http://www.fecombustiveis.org.br/> Acessado em 2 jan. 2011.

FERNANDES, Armando Wilson Alves. Análise sobre a prestação de serviços nos postos de revenda de combustíveis nos últimos anos. Dissertação de mestrado. Universidade São Paulo. São Paulo, 2001. 
FINE, Charles H. Mercados em Evolução Contínua: Conquistando Vantagem Competitiva num Mundo em Constante Mutação. Rio de Janeiro: Campus, 1999

FIGUEIREDO, Paulo N. Gestão da inovação: conceitos, métricas e experiências de empresas no Brasil. Rio de Janeiro: LTC, 2009.

FISCHER, Eileen et al. The sex the service provider: does it influence perceptions of service quality? Journal of Retailing. n.3.vol.73.1997. p361-382.

FRANK, Björn; ENKAWA, Takao. Economics Drivers of Dwelling Satisfaction: Evidence from Germany. International Journal of Housing Markets and Analysis. V.2.n.1.p.6-20, 2009.

GIL, Antônio Carlos. Métodos e técnicas de pesquisa social. 6. ed. São Paulo: Atlas, 2008 .

GIMENEZ. Fernando A. P. PELISSON, Cleufe. KRUGER, Eugênio G. S. HAYASHI, Paulo Jr. Estratégia em pequenas empresas: Uma Aplicação do Modelo de Miles and Snow. RAC. V.3n.2. Mai./Ago.1999.53-74.

GLÓRIA, Mariana P. Riveiro. Mercado cor-de-rosa: um estudo voltado para o ideal publicitário refletifo sobre a mulher brasileira. Anuário de Produção de Iniciação Cientifica Discente. n. 15. vol XII, 2011. p203-213.

Godói, Christiane Kleinubing et al (org). Pesquisa qualitativa em estudos organizacionais: paradigmas, estratégias e métodos. São Paulo: saraiva 2006.

GONÇALVES, Carlos Alberto. Estratégia empresarial: o desafio das organizações. São Paulo: Saraiva, 2006.

GUIMARAES, André Sathler. Estratégias competitivas adotadas por empresas de tecnologia da informação. Pontifícia Universidade Católica. Campinas. 2000.

GRUNDY, Tony. Rethinking and reiventing Michael Porter's five forces model. Strategic Change. v.15: p.213-229, aug. 2006.

HAIR Jr., Joseph F. et al Fundamentos e métodos de pesquisa em Administração. Porto Alegre: Bookman, 2005

HAMEL, Gary, Leading the revolution. Boston: Harvard Business Press, 2002. 
HANNAN, Timothy H; MCDOWELL, John M. The impact of technology and adoption on market structure. The Review of Economics and Statistics. n.1. vol.72, 1990. p.164-168.

HAX, Arnaldo C.; WILDE II, Dean L. The delta model: adaptative management for a changing world. Sloan Management Review, 1999. ano 40. p11-28.

HIRA, Anil. OLIVEIRA, Luiz Guilherme de. No substitute for oil? How Brazil developed its ethanol industry. Energy Policy. Vol 37.2009. p2450-2456.

HENDRY, John. The Problem with Porter's Generic Strategies. EMJ. vol.8 n.4. December, 1990.

HREBINIAK, Lawrence G. JOYCE, Willian F. Organizational Adaptation: Strategic choice and environmental determinism. Administrative Science Quarterly. n.3.vol.30. 1985. p336-349.

IPEA - Instituto de Pesquisa Econômica Aplicada. O Brasil em 4 décadas: textos para discussão. Disponível em <http://www.ipea.gov.br/> Acessado em 14 jan. 2010.

ILINITCH, Anne Y et all. New organizational forms and strategies for managing in hypercompetitive environments. Organization Science. n.3. vol.7. Special issue part 1 of 2: hypercompetition. 1996. p211-220.

LEWIS, Jordan D. Alianças Estratégicas: estruturando e administrando parcerias para o aumento da lucratividade. São Paulo: Pioneira, 1992.

KAMIMURA, Arlindo; SAUER, Ildo L. The Effect of flex fuel vehicles in the brazilian light Road transportation. Energy Policy, 2008.

KIM, W. Chan; MAUBORGNE, Renée. A estratégia do oceano azul: como criar novos mercados e tornar a concorrência irrelevante. Rio de Janeiro: Elsevier, 2005.

KOTLER, Philip; ARMSTRONG, Gary. Princípios de marketing. 12. ed. São Paulo: Pearson Prentice Hall, 2007.

KOTLER, Philip; CASLIONE, John A. Vencer no Caos: lições do guru de administração e marketing para uma gestão eficaz em tempos de turbulência. Rio de Janeiro: Elsevier, 2009. 
KOTLER, Philip - Administração de Marketing - $10^{\mathrm{a}}$ Edição, $7^{\mathrm{a}}$ reimpressão. São Paulo: Prentice Hall, 2000.

KUMAR, Nirmalaya et al. From market driven to market driving. European Management Journal. n.2. vol. 18. 2000. p.129-142.

UNIVERSIDADE SÃO PAULO. Manual para formatação e Edição de dissertações e teses. São Paulo, 2008.

MAISTRO, Marta Cristina Marjotta. Ajustes nos mercados de álcool e gasolina no processo de desregulamentação. ESALQ. Piracicaba, 2002.

McCONNELL, Campbell R; BRUE, Stanley L. Macroeconomia: Princípios, Problemas e Políticas. 14ª edição. Rio de Janeiro: LTC, 2001.

MONTGOMERY; Cynthia A. PORTER, Michael E. (organizadores) Estratégia: A busca pela vantagem competitiva. 2.ed. Rio de Janeiro: Campus, 1998.

MILES, R. E.; SNOW, C. C. Organizational strategy, structure, and process. Stanford Business Classics, 2003.

NUNES, Clemes; GOMES, Cleomar. Aspectos concorrenciais do varejo de combustíveis no Brasil. Associação Nacional dos Centros de Pós-Graduação em Economia - ANPEC 2005.

OLIVER, Richard W. Como serão as coisas no futuro. São Paulo: Negócio Editora, 1999.

VISÃO AGRÍCOLA. Cana-de-açúcar: cinco séculos fazendo história agrícola no país. USP ESALQ. ano 1. jan/jun. 2004.

VEJA. São Paulo. ed.278. p. 52-56. 2.jan.1974.

São Paulo. ed 628. p. 76-80.17 set. 1980.

PINTO, Mariana Rodigues; SILVA, Edmilson, Caputo Delfino. O brilho da bandeira branca: concorrência no mercado de combustíveis do Brasil. Associação Nacional dos Centros de Pós-Graduação em Economia - ANPEC, 2004. 
PORTER, Alan L. et al. Forescating and management of technology. Willey Interscience Publication. New York, 1991.

PORTER, Michael. Estratégia competitiva: técnicas para análise de indústrias e da concorrência. 2. ed. Rio de Janeiro: Elsevier, 2004.

Vantagem competitiva: criando e sustentando um desempenho superior.Rio de Janeiro: Elsevier, 1989.

PRAHALAD, C. K; HAMEL, Gary. Competindo pelo futuro: estratégias inovadoras para obter o controle do seu setor e criar os mercados de amanhã. Rio de Janeiro: Elsevier, 2005.

The Core Competence. Havard Busines Review. May-June. 1990.

RAMOS, Heidy. Proposição de estratégias para a produção de álcool carburante e Cuba. Dissertação de mestrado. Universidade São Paulo. São Paulo, 2006.

QUADROS Jr, Alfredo Cavalcanti. Orientação par ao mercado e o modelo delta de estratégia: um estudo de caso em empresa distribuidora de insumo para marcenarias. Dissertação de mestrado. Universidade São Paulo. São Paulo, 2005.

REIS, Valdir. Satisfação dos Consumidores em Postos de Combustíveis da Cidade de Blumenau. Universidade Regional de Blumenau. Blumenau, 2003

SACHS, Ignacy. Da civilização do petróleo a uma nova civilização verde. Estudos Avançados, 2005.

SACHS. Jeffrey D.; LARRAIN B. Felipe. Macroeconomia. São Paulo: Makron Books, 2000.

SALIH, Thamir M. Sustainable economic development and the environment. International Journal of Social and Economics. n. 1/2.vol 30. 2009. p. 153-162.

SMITH, Clayton G. Understanding technological substitution: generic types, substitution dynamics, and influence strategies. Journal of Engineering and Technology Management, 1992. p.279-302. 
SAMPIERI, et al. Metodologia de pesquisa. 3. ed. São Paulo: McGraw-Hill, 2006.

SANTOS, Cristina Tosta. Previsão de fabricação de carros bicombustíveis e de demanda de etanol no Brasil em 2014. Future Studies and Research Journal: Trends and Strategies. São Paulo, v.2.n.1.p85-98. Jan./Jun.2010.

SCHOEMAKER, Paul J.H. Scenario Planning: a tool for strategic thinking. Sloan Management Review Winter, 1995. p. 25-40.

SINDICOM - Sindicato Nacional das Empresas Distribuidores de Combustíveis e de Lubrificantes. Anuário de combustíveis \& lojas de conveniência, 2003.

Anuário de combustíveis \& lojas de conveniência, 2004.

Anuário de combustíveis \& lojas de conveniência, 2005.

Anuário de combustíveis \& lojas de conveniência, 2006.

Anuário de combustíveis \& lojas de conveniência, 2007.

Anuário de combustíveis \& lojas de conveniência, 2008.

Anuário de combustíveis \& lojas de conveniência, 2009.

Anuário de combustíveis \& lojas de conveniência, 2010

Anuário de combustíveis \& lojas de conveniência, 2011.

SILVA, Ozires; FISCHETTI, Décio. Etanol: A Revolução Verde e Amarela. São Paulo: BIZZ Comunicação e Produções, 2008.

SHIKIDA, Pery Francisco de Assis; BACHA, Carlos José Caetano. Evolução da agroindústria canavieira de 1975 a 1995. RBE, Rio de Janeiro. n.53. 1999. p.69-89.

SHIKIDA, Pery Francisco de Assis. et al. Agroindústria canavieira no Brasil: intrvencionismo, desregulamentação e neocoporativismo. Revista de Economia e Agronegócio. vol 2. n.3. ano 2004. p. 361-379. 
SOUSA, Rui et al. Customer heterogeneity in operacional e-service design attributes: an emprical investigation of service quality. International Journal of Operations \& Production Management. n.7. vol.28. 2008. p. 592-614.

SZKLO, Alexandre et al. Can one say etanol is a real treta to gasoline? Energy Policy. n.35. 2007. p.5411-5421.

SZULCZYK, Kenneth R. et al. Market penetration of ethanol. Renewable and Sustainable Energy Reviews. n.14. 2010. p.394-403.

TIDD, Joseph. BESSANT, John. PAVITT, Keith. Gestão da Inovação. 3. ed. Bookman, Porto Alegre,2008.

The most 10 read article on strategy. Harvard Business Review Press, 2011.

VEIGA, José Eli da. Desenvolvimento Sustentável: O desafio do século XXI. Rio de Janeiro: Garamond, 2008.

YAMIN, Shahid et al. Relationship Between Generic Strategies, Competitive Advantage and Organizational Performance: An Empirical Analysis. Technovation. v.19.ano1999. p.507-518.

ZACARELLI, Sérgio B; FISCHMAN, Adalberto A. Estratégias Genéricas: Classificação e Usos. Revista de Administração de Empresas. v.34.n.4.13-22.

WHEELWRIGHT, Steven C. HAYES, Robert H. Competindo através da fabricação. Harvard Business Review. Jan.fev.1985. 
ANEXO I - Relação de automóveis comerciais e leves vendidos por tipo de combustível.

Tabela 6- Relação de automóveis comerciais e leves vendidos por tipo de combustível.

\begin{tabular}{|c|c|c|c|c|}
\hline \multirow[b]{2}{*}{ MESES } & \multicolumn{3}{|c|}{ AUTOMÓVEIS E COMERCIAIS LEVES } & \multirow{2}{*}{ TOTAL } \\
\hline & GASOLINA & ÁLCOOL & FLEX-FUEL & \\
\hline 1990 & 542.855 & 81.996 & - & 624.851 \\
\hline 1991 & 546.258 & 150.982 & - & 697.240 \\
\hline 1992 & 498.927 & 195.503 & - & 694.430 \\
\hline 1993 & 764.598 & 264.235 & - & 1.028 .833 \\
\hline 1994 & 1.127 .485 & 141.834 & - & 1.269 .319 \\
\hline 1995 & 1.557 .674 & 40.706 & - & 1.598 .380 \\
\hline 1996 & 1.621 .968 & 7.647 & - & 1.629 .615 \\
\hline 1997 & 1.801 .688 & 1.120 & - & 1.802 .808 \\
\hline 1998 & 1.388 .734 & 1.224 & - & 1.389 .958 \\
\hline 1999 & 1.122 .229 & 10.947 & - & 1.133 .176 \\
\hline 2000 & 1.310 .479 & 10.292 & - & 1.320 .771 \\
\hline 2001 & 1.412 .420 & 18.335 & - & 1.430 .755 \\
\hline 2002 & 1.283 .963 & 55.961 & - & 1.339 .924 \\
\hline 2003 & 1.152 .463 & 36.380 & 48.178 & 1.237 .021 \\
\hline 2004 & 1.077 .945 & 50.949 & 328.379 & 1.457 .273 \\
\hline 2005 & 697.004 & 32.357 & 812.104 & 1.541 .465 \\
\hline 2006 & 316.561 & 1.863 & 1.430 .334 & 1.748 .758 \\
\hline 2007 & 245.660 & 107 & 2.003 .090 & 2.248 .857 \\
\hline 2008 & 217.021 & 84 & 2.329 .247 & 2.546 .352 \\
\hline 2009 & 221.709 & 70 & 2.652 .298 & 2.874.077 \\
\hline
\end{tabular}


APÊNDICE 1 - Penetração do Etanol em relação a gasolina no período de 2000 a 2009.

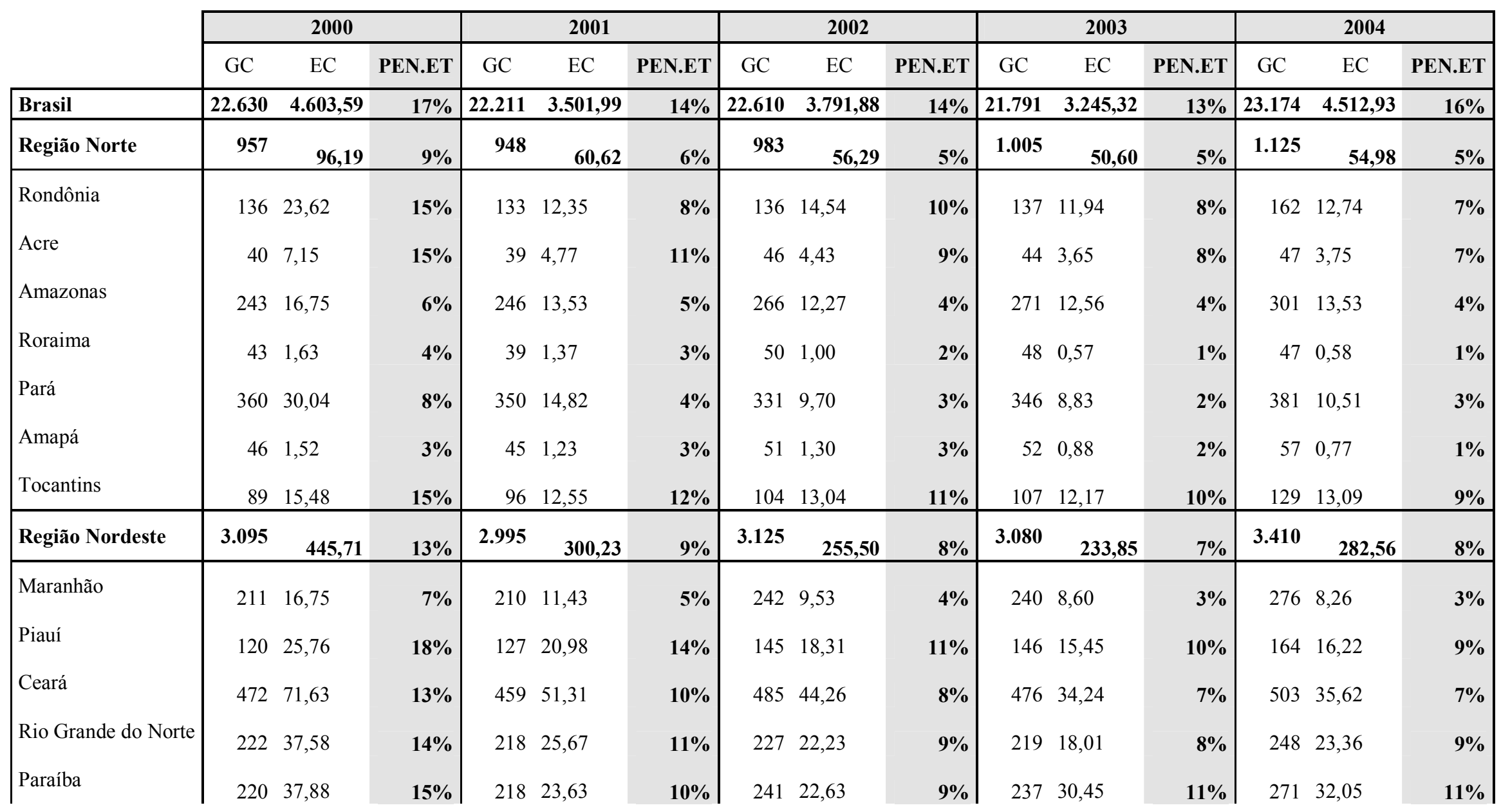




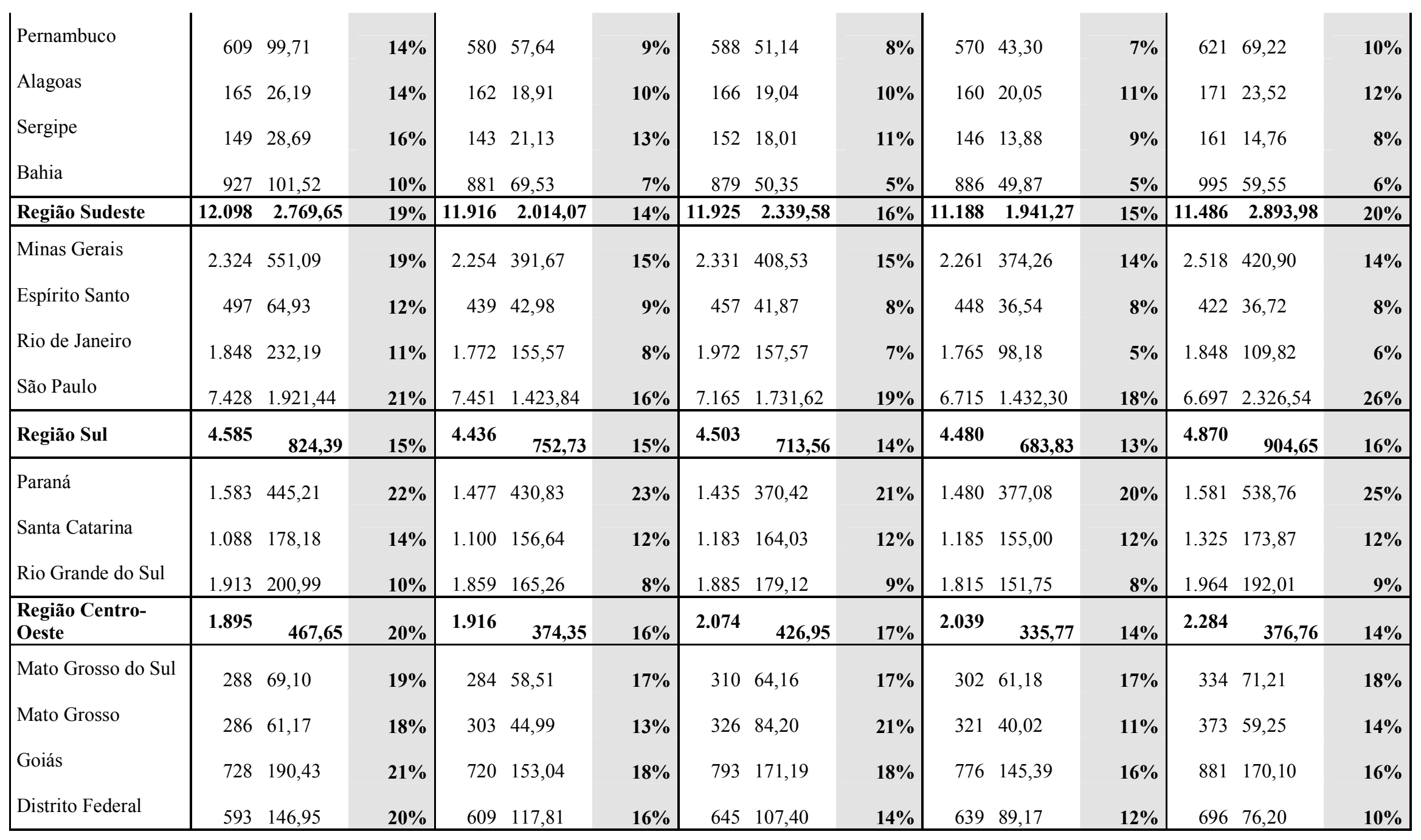




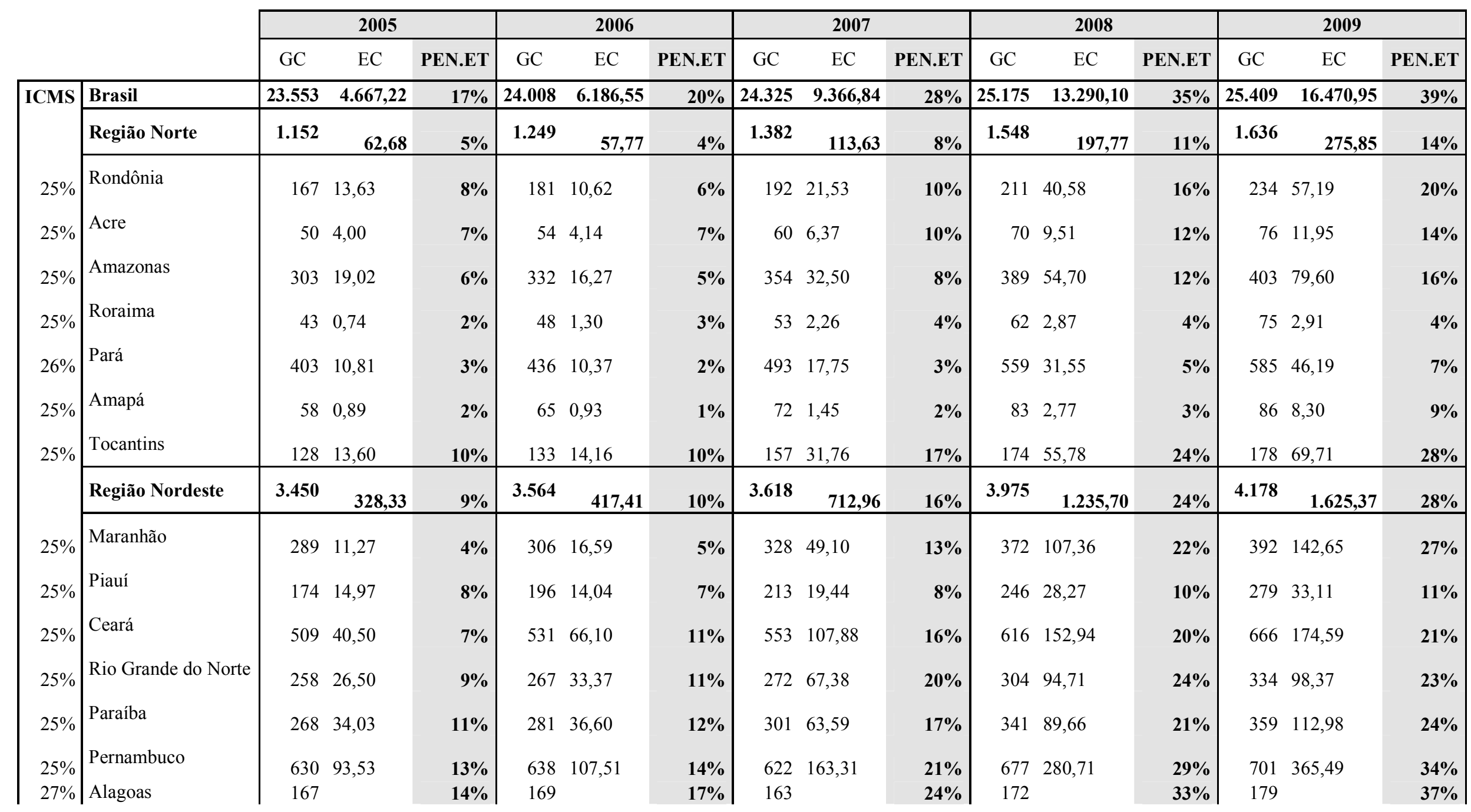




\begin{tabular}{|c|c|c|c|c|c|c|c|c|c|c|c|c|c|c|c|c|}
\hline \multirow{2}{*}{$27 \%$} & \multirow{3}{*}{$\begin{array}{l}\text { Sergipe } \\
\text { Bahia }\end{array}$} & \multicolumn{3}{|c|}{26,90} & \multicolumn{3}{|c|}{34,90} & \multicolumn{3}{|c|}{51,46} & \multicolumn{3}{|c|}{83,10} & \multicolumn{3}{|c|}{104,51} \\
\hline & & 163 & 13,52 & $8 \%$ & 171 & 12,77 & $7 \%$ & 176 & 16,85 & $9 \%$ & 197 & 29,43 & $13 \%$ & 210 & 52,50 & $20 \%$ \\
\hline \multirow[t]{2}{*}{$19 \%$} & & 993 & 67,11 & $6 \%$ & 1.006 & 95,53 & $9 \%$ & 989 & 173,95 & $15 \%$ & 1.050 & 369,51 & $26 \%$ & 1.056 & 541,17 & $34 \%$ \\
\hline & Região Sudeste & 11.686 & 3.023,31 & $21 \%$ & 11.862 & 4.381,77 & $27 \%$ & 12.092 & $6.578,10$ & $35 \%$ & 12.047 & $9.022,76$ & $43 \%$ & 11.853 & $10.860,08$ & $48 \%$ \\
\hline $25 \%$ & Minas Gerais & 2.580 & 391,48 & $13 \%$ & 2.698 & 371,41 & $12 \%$ & 2.828 & 602,74 & $18 \%$ & 2.925 & 957,20 & $25 \%$ & 3.008 & $1.204,43$ & $29 \%$ \\
\hline $27 \%$ & Espírito Santo & 431 & 50,55 & $10 \%$ & 462 & 42,43 & $8 \%$ & 475 & 70,83 & $13 \%$ & 485 & 137,25 & $22 \%$ & 511 & 172,83 & $25 \%$ \\
\hline $24 \%$ & Rio de Janeiro & 1.739 & 180,53 & $9 \%$ & 1.661 & 224,25 & $12 \%$ & 1.635 & 359,40 & $18 \%$ & 1.616 & 677,06 & $30 \%$ & 1.637 & 872,81 & $35 \%$ \\
\hline \multirow[t]{2}{*}{$12 \%$} & São Paulo & 6.935 & $2.400,75$ & $26 \%$ & 7.042 & $3.743,68$ & $35 \%$ & 7.154 & $5.545,12$ & $44 \%$ & 7.020 & $7.251,25$ & $51 \%$ & 6.697 & $8.610,00$ & $56 \%$ \\
\hline & Região Sul & 4.984 & 883,41 & $15 \%$ & 5.023 & 872,40 & $15 \%$ & 4.946 & $1.163,95$ & $19 \%$ & 5.198 & $1.605,38$ & $24 \%$ & 5.301 & $2.094,71$ & $28 \%$ \\
\hline $18 \%$ & Paraná & 1.724 & 518,24 & $23 \%$ & 1.646 & 520,58 & $24 \%$ & 1.639 & 701,25 & $30 \%$ & 1.700 & 904,33 & $35 \%$ & 1.604 & $1.193,03$ & $43 \%$ \\
\hline $25 \%$ & Santa Catarina & 1.353 & 175,27 & $11 \%$ & 1.479 & 193,06 & $12 \%$ & 1.339 & 242,40 & $15 \%$ & 1.376 & 376,16 & $21 \%$ & 1.452 & 498,65 & $26 \%$ \\
\hline \multirow[t]{2}{*}{$25 \%$} & Rio Grande do Sul & 1.907 & 189,90 & $9 \%$ & 1.898 & 158,76 & $8 \%$ & 1.967 & 220,30 & $10 \%$ & 2.122 & 324,89 & $13 \%$ & 2.246 & 403,03 & $15 \%$ \\
\hline & \begin{tabular}{|l|}
$\begin{array}{l}\text { Região Centro- } \\
\text { Oeste }\end{array}$ \\
\end{tabular} & 2.281 & 369,50 & $14 \%$ & 2.310 & 457,19 & $17 \%$ & 2.289 & 798,20 & $26 \%$ & 2.407 & $1.228,50$ & $34 \%$ & 2.440 & $1.614,95$ & $40 \%$ \\
\hline $25 \%$ & Mato Grosso do Sul & 319 & 71,59 & $18 \%$ & 319 & 65,29 & $17 \%$ & 329 & 105,47 & $24 \%$ & 356 & 166,28 & $32 \%$ & 373 & 207,98 & $36 \%$ \\
\hline $25 \%$ & Mato Grosso & 373 & 70,98 & $16 \%$ & 365 & 72,47 & $17 \%$ & 348 & 107,20 & $24 \%$ & 356 & 276,85 & $44 \%$ & 355 & 393,94 & $53 \%$ \\
\hline $20 \%$ & Goiás & 879 & 149,38 & $15 \%$ & 890 & 238,58 & $21 \%$ & 880 & 435,31 & $33 \%$ & 922 & 610,59 & $40 \%$ & 951 & 773,68 & $45 \%$ \\
\hline $20 \%$ & Distrito Federal & 711 & 77,56 & $10 \%$ & 736 & 80,86 & $10 \%$ & 732 & 150,22 & $17 \%$ & 773 & 174,78 & $18 \%$ & 762 & 239,35 & $24 \%$ \\
\hline
\end{tabular}

